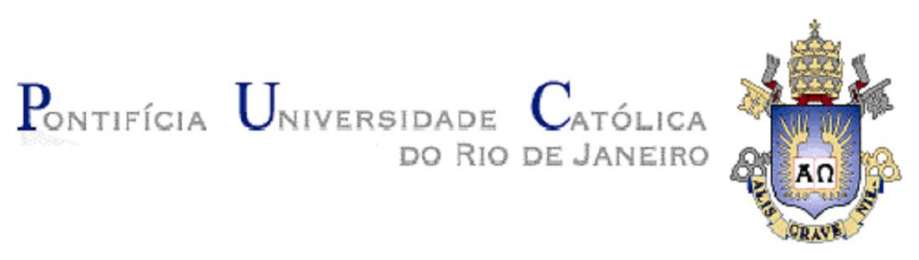

Ana Carolina Brasil de Oliveira

\title{
A penetração da educação ambiental crítica nos artigos publicados na ANPEd.
}

Orientador: Prof. Ralph Ings Bannell

Dissertação apresentada como requisito parcial para obtenção do grau de Mestre pelo Programa de PósGraduação em Educação do Departamento de Educação do Centro de Teologia e Ciências Humanas da PUC-Rio.

Rio de Janeiro

Junho de 2015 


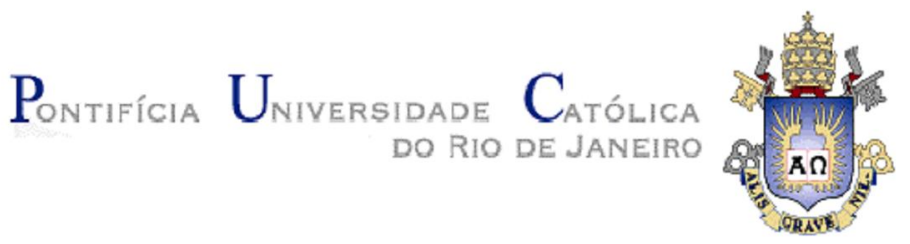

Ana Carolina Brasil de Oliveira

\title{
A penetração da educação ambiental crítica nos artigos publicados na ANPEd
}

Dissertação apresentada como requisito parcial para obtenção do grau de Mestre pelo Programa de PósGraduação em Educação do Departamento de Educação do Centro de Teologia e Ciências Humanas da PUC-Rio. Aprovada pela Comissão Examinadora abaixo assinada.

\author{
Prof. Ralph Igns Bannell \\ Orientador \\ Departamento de Educação - PUC-Rio
}

Profa. Hedy Silva Ramos de Vasconcellos

Departamento de Educação - PUC-Rio

Profa. Anice Esteves Afonso Departamento de Educação - UERJ

Prof ${ }^{a}$. DENISE BERRUEZO PORTINARI Coordenadora Setorial do Centro de Teologia e Ciências Humanas PUC-Rio

Rio de Janeiro, 9 de junho de 2015. 
Todos os direitos reservados. É proibida a reprodução total ou parcial do trabalho sem autorização da universidade, da autora e da orientadora.

\section{Ana Carolina Brasil de Oliveira}

Graduou-se em Geografia na Faculdade de Formação de Professores da Universidade do Estado do Rio de Janeiro em 2010. É especialista em Organização curricular e prática docente na Educação básica pela Faculdade de Educação da Baixada Fluminense da Universidade do Estado do Rio de Janeiro.

Ficha Catalográfica

Oliveira, Ana Carolina Brasil de

A penetração da educação ambiental crítica nos artigos publicados na ANPEd / Ana Carolina Brasil de Oliveira ; orientador: Ralph Ings Bannell. - 2015.

99 f. ; $30 \mathrm{~cm}$

Dissertação (mestrado)-Pontifícia Universidade Católica do Rio de Janeiro, Departamento de Educação, 2015.

Inclui bibliografia

1. Educação - Teses. 2. Educação ambiental crítica. 3. ANPEd. 4. Epistemologia ambiental. I. Bannell, Ralph Ings. II. Pontifícia Universidade Católica do Rio de Janeiro. Departamento de Educação. III. Título. 


\section{Agradecimentos}

É chegado o momento tão aguardado deste trabalho. Durante muitas noites ao longo do desenvolvimento dessa pesquisa eu sempre ensaiava mentalmente os meus agradecimentos. Isso reflete o meu comportamento, exagerado às vezes, de mostrar toda a gratidão que sinto pelos que me cercam. Se esse comportamento é bom ou ruim, não sei, só sei que nossa personalidade se molda a partir das nossas experiências, e, diga-se de passagem, sou muito feliz com as minhas. Não seguirei uma ordem de importância para tecer meus agradecimentos. Também tenho total clareza de que é impossível mencionar todas as pessoas que de alguma forma contribuíram nessa empreitada. Agora, sem me prolongar mais darei início ao reconhecimento daqueles que me ajudaram a chegar até aqui.

Agradeço ao meu orientador, Ralph, pela imensurável contribuição à minha formação acadêmica. Agradeço também pela sua paciência e compreensão com as dificuldades que apareceram no meio do caminho. Admiro muito a sua coerência e fico muito feliz de ter um orientador que defende os animais. Aprendi muito, pretendo continuar aprendendo, seja na universidade ou no facebook. Muito obrigada, Ralph!

Ao CNPq e à PUC - Rio, pelos auxílios concedidos sem os quais este trabalho não poderia ter sido realizado.

Agradeço ao meu ex marido Vinicius Seabra por toda contribuição acadêmica, pelos diálogos travados a cada jantar, pela paciência e pelo forte incentivo para que eu me dedicasse ao mestrado.

Agradeço aos meus pais biológicos Kátia e Sérgio por terem escolhido a melhor família do mundo pra me criar. Obrigada também por me darem a possibilidade de desfrutar de um momento tão prazeroso que é aprender.

Agradeço à minha mãe Dirce por todo seu amor e dedicação comigo. Obrigada por cada castigo, por cada briga na hora de ir pra escola e por todo sacrifício feito pra me dar uma vida feliz. Muito obrigada, mamãe.

Agradeço ao meu pai Luiz, ainda que sua participação na minha vida tenha sido tardia, agradeço principalmente por acreditar em mim. Você foi fundamental na minha formação.

Agradeço às minhas irmãs Marta, Heloisa, Joyce e Cláudia que durante toda a minha vida sempre fizeram tudo aquilo que podiam pra me dar uma boa 
educação e me fazer feliz. Obrigada especialmente à minha irmã e madrinha Cláudia por acompanhar até o último minuto o desenvolvimento deste trabalho. Nossas conversar diárias pelo telefone todas as noites sempre me acalmaram e me faziam acreditar que eu conseguiria dar mais um passo. Deco e Diniz, vocês também foram muito importantes na minha trajetória.

Agradeço aos meus sobrinhos Amanda, Brenda, Mariana, Vitória, Vitor e Bruno por adoçarem a minha vida e tornar esse momento mais feliz.

Agradeço aos meus primeiros orientadores Andrelino Campos e Tamara Egler por toda torcida e pelo conhecimento que me ofereceram. Agradeço com muito carinho aos membros do Laboratório Espaço, coordenado pela Tamara, principalmente aos meus companheiros Aldenilson, Natália e Mabel.

À minha orientadora da especialização Maria Lúcia Kalaf que contribui muito na minha inserção no mestrado, bem como no meu contato com Leff.

Agradeço a todos os professores do departamento de educação da PUC que pude dialogar durante o mestrado. Também agradeço aos funcionários da secretaria, sobretudo à Nancy que sempre foi solicita e me ajudou em momentos difíceis na solução de problemas burocráticos que envolvem a pesquisa científica.

Aos meus companheiros de graduação que sempre se dispuseram a ampliar os debates acadêmicos. Taís, Caroline, Gilmara, Felipe, Marlon e Ísis, obrigada.

Agradeço de todo o coração às minhas gatinhas Felícia e Luna. Elas contribuíram muito na produção do meu trabalho. Sempre ao meu lado, elas tornaram os momentos cansativos em horas de alegria. Felícia e Luna foram fundamentais na transformação do meu pensamento acerca dos animais. Elas também contribuíram muito para que o meu discurso se alinhasse à minha prática. O pensamento de que o homem é superior à natureza foi desconstruído graças a elas e as leituras que eu desenvolvi.

Agradeço aos amigos Patrícia e Rafael Xavier pela amizade, por me apresentarem novos autores, pelos empréstimos de livros e pela possibilidade de um diálogo na Universidade Estadual da Paraíba.

Agradeço às minhas amigas Paula Fernanda e Mariana Caruso por toda ajuda dispensada na realização do meu trabalho. Obrigada também pelo amor e carinho que vocês sempre tiveram comigo. Mariana foi fundamental nos meus primeiros passos na discussão ambiental. 
Agradeço aos meus amigos de turma de mestrado, em especial à Camila Souza e Rafael Ventura pelo companheirismo nesses dois anos.

Agradeço de antemão aos membros da banca que aceitaram participar na avaliação do meu trabalho. Um agradecimento em especial à professora Anice e Otávio por participarem da minha formação acadêmica. Obrigada a todos. 


\section{Resumo}

Oliveira, Ana Carolina Brasil de.; Bannell, Ralph Ings. A penetração da educação ambiental crítica nos artigos publicados na ANPEd. Rio de Janeiro, 2015. 99p. Dissertação de Mestrado - Departamento de Educação, Pontifícia Universidade Católica do Rio de Janeiro.

O presente trabalho teve por objetivo analisar a penetração da educação ambiental crítica nos artigos publicados na ANPEd - Associação Nacional de Pós-Graduação e Pesquisa em Educação - nos períodos entre 2005 e 2013. Para chegar ao objetivo da pesquisa, os trabalhos publicados no período citado acima, foram classificados de acordo com seu eixo temático. Ao todo, foram identificados 27 eixos temáticos, sendo a maior parte dos trabalhos inseridos no eixo intitulado educação ambiental crítica. Dessa forma privilegiou-se a análise do mesmo. O referencial teórico foi construído a partir do trabalho de Henrique Leff. A metodologia utilizada na presente análise foi construída a partir das proposições de L. Bardin, tratando-se portando de uma análise qualitativa construída por meio da análise de conteúdo.Quanto aos resultados foi possível notar que os artigos analisados se apresentam de maneira crítica segundo as categorias de análise que foram utilizadas bem como a compatibilidade do referencial teórico adotado. Os artigos se mostraram coerentes não havendo contradições em seus discursos proferidos. Entretanto algumas limitações na produção intelectual investigada puderam ser identificadas. Dentre essas limitações podemos destacar a falta de diálogo com os clássicos do campo da educação ambiental, bem como a falta de profundidade nas discussões de alguns conceitos.

\section{Palavras-chave}

Educação ambiental crítica; ANPEd; Epistemologia ambiental. 


\section{Abstract}

Oliveira, Ana Carolina Brasil de.; Bannell, Ralph Ings. (Advisor) The penetration of critical environmental education in articles published in ANPEd. Rio de Janeiro, 2015. 99p. MSc. Dissertation - Departamento de Educação, Pontifícia Universidade Católica do Rio de Janeiro.

This study aimed to analyze the penetration of critical environmental education in articles published in ANPEd - National Association of Graduate Studies and Research in Education - in the period between 2005 and 2013. To reach the goal of the research work published in the period cited above were classified according to its theme axis. In all, 27 themes were identified, most of the works entered in the axis entitled critical environmental education. Thus it focused on the analysis of it. The theoretical framework was built from the Henry Leff work. The methodology used in this analysis was built from the propositions of Bardin, in the case of carrying a qualitative analysis built through content analysis. As for the results it was noticeable that the articles analyzed are presented critically by category of analysis that were used as well as the compatibility of the theoretical framework adopted. Articles proved consistent with no contradictions in their speeches. However some limitations in intellectual production investigated could be identified. Among these limitations we can highlight the lack of dialogue with the classics of the environmental education field as well as the lack of depth in discussions of concepts.

\section{Keywords}

Environmental education critical; ANPEd; Environmental epistemology. 


\section{Sumário}

1. Introdução 12

1.1. Trajetória de uma pesquisa 12

1.2. Contextualizando o problema 14

$\begin{array}{ll}\text { 1.3. Aproximando o campo de estudo } & 17\end{array}$

2. Referencial teórico 23

2.1 Movimento da Educação Ambiental 23

2.2 Pressupostos teóricos da Educação Ambiental Crítica 25

2.2.1a Dialética em Marx 26

2.3 Epistemologia ambiental 29

2.3.1a Questão ambiental 31

2.3.2 Ambiente e objeto científico transdiciplinar 33

2.3.3 Racionalidade Ambiental $22 \quad 33$

2.3.4 O Conceito dee Racionalidade Ambiental 34

2.3.5 Saber ambiental $\quad 35$

2.4 O Conceito de Natureza 36

2.4.1 A Ciência diante da Natureza 38

2.4.2 A oposição Homem versus Natureza 38

2.4.3 A oposição Sujeito versus Objeto 40

2.4.4 O paradigma atomístico-individualista da ciência moderna 41

2.4.5 A Harmonia Natural 42

2.4.6 O conceito de Ecossistema 42

2.4.7 O homem na Natureza e a Natureza do homem 43

3. Metodologia 45

3.1 Eixos temáticos 51

3.2 Categorias de análise 55

3.3 Análise dos artigos 58

4. Resultados 84

5. Conclusões 94

6. Referências Bibliográficas $\quad 97$ 


\section{Lista de Tabelas}

Tabela 1 - Número de trabalhos publicados na ANPED 48

Tabela 2 - Número de trabalhos publicados por eixo temático 50

Tabela 3 - Artigos classificados segundo as categorias de análise $\quad 78$ 


\section{Lista de Figuras}

Figura 1 - Análise desenvolvida por Bardin $\quad 47$

Figura 2 - Caminhos desenvolvidos para a elaboração do trabalho 


\section{1.}

\section{Introdução}

\section{1.}

\section{Trajetória de uma pesquisa}

Minha formação acadêmica teve início em 2006 com a minha inserção no curso de Licenciatura em Geografia na Faculdade de Formação de Professores da Universidade do Estado do Rio de Janeiro. Dentre as razões que motivaram a escolha do curso de geografia, duas destacam-se: O desejo de ser professora, e a necessidade de compreender a espacialização de alguns fenômenos observáveis nos grandes centros urbanos, com destaque aos processos de exclusão e segregação sócio-espacial além dos problemas ambientais. Dessa forma, a aprovação no vestibular significou um primeiro caminho que me levou para os estudos espaciais incluindo os de natureza ambiental.

Ainda no início do curso de Geografia da Faculdade de Formação de Professores da Universidade do Estado do Rio de Janeiro me interessei pela pesquisa desenvolvida pelo grupo de estudos NOSER- Núcleo de Estudos Sociedade, Espaço e Raça - UERJ/ FFP coordenado pelo professor Dr. Andrelino de Oliveira Campos, onde tive a oportunidade de ser aceita como bolsista de Iniciação Cientifica. A participação neste grupo despertou meu interesse na participação com atividades de pesquisa cientifica.

Em 2008, além da experiência com a questão urbana, tive a oportunidade de participar do projeto de pesquisa Educação do campo, coordenado pelo professor Paulo Raposo Alentejano da UERJ/ FFP. Dentre os diferentes projetos desenvolvidos pelo professor, participei do intitulado "Educação do Campo". A questão que norteava o projeto consistia em elaborar uma nova metodologia de ensino que atendesse às reais demandas dos estudantes das escolas localizadas no assentamento Engenho Novo, localizado em Monjolos-SG. Dessa maneira, o ensino básico para os estudantes inseridos nas áreas rurais deveria ser ministrado respeitando a realidade desses sujeitos.

Em abril de 2009 ingressei como Bolsista de Iniciação Científica no Laboratório Estado, Sociedade, Tecnologia e Espaço do Instituto de Pesquisa e Plenejamento Urbano e Regional da Universidade Federal do Rio de Janeiro coordenado pela professora Tamara Egler, e onde permaneci até o ano de 2012. 
A questão por mim desenvolvida no laboratório referia-se aos processos de inclusão e exclusão social na cidade de Piraí. A questão central da pesquisa consistia em verificar os efeitos das novas tecnologias de informação e comunicação nos processos de inclusão social.

A partir de Março de 2010 passei a lecionar Geografia para turmas de $6^{\circ}$ ao $8^{\circ}$ (Ensino Fundamental II) no colégio Percepção e do $1^{\circ}$ ao $3^{\circ}$ ano (Ensino Médio) no colégio João Lyra Filho, e em 2011 fui inserida no quadro de docentes do colégio Paula Barros, lecionando Geografia para alunos do ensino médio.

Ainda em 2011, fui indicada como bolsista do projeto Redes de Políticas Públicas para Educação do Projeto Observatório da Educação no Instituto de Pesquisa e Planejamento Urbano e Regional - IPPUR/ UFRJ, coordenado pela Prof $^{\circ}$ Dr Tamara Tania Cohen Egler e financiado pelo CNPq. A inserção no referido projeto, além da minha experiência enquanto docente levou-me a buscar o curso de Especialização em educação para que eu pudesse ter subsídios para desenvolver um bom relatório de pesquisa e compreender os dilemas da educação brasileira.

Dessa forma, em 2011 ingressei como aluna do curso de especialização intitulado "Organização curricular e prática docente na educação básica" da Faculdade de Educação da Baixada Fluminense - UERJ/ FEBF.

Em 2012 fui aprovada para ingressar o quadro de discentes do curso de mestrado em Educação brasileira da Pontifícia Universidade Católica do Rio de Janeiro. Ao ingressar no mestrado, novas possibilidades de pesquisa se abriram o que me fez chegar ao tema da Educação Ambiental. Conforme já mencionei, na minha experiência de aluna de iniciação científica as novas tecnologias de informação e comunicação se apresentavam como meu objeto de estudo. Entretanto, no mestrado, com novas leituras, pude perceber que embora muito importantes, as novas tecnologias de informação e comunicação ainda não fazem parte da realidade de grande parte dos brasileiros que ainda se mantém excluídos do acesso à tecnologia. Sendo assim, pude notar através de hipóteses por mim elaboradas, que a mídia de massa era a grande responsável pela formação de opiniões principalmente dos jovens. Ao mesmo tempo, a minha experiência docente me fez perceber o quanto os alunos eram levados por pseudo-verdades que a mídia de massa construía acerca do meio ambiente. Sendo assim, no meu projeto de mestrado resolvi pesquisar o discurso da mídia acerca do meio 
ambiente. Em decorrência do curto tempo para desenvolver a pesquisa que requeria uma análise do discurso, resolvi focar meu trabalho apenas na educação ambiental analisando a penetração da perspectiva crítica da educação ambiental nos trabalhos publicados na Anped.

\section{2.}

\section{Contextualizando o problema}

De acordo com Boff (2012), há poucas palavras mais usadas hoje do que o substantivo sustentabilidade e o adjetivo sustentável. Atualmente podemos notar uma apropriação exacerbada de tal termo seja pelas grandes corporações, seja pelos governos ou ainda pela mídia. Tal apropriação deve ser vista por dois diferentes prismas. $\mathrm{O}$ primeiro se refere ao discurso do medo produzido pela mídia no que se refere às questões ambientais. O segundo como um ponto de partida para problemas de fato existentes herdados da idade da razão, da racionalidade técnica e ampliado a partir do modelo neoliberal nos últimos 40 anos. Dentre os problemas ambientais podemos citar a poluição das águas, poluição do ar, erosão de solos, a extinção de espécies da fauna e da flora, o problema do lixo, além do temido aquecimento global. Para Gonçalves (2013) com a questão ambiental estamos diante de questões de claro sentido ético, filosófico e político. Nesse sentido o autor questiona quais são os limites da relação da humanidade com o planeta? Que destinos dar à natureza?

Leff (2009) destaca que a racionalidade econômica que se instaura no mundo como o núcleo duro da racionalidade da Modernidade, se expressa em um modo de produção fundado no consumismo que destrói a natureza. Afirma ainda que o capital alcançou um determinado nível de desenvolvimento o que faz com que para sua reprodução ampliada sejam necessárias novas fontes de acumulação que the permitem ampliar as taxas de mais-valia. Para o autor esse processo promove a apropriação dos recursos naturais dos países tropicais o que resulta num processo de subdesenvolvimento como resultado da divisão internacional do trabalho, a troca desigual de mercadorias e a degradação ambiental gerados no processo de globalização do capital.

Sendo assim, o autor nos informa que a desigualdade entre países ricos e pobres não surge só de uma divisão desigual da riqueza, mas que gera também a sobre-exploração dos recursos naturais e da força de trabalho. 
Este processo de espoliação e exploração implica a destruição da base de recursos naturais e culturais dos países pobres, que poderiam usá-la para seu desenvolvimento endógeno. (LEFF, 2009 p. 28)

Dessa forma o autor atribui às diferenças entre países pobres e ricos para os problemas ambientais. Assinala ainda que desde o seu começo, o processo de acumulação do capital impôs a necessidade de expandir suas fronteiras para a exploração de seus recursos e da sua força de trabalho, sendo o auge do capitalismo mercantil decisivo na destruição e transformação das civilizações dos trópicos. Leff (2009) vai afirmar ainda que a exploração dos recursos dos países do Terceiro Mundo foi gerando danos irreversíveis em seus ecossistemas naturais. Destaca também que com relação aos ecossistemas tropicais (caracterizado pela grande diversidade de espécies), sua transformação em campos de cultura alterou seu equilíbrio e resiliência, tornando-os mais suscetíveis a catástrofes naturais.

Leff (2008) vai dizer que o princípio de sustentabilidade surge no contexto da globalização como a marca de um limite e o sinal que reorienta o processo civilizatório da humanidade. Para este autor, a crise ambiental veio questionar os paradigmas e a racionalidade que impulsionaram e legitimam o crescimento econômico, negando a natureza. Sobre estes paradigmas podemos destacar a visão mecanicista da razão cartesiana.

A visão mecanicista da razão cartesiana converteu-se no princípio constitutivo de uma teoria econômica que predominou sobre os paradigmas organicistas dos processos da vida, legitimando uma falsa idéia de progresso da civilização moderna (LEFF, 2008 p.15)

A crise econômica se torna ainda mais evidente nos anos 60 com o questionamento aos padrões de consumo e de produção, marcando os limites para o crescimento econômico.

Para Gonçalves (2013), estamos ainda muito distantes das respostas que nos são oferecidas pelo ecologismo. Nas palavras do autor:

Como se vê, estamos muito longe das respostas à La carte que nos são oferecidas por um ecologismo ingênuo, embora muitas vezes bem-intencionado, que a mídia manipula sabiamente, convidando-nos a cuidar do lixo nosso de cada dia ou daquela espécie que está ameaçada. Faça sua parte, convidam-nos, como se a parte de cada um na injustiça ambiental que impera no mundo fosse semelhante à de todos; como se o todo fosse a soma das partes. (GONÇALVES, 2013 p. 17).

A partir da citação acima fica claro a existência de perspectivas ambientais que ainda atribuem os efeitos da problemática ambiental aos indivíduos e não aos 
verdadeiros responsáveis ${ }^{1}$ pelos danos ambientais no planeta. Talvez essa seja uma das respostas para o hiato existente entre as teorias da educação ambiental e as ações efetivas das práticas propostas. Nesse sentido, verifica-se a necessidade de ampliar e aprofundar o debate da educação ambiental numa perspectiva crítica que rompa com as visões hegemônicas e reducionistas de mundo, a fim de promovermos mudanças efetivas e a produção de um mundo verdadeiramente sustentável. Dessa forma, o principal objetivo do presente trabalho é verificar a penetração da teoria crítica da educação ambiental nos trabalhos publicados na ANPED no GT 22 de educação ambiental.

É inegável a crise ambiental na qual estamos inseridos. Leff, afirma que mais que uma crise passageira, estamos diante de uma crise civilizacional. Concordando com o autor, podemos perceber que são inúmeros os problemas ambientais contemporâneos. Enumerando rapidamente tais problemas, podemos destacar: a crise e poluição das águas, o desmatamento, a perda de biomassa, a erosão dos solos, a poluição do ar, os problemas referentes ao lixo, além do tão discutido aquecimento global. Entretanto, o aumento do número de problemas ambientais não têm sido compatíveis com as alternativas para solucioná-los. Isso em grande parte deve-se à buscas baseadas em técnicas e não na mudança de comportamentos. Tentar salvar o planeta por meio do racionalismo técnico que o destruiu é pelo menos contraditório. Nesse sentido, acreditamos que seja necessário buscar alternativas teóricas e práticas que sejam capazes de provocar transformações efetivas na sociedade.

A partir da Revisão da Literatura feita no banco de teses da Capes descrito no capítulo III, foi possível identificar que o número de trabalhos que objetivam compreender os problemas ambientais de forma crítica ainda é bem reduzido. Nesse sentido, torna-se importante investigar as abordagens que os trabalhos que se julgam críticos utilizam, uma vez que é a partir desse referencial teórico que projetos escolares deveriam ser elaborados, assim como políticas públicas de educação ambiental.

Sendo assim, o presente trabalho poderá oferecer uma contribuição no campo da Educação, no que se refere ao aporte teórico da Educação Ambiental enquanto possibilidade para a construção de trabalhos efetivamente críticos.

\footnotetext{
1 Refere-se ao capital personificado pelas grandes corporações como as multinacionais e indústrias.
} 


\section{3.}

\section{Aproximando o campo de estudo}

Para que fosse possível conhecer o campo no qual o presente trabalho se insere, inicialmente realizei uma pesquisa para compreender os contornos da Educação Ambiental no Brasil. Para isso realizei uma pesquisa no banco de teses da Capes seguindo os caminhos apontados no parágrafo a seguir.

Ao digitar a palavra Educação ambiental tendo como critério o resumo, no banco de teses da Capes, foram encontrados 1450 trabalhos publicados de 2010 até hoje. Para refinar a pesquisa, utilizei os trabalhos publicados na área de educação, o que diminuiu o número de trabalhos para 234. Refinando ainda mais a pesquisa, digitei as palavras educação ambiental crítica, o que resultou em 180 trabalhos. Delimitando ainda mais a pesquisa, escolhi os trabalhos da área da educação o que resultou em 85 trabalhos.

$\mathrm{Na}$ impossibilidade de analisar 85 trabalhos, escolhi o critério de busca avançada digitando as palavras educação ambiental/ crítica no campo título, o que resultou em 15 trabalhos que serão mostrados a seguir.

Maia (2011) desenvolve uma pesquisa que tem por objetivo construir coletivamente um projeto de educação ambiental na perspectiva sócio-histórica. Sendo assim, seu trabalho buscou por meio da metodologia pesquisa-ação, identificar os problemas sócio-ambientais presentes em uma escola pública. Como resultado, seu trabalho sugere que o desenvolvimento do projeto permitiu construir com os professores as estratégias para o enfrentamento das situações relacionadas à sua prática social e pedagógica.

Oliveira (2012) discute a importância da participação e da formação para a cidadania tendo por base a Educação Ambiental crítica como ferramenta para a mudança da sociedade antidemocrática subversiva ao capital financeiro. Foram investigadas as concepções de Educação Ambiental de dois grupos de educadores da Baixada Fluminense. Metodologicamente o trabalho contou com o uso de entrevistas, e observação das práticas dos educadores, além do estudo teórico fundado na teoria crítica em sua perspectiva histórico-dialética. Como resultado, foi possível notar a presença de concepções e práticas hegemônicas e visões ideologizadas de mundo. A pequena parcela de educadores que avançou para a tendência crítica, ainda assim apresentou práticas amarradas à perspectiva homogeneizante. 
Nunes (2012) analisa o programa de educação ambiental da companhia de Docas do Pará apresentando como objetivo a análise descritiva deste programa no terminal petroquímico de Miramar, relacionando-o com a política nacional de educação ambiental (lei n 9.795/ 99) e demais legislações importantes. Foi problematizada a efetivação da educação ambiental enquanto política pública. Metodologicamente foi utilizada a pesquisa documental a partir da análise descritiva dos relatórios de atividades do programa de educação ambiental no terminal petroquímico Miramar. Utilizou-se também como aporte teórico para a compreensão do objeto de estudo a perspectiva do materialismo histórico dialético relacionado com o conceito de educação ambiental crítica, emancipatória, popular e transformadora uma vez que o cenário encontrado foi de insalubridade ambiental decorrente de políticas de exploração desenfreada dos recursos naturais e ameaça à biodiversidade, biomas, ecossistemas e que repercutem no aumento das desigualdades socioambientais. Dessa forma, o autor conclui que o programa educação ambiental da companhia de Docas do Pará deve ser entendido como elemento de legitimação e efetivação da política nacional de educação ambiental, sendo esta política fruto de demandas sociais, que vem atender e revelar a face reformista e conservadora do Estado e do sistema capitalista em suas funções. Sendo assim, concluiu-se que apesar dos avanços nos debates do programa, o mesmo precisa enfatizar a necessidade de superação da realidade de crise socioambiental.

Kaplan (2011) com base nos referenciais teóricos-metodológicos do materialismo histórico-dialético da educação ambiental crítica, buscou analisar nos documentos referentes às principais políticas federais do campo da educação ambiental a política nacional de educação ambiental (lei n 9.795/ 99), o programa nacional de formação de educadores ambientais. A perspectiva do seu trabalho é de que não se deve separar o discurso da prática. Como resultado, pôde-se perceber que os discursos hegemônicos e oficiais analisados são expressão do contexto em que tais políticas são produzidas, ou seja, a reforma gerencial do Estado brasileiro iniciada em meados dos anos 1990 e definida pelo projeto político neoliberal.

Vasconcelos (2011) aborda a formação do sujeito ecológico e autônomo em um cenário de crise socioambiental mundial a partir da educação ambiental crítica, fundamentada nas concepções pedagógicas do educador Paulo Freire. Para 
Vasconcelos a educação ambiental crítica, transformadora, propõe a superação do falso dualismo entre reflexão e ação. Assim seu foco de estudo foi o educador como forma de contribuição direcionada especificamente para educadores foi feita a opção de produzir um portfólio com textos diversos abordando questões relacionadas com a causa ambiental, com a educação ambiental crítica e com vários temas vinculados à educação. Esse material foi avaliado por diversos educadores e, como resultado, constatou-se que há interesse dos educadores pela educação ambiental, mas ao mesmo tempo a necessidade de haver um processo contínuo de formação e a implementação de ações mais organizadas e concretas de educação ambiental no processo educativo escolar com vistas a aproveitar o potencial existente nesse meio para traduzir anseios e necessidades que estão postos pelas exigências do momento em toda sociedade.

Serrão (2012) desenvolveu uma pesquisa por meio de um estudo de caso sobre PEAs implementados por empresas de petróleo, tendo como contraponto os programas de responsabilidade social desenvolvidos por essas mesmas empresas. Seu referencial teórico baseou-se na concepção gramsciana de Estado ampliado que considera a sociedade civil como arena de disputas na construção da hegemonia e o materialismo histórico dialético foi adotado como perspectiva teórico-metodológica. Concluiu-se que tais processos educativos representam projetos democráticos em disputa na sociedade com o projeto neoliberal e, devido às limitações impostas por esse, os PEAs constituem-se como instrumentos de resistência à expansão intensiva dos recursos naturais e sociais.

Santos (2011) desenvolveu uma pesquisa que visa entender como o dilema consumo versus sustentabilidade é trabalhado em propagandas comerciais de TV ligadas ao mercado verde. Foram analisados três comerciais veiculados pela TV aberta. A intenção foi de revelar e colocar em discussão questões de ideologia presentes nestes discursos e contribuir para o debate da EA crítica. A segunda etapa do trabalho consistiu na criação de um roteiro para análises de comerciais em sala de aula. O roteiro foi trabalhado com os alunos, afim de verificarem a sua validade enquanto promotor de um debate crítico dos alunos com relação a apropriação da questão ambiental pela mídia. Concluiu-se que este recurso pode contribuir para uma leitura crítica deste mundo na perspectiva de escrevermos um mundo diferente no qual queremos viver. 
Ferreira (2012) aborda a utilização de temas socioambientais no ensino de matemática aplicada e desenvolvida numa escola localizada na zona oeste da cidade do Rio de Janeiro. A metodologia utilizada foi o estudo de caso. Nas atividades introduziram-se os conteúdos matemáticos de modo contextualizado, usando temas socioambientais e de forma a contribuir para a formação de cidadãos mais participativos, mais críticos e mais comprometidos com a questão ambiental. Como resultado foi possível perceber que os temas socioambientais contribuem para um melhor entendimento da matemática.

Gomes (2012) busca uma reflexão crítica do atual processo de desenvolvimento econômico instalado no municio do Rio Grande / RS. Foram utilizados métodos dedutivos e dialético por compreender-se mais coerente com a proposta dialógica. Os resultados mostraram novos olhares a cerca das percepções de mundo, busca pela emancipação dos sujeitos, além da vista da educação ambiental. Assim, os aspectos da EA sugerem ferramentas auxiliares e / ou alternativas, propondo a emancipação dos sujeitos, superando a utopia do desenvolvimento sustentável.

Garrido (2012) apresenta os resultados da pesquisa que investigou a percepção de meio ambiente por alunos do $1^{\circ}$ e $5^{\circ}$ anos do Ensino Fundamental. $\mathrm{O}$ estudo foi realizado em uma escola pública do município de Duque de Caxias. Os instrumentos utilizados foram a elaboração de desenhos, entrevistas e análise de gravuras. Os resultados mostraram que os alunos dos $1^{\circ}$ e $5^{\circ}$ anos possuem uma visão naturalista do meio ambiente.

Souza (2012) desenvolve um estudo que trata dos principais aspectos que constituem a EA em uma perspectiva crítica que venha romper com as visões simplistas que reduzem o meio ambiente ao verde e a natureza. Metodologicamente o trabalho contou com a pesquisa participante buscando fornecer subsídios para a prática docente.

Fonseca (2011) elaborou uma pesquisa que teve por objetivo refletir acerca dos conceitos e sobre a formação de valores e atitudes a partir do ensino e aprendizagem em uma perspectiva crítica sobre as questões socioambientais. Metodologicamente o trabalho foi estruturado numa base etnográfica com método de pesquisa participante. Como resultado, a pesquisa mostrou que com a intervenção ocorre uma mudança na maneira como o aluno interpreta o meio ambiente através de seus vários aspectos. 
Rohde (2012) mostra como os problemas ambientais se intensificaram com a sedentarização do homem e com a modificação da paisagem natural com o surgimento das cidades. Afirma também que com o crescimento das cidades aumentaram os problemas ambientais urbanos. Com esse padrão, aumentaram também os problemas do lixo, da poluição do ar, falta de saneamento, as moradias irregulares e, junto com esses problemas, crescem a preocupação com as questões ambientais. Dessa forma a educação ambiental se apresenta como uma alternativa para amenizar os danos causados pelo homem e de se educar a sociedade. O objetivo do seu trabalho consistiu em avaliar por meio de mapas mentais como alunos da $7^{\circ}$ série percebem os problemas ambientais urbanos. Dentre os principais problemas encontrados pelos alunos destaca-se o lixo. Sendo assim, exige-se um trabalho de educação ambiental emancipatória mais profundo voltado para esse problema, buscando alternativas conscientes não só para a reciclagem, mas também para uma outra postura em relação ao consumo.

Floriano (2011) desenvolveu uma proposta de EA baseada na pesquisaação-participativa em uma escola da Baixada Fluminense em Duque de Caxias. A pesquisa foi feita com base em um aporte teórico crítico com a participação dos alunos em todas as suas etapas. O centro da discussão foram as condições socioambientais de existência dos alunos e envolveu ainda a existência de uma unidade de conservação próxima à escola. Seu objetivo foi a construção de práticas de EA que transcendessem à reciclagem e os muros da escola. Como resultado o trabalho evidenciou que a EA praticada na escola tem caráter conservador e que a EA construída a partir de um tema gerador mostrou-se um caminho importante na busca de maior participação dos alunos e da comunidade escolar.

Para Singh (2012) a geografia como ciência social contribui para o processo de ensino-aprendizagem em todos os níveis da educação básica e procura formular e aprofundar a interação entre sociedade e natureza, analisando as modificações causadas ao meio ambiente. Para a autora a EA por ser uma ciência interdisciplinar pode-se valer da geografia. Seu trabalho foi desenvolvido no bairro de Estoril no distrito de Riacho Grande em São Bernardo do Campo, São Paulo, e teve por objetivo contribuir para a identificação das questões socioambientais vinculadas pelos alunos de São Bernardo em sua realidade espacial local. A proposta do trabalho buscou fazer com que os alunos 
desenvolvessem trabalhos sobre o bairro, ruas e escolas se identificando como agente social. Como resultado, o trabalho mostra que essas práticas despertaram a responsabilidade dos estudantes em relação aos cuidados com essas áreas e com a multiplicação desses conhecimentos para as gerações futuras.

Para finalizar o presente capítulo, destaco que a minha aproximação com o campo da Educação Ambiental se deu a partir da minha experiência e formação inicial. O exercício de aproximação com o referido campo foi fundamental para que eu compreender as demandas atuais da área, bem como para orientar o caminho escolhido na realização da presente pesquisa. No próximo capítulo será apresentada a fundamentação teórica que orienta a produção deste trabalho.

O próximo capítulo tem início com uma discussão que visa à compreensão do movimento da Educação Ambiental. Num segundo momento serão apresentados os pressupostos teóricos do quem vem a ser uma educação ambiental crítica. Posteriormente apresentarei as concepções de Leff, principal referência utilizada no trabalho. Diante da complexidade de alguns conceitos e idéias utilizadas por Leff, busquei me concentrar na obra intitulada Epistemologia ambiental, seguindo a mesma ordem que o autor e utilizando os seus subtítulos. Paralelamente recorri a outros livros do mesmo autor e de outros. 


\section{2. \\ Referencial teórico}

\section{1. \\ Movimento da educação ambiental}

Segundo Gonçalves (2013), a década de 60 marca a emergência, no plano político, de uma série de movimentos sociais, dentre os quais o ecológico. Sendo assim, a década de 60 assistirá, portanto, ao crescimento de movimentos que não criticam exclusivamente o modo de produção, mas, fundamentalmente, o modo de vida Gonçalves (2013).

Na perspectiva do movimento ecológico, Gonçalves nos diz que:

(...) veremos o desenvolvimento de lutas em torno de questões das mais diversas: extinção de espécies, desmatamento, uso de agrotóxicos, urbanização desenfreada, explosão demográfica, poluição do ar e da água, contaminação de alimentos, erosão dos solos, diminuição de terras agricultáveis pela construção de grandes barragens, ameaça nuclear, guerra bacteriológica, corrida armamentista, tecnologias que afirmam a concentração do poder, entre outras. Não há, praticamente, setor do agir humano onde ocorram lutas e reinvindicações que o movimento ecológico não seja capaz de incorporar. (GONÇALVES, 2013 p. 12)

O movimento ecológico no Brasil surge na década de 70 , no contexto marcado pela ditadura militar, o que impossibilitava a construção de uma educação ambiental transformadora. Gonçalves (2013) vai nos dizer que é sob a égide do capital internacional que o Brasil vai alcançar o maior desenvolvimento industrial de sua história, alertando ainda que tal desenvolvimento se fazia ainda num país onde as elites dominantes não tinham por tradição respeito pela natureza.

Carvalho (2008) afirma que no Brasil a Educação ambiental aparece na legislação em 1973 como atributo da primeira secretaria especial do meio ambiente (Sema) ligada à presidência da República. Em decorrência das recomendações da conferencia de Estocolmo ${ }^{2}$ (1972) a secretaria foi criada. Para Carvalho (2008) este processo se apresenta como um marco inicial do debate

\footnotetext{
${ }^{2}$ No ano de 1972, foi realizada a importante Conferência de Estocolmo. Esse evento teve o fundamental objetivo de estabelecer estratégias, a fim de tentar reavivar a consciência da sociedade, para que a relação do homem com o meio ambiente ficasse mais equilibrada e justa. Assim, seria possível atender as necessidades dos povos mundiais no presente, sem que isso comprometesse a sobrevivência das gerações futuras e do planeta, como um todo.

Essa conferência, que foi realizada pela Organização das Nações Unidas - ONU - teve lugar na cidade de Estocolmo, capital da Suécia. A importância desse encontro é enorme, porque simboliza um primeiro esforço no sentido de tentar preservar o meio ambiente, em nível planetário.
} 
ambiental em nível internacional. Para a mesma autora, é com o avanço da consciência ambiental nas décadas de 80 e 90 que a Educação Ambiental se expande no Brasil, tornando-se objeto de políticas públicas e da agenda de movimentos sociais. No plano internacional, Carvalho diz que:

(...) Educação ambiental surge como recomendação para políticas públicas na I Conferência Internacional sobre Meio Ambiente em 1972, em Estocolmo, Suécia. Depois disso em 1977, a educação ambiental foi tema da I Conferência sobre Educação Ambiental em Tbilisi (ex URSS), e 20 anos depois da II conferência em Tessalônica, Grécia. Tais conferências foram promovidas pela Organização das Nações Unidas (ONU) dentro de um conjunto de outras temáticas voltadas para a questões sociais (gênero, população, cidades, etc). Entre as décadas de 1970 e 1990, num ciclo de 20 anos que se convencionou chamar o "ciclo social" da ONU. Essa mobilização internacional estimulou durante essas décadas, a adoção por parte de diversos países de políticas e programas mediante os quais a educação ambiental passou a integrar políticas nacionais (CARVALHO, 2008 p. 14)

Para a mesma autora, a Educação Ambiental, no Brasil, avança a partir dos anos 80, se consolidando de maneira significativa nos anos 90 a partir da Conferência da ONU para o Meio Ambiente e Desenvolvimento Sustentável (CNUMAD) em 1992. Durante a ECO-92 foi criada a Rede Brasileira de EA (REBEA), composta por ONGs, educadores e instituições diversas relacionadas à educação (CARVALHO, 2008).

Carvalho (2008) chama atenção para o fato de que a Educação Ambiental difere de outras pedagogias, sendo uma resposta da educação a preocupações da sociedade com a questão ambiental, o que torna fundamental compreender a Educação Ambiental dentro do contexto dos movimentos ecológicos. A autora afirma ainda que:

Os movimentos ecológicos contribuíram para levar a crítica ao capitalismo industrial à esfera pública e promover um ideário emancipatório que poderia ser considerado como fundador da história política do campo ambiental. (CARVALHO, 2008 p. 16)

É diante desse constructo que a década de 70 é considerada por Carvalho (2008) como marco do surgimento do movimento ecológico no Brasil, sendo a partir de 1974 que começam a surgir associações e movimentos ambientalistas no Sul-Sudeste, mesmo com o regime militar. 


\section{2. \\ Pressupostos teóricos da Educação Ambiental Crítica}

Neste capítulo, pretende-se desenvolver os pressupostos do que vem a ser uma Educação Ambiental crítica. Inicialmente cabe destacar que nosso esforço se concentra em tentar mapear na literatura perspectivas capazes de oferecer contribuições que rompam com as dicotomias homem versus Natureza (construída através da alienação capitalista) e que seja capaz de desenvolver nos indivíduos práticas que rompam com a lógica capitalista vigente, que estimula o consumismo desenfreado sem refletir as consequiências disso para o Meio Ambiente. Sendo assim, a Educação Ambiental é uma práxis que tem por finalidade a construção de valores, conceitos, habilidades e atitudes que possibilitem o entendimento da realidade de vida (Loureiro, 2002).

Loureiro (2003) afirma que existem dois eixos para a Educação como vetor de transformação, sendo um conservador, uma vez que promove apenas transformações superficiais para garantir o status quo, ou seja, para garantir a manutenção do modelo vigente de forma a-histórica. $\mathrm{O}$ autor nos alerta ainda que a Educação Ambiental por si só não é garantia de transformação, e cita como exemplo os programas de coleta de lixo que muitas escolas desenvolvem o que acaba por reproduzir uma Educação Ambiental voltada para a reciclagem, sem discutir o padrão de consumo.

O outro eixo de Educação Ambiental diz respeito a uma Educação Ambiental que, de acordo com Loureiro (2003), pode ser considerada revolucionária e emancipatória. Nas palavras do autor:

Há um outro eixo revolucionário e emancipatório que pode ser realmente chamado de educação transformadora, em que a dialética forma e conteúdo se realiza plenamente, de tal maneira que as alterações da atividade humana implicam em mudanças radicais individuais e coletivas, locais e globais, estruturais e conjunturais, econômicas e político-sociais, psicológicas e culturais; em que o sentido de revolucionar se concretiza como sendo a transformação integral do ser e das condições materiais e objetivas de existência (LOUREIRO, 2003 p. 3)

Loureiro (2003) nos adverte de que é preciso buscar compreender e adotar um corpo teórico que seja compatível com uma Educação Ambiental transformadora. Para o mesmo, poucas são as linhas teórica que fornecem subsídios tão consistentes quanto o pensamento marxista. Nessa perspectiva, educar para transformar é agir conscientemente processos sociais que possuem 
projetos distintos de sociedade, que se apropriam da Natureza de forma desigual (LOUREIRO, 2003).

Dessa forma uma Educação Ambiental transformadora deve estar implicada com a práxis educativa transformadora, o que exige dos educadores um ensino pautado na criticidade ${ }^{3}$. O que estamos chamando de práxis educativa transformadora, se relaciona à idéia de Mézáros (2008) de que o objetivo dos que lutam contra a sociedade mercantil, a alienação e a intolerância é a emancipação humana. Isso quer dizer que é necessário romper com a Educação que visa atender os interesses do capital. É preciso romper com os valores das classes dominantes construindo uma Educação que seja capaz de levar os educandos à superação das relações de opressão. Torna-se necessário e fundamental desconstruir a amálgama responsável por uma educação mercadológica voltada às satisfações do capitalismo. Nesse sentido, há ainda uma necessidade de ruptura com o conhecimento historicamente construído, pautado nas leis lógicas e atomísticas da ciência moderna. Nesse sentido Loureiro (2003) nos informa que:

Logo, uma Educação Ambiental Transformadora não é aquela que visa interpretar, informar e conhecer a realidade, mas busca compreender e teorizar na atividade humana, ampliar a consciência e revolucionar a totalidade que constituímos e pela qual somos constituídos. (LOUREIRO, 2003 p. 8)

Ou seja, torna-se-ia imprescindível abrir novos espaços para a construção de novos conhecimentos que se pautem nas atividades humanas. Até porque o modelo de ciência instrumentalizadora e excludente que conhecemos é responsável pelos problemas ambientais, e a mesma tem se mostrado incapaz de solucionar os mesmos. Além disso, o autor chama atenção que a educação ambiental numa perspectiva transformadora não busca reproduzir os valores dos grupos dominantes, mas sim promover processos e práticas reflexivos que levem a consolidação de valores que possam ser entendidos e aceitos como favoráveis à sustentabilidade global, à justiça social e à preservação da vida Loureiro (2003).

\subsection{1.}

\section{A dialética em Marx}

Para Loureiro (2010) a dialética em Marx é um método que, além de ser instrumento de entendimento, pesquisa e ação na realidade, é uma visão de

\footnotetext{
${ }^{3}$ Ver Freire (1996).
} 
Natureza, de mundo, de sociedade e de ser humano. Nesse método não há separação possível entre ser humano da Natureza. Na dialética marxiana toda existência é interdependente, organizada em padrões dinâmicos capazes de gerar distintas realidades na história. É um método que busca o concreto, o como produzimos a existência, como transformamos e somos transformados na Natureza (LOUREIRO, 2010).

De acordo com Loureiro, em A ideologia alemã (2002), Marx reconhece apenas uma ciência, a ciência da história. Com isso, Marx quis destacar a historicidade da existência da Natureza e a importância de um pensamento dialético situado no tempo-espaço. Loureiro destaca ainda que a disciplinarização da ciência e as reflexões fatorialistas, intrínsecas à atual divisão social do trabalho, levam a visões fragmentadas e reproduzem a alienação no capitalismo. Loureiro afirma que para o filósofo da práxis:

Nenhuma categoria é fixa e imutável, mas se dá na história, constituindo-se em elementos de explicação das transformações. Como é um método historicizado, na dialética os conceitos não são utilizados abstratamente na explicação dos atos e fenômenos sociais. (LOUREIRO, 2010 p.72)

Loureiro nos adverte que no caso do Homo sapiens, a dialética marxiana evita que a relação entre organismo e ambiente seja concebida por causação direta. Segundo o autor, isso significa que precisamos entender o singular de cada espécie para não cairmos em dualismos que separam o homem da Natureza.

Citando Semeraro (2005), Loureiro (2010) destaca que as relações de nossa espécie na Natureza são pensadas com base nos conceitos de trabalho e práxis. Dessa forma, as relações sociais não formam um todo natural e nem se esgota no biológico. Loureiro vai afirmar ainda que a totalidade não é um todo fechado, mas trata-se da compreensão ampla e contraditória da realidade, vista como histórica e superável.

O autor nos informa que nossa atividade não se restringe aos processos cognitivos, estendendo-se às esferas da emoção e das necessidades e vontades, constantemente recriadas pela dinâmica existencial. Segundo Loureiro (2010) isso nos ajuda a entender que o problema do consumo não se elimina na escolha de mercadorias e na redução individual de consumo. Primeiramente porque poucos escolhem livremente, segundo porque é ingênuo pensar o consumo fora do ciclo econômico. 
Outro exemplo citado por Loureiro e que interessa aos educadores ambientais diz respeito à reciclagem de materiais. Para o autor não se pode desconsiderar o modo de produção ao tratar da reciclagem. Ou seja, não é porque reciclamos que podemos consumir sem limites. Loureiro destaca que:

A reciclagem tem que ser pensada como qualquer outra categoria, como relação. Ou seja, para ser efetiva segundo os interesses ambientalistas democráticos, é preciso ser problematizada, articulada com aquilo que a define (estilos de vida, padrão de consumo e de produção, quem se apropria dos benefícios da reciclagem etc.) e realizada para a transformação das relações e, portanto da realidade. (LOUREIRO, 2010 p.75)

Segundo Loureiro, Marx foi um dos pioneiros na denúncia da espoliação da Natureza, e o fez por meio de conceitos como: alienação, expropriação e dominação, além da análise da forma como se dão as relações sociais no capitalismo e os caminhos para a sua superação. Para ilustrar o pensamento de Marx apresento a citação abaixo:

A burguesia, durante o seu domínio de quase cem anos, criou forças produtivas mais maciças e colossais do que todas as gerações precedentes juntas. Sujeição das forças da natureza pelo homem, maquinarias, aplicação da química na indústria e na agricultura, navegação a vapor, estradas de ferro, telégrafos, remoção do cultivo de continentes inteiros, canalização de rios, populações inteiras conjuradas fora de suas áreas - que século anterior teve, mesmo que fosse um pressentimento de que tais forças ficariam inativas no colo do labor social? (MARX \& ANGELS, 1998 p.17)

A citação acima mostra de forma bastante clara a maneira como Marx no século XIX identificou as relações entre a burguesia com a Natureza. Essa denúncia se refere, sobretudo à violência insolente da burguesia em obter êxito na acumulação de capital. Infelizmente a lucidez de Marx no século XIX se apresenta de forma tão atual que nos permite perceber que o que mudou hoje é que o discurso da classe dominante se traveste de um cinismo desonesto e ainda tira proveito da crise ambiental. Tudo isso em nome do "progresso" ou ainda do que alguns apregoam de "desenvolvimento sustentável", ainda que com suas contradições inerentes a esse "avanço", corroborando ainda mais com o discurso proferido por Marx no século XIX.

Loureiro nos adverte que é preciso separar Marx dos marxismos das incontáveis escolas criadas a partir dele, que se vinculam a ele, mas que evidentemente não são idênticas a ele. 


\section{3. Epistemologia ambiental}

Neste sub-capítulo pretende-se delinear os principais conceitos e discussões acerca da questão ambiental. Inicialmente será feita uma discussão a partir das proposições de Leff. Este autor parte de uma crítica ao modelo de ciência cartesiana, do pensamento único e da falta de diálogo efetivo entre os diferentes campos do conhecimento para a construção de um saber ambiental. Sendo assim, chama atenção para a necessidade de um projeto transdiciplinar onde haja a construção de um novo paradigma científico que trate da questão ambiental, destacando a necessidade de um pensamento complexo. Em seu escopo teórico, o autor recebe uma influencia do marxismo ao reconhecer que o problema ambiental requer uma análise profunda das crises do capital, mas reconhece também a necessidade de uma articulação teórica com outras ciências para dar conta do problema ambiental. Nesse sentido, utiliza autores da escola de Frankfurt e o pensamento complexo de Morin em busca de uma epistemologia ambiental, uma vez que as análises dos processos socioambientais necessitam de um projeto teórico.

Em seu livro intitulado Epistemologia Ambiental, Leff (2010) nos adverte que as relações entre o conhecimento teórico e os saberes práticos aceleraram-se com o advento do capitalismo, com o surgimento da ciência moderna e com a institucionalização da racionalidade econômica. É com o modo de produção capitalista que se produz a articulação entre conhecimento científico e a produção de mercadorias. Para o autor a necessidade de elevar a mais-valia traduz-se numa necessidade de incrementar sua eficiência produtiva o que gera a substituição da mecanização pela cientifização dos processos produtivos. Ainda assim, Leff nos informa que a ciência moderna não é resultado da transformação da natureza em objetos de trabalho, mas sim o resultado de transformações ideológicas vinculadas à dissolução do sistema feudal e do surgimento do capitalismo, que estabeleceram um novo campo epistemológico para a produção de conhecimento. Campo esse que inaugura uma forma de fazer ciência onde o homem se coloca no centro do conhecimento do mundo, dando início a uma racionalidade que irá comprometer o Meio Ambiente.

Para Leff (2010), o saber sobre a realidade é o resultado de práticas sociais distintas. $\mathrm{O}$ autor afirma que as ciências não apreendem diretamente as coisas 
empíricas, mas estabelecem paradigmas teóricos que permitem dar conta das relações fundamentais entre os processos que constituem seus diferentes objetos do conhecimento. Afirma ainda que "o pensamento conceitual estabelece as relações fundamentais do real, enquanto que o conhecimento técnico permite a apropriação produtiva ou ideológica da realidade.” (LEFF, 2010 p.27).

Leff (2010) destaca que desde a antiguidade se busca conhecer a essência das coisas, mas o conhecimento do real é uma emergência epistêmica relativamente recente. A partir de Marx, o autor afirma que o concreto material só pode ser apreendido no conhecimento pela produção teórica dos conceitos que integram a síntese de múltiplas determinações e constituem, ao mesmo tempo, o princípio do processo real. Destaca ainda que:

Esta epistemologia materialista não se confunde com o pragmatismo epistêmico atribuído a Marx, no qual o conhecimento se reduziria ao saber sobre as coisas enquanto objetos de trabalho, nem à concepção da produção teórica como o simples reflexo do real no pensamento (LEFF, 2010 p. 28)

É através da constituição de seus objetos teóricos que podemos apreender os processos reais. $\mathrm{O}$ autor afirma que o conceito de um objeto empírico não é objeto de nenhuma ciência. Nesse sentido, podemos notar uma crítica a forma de produção da ciência moderna onde o autor afirma que os objetos das ciências são trans-individuais, trans-objetais. O autor destaca ainda que:

É então necessário diferenciar a articulação técnica de diferentes ramos do conhecimento para a resolução de problemas práticos do capital e seus efeitos no real histórico objeto do materialismo histórico, com sua articulação teórica com outras ciências para explicar o processo atual do capitalismo frente aos desafios da globalização e da sustentabilidade ecológicas (LEFF, 2010 p. 31)

Sobre a articulação teórica - articulação técnica, o autor nos informa que:

A partir da perspectiva histórica da acumulação capitalista, a diversificação e o avanço do conhecimento não aparece como um simples efeito da divisão "natural" do trabalho ou como uma evolução interna das ciências. Avançada a fase da acumulação extensiva, fundada na exploração da mais-valia absoluta, a elevação da taxa de lucro exigiu um aumento na eficiência produtiva dos processos de trabalho (LEFF, 2010 p. 32)

O que o autor quer nos dizer é que a acumulação do capital transformou os conhecimentos sobre a natureza em forças produtivas, mas, ainda assim, esses efeitos não se transformaram em critérios de cientificidade do conhecimento nem em condições de possibilidade de suas articulações teóricas. Sendo assim, o que o autor nos propõe é a existência de uma articulação interna dos conceitos e categorias de uma ciência como pontos cruciais da estrutura de uma teoria em 
torno a seu objeto de conhecimento, articulados a conceitos de outras ciências. Como exemplo o autor nos diz que a infraestrutura econômica articula-se com a superestrutura ideológica, as relações sociais de produção enlaçam as práticas produtivas, jurídicas, políticas e ideológicas a partir da luta de classes (LEFF, 2010 p.34).

Nesse sentido, a epistemologia materialista está fundada na articulação dos conceitos de uma teoria pensada do real que produz um efeito de conhecimento de uma realidade complexa e não apenas da soma das partes, sendo para Leff a produção conceitual que permite explicar os efeitos do modo de produção capitalista sobre suas formações ideológicas e culturais, e sobre suas bases ecológicas de sustentabilidade.

\subsection{1. A questão ambiental}

Leff (2010) afirma que a crise ambiental surgiu nas últimas décadas do século XX como uma crise de civilização, colocando em cheque a racionalidade econômica e tecnológica dominantes. Esta crise, segundo o autor, pode ser explicada a partir de diferentes perspectivas. De um lado estão os que acreditam que a crise seja uma expressão pelo crescimento populacional, e de outro estão os que percebem a crise como efeito da acumulação do capital, que ao desejar a maximização dos lucros, acaba por explorar os recursos naturais. Diante da crise ecológica, somos levados buscar novas estratégias conceituais e epistemológicas que orientam a construção de uma racionalidade produtiva que permita existência de um mundo sustentável.

Leff (2010) destaca que uma das principais causas da problemática ambiental foi atribuída ao processo histórico do qual emerge a ciência moderna e a Revolução Industrial, o que acaba por promover uma compartimentalização da realidade em campos específicos do conhecimento, e que produz ainda uma busca por novos métodos capaz de articular esses conhecimentos. No que se refere ao saber ambiental, essa postura atomística da ciência nos leva a buscar um projeto totalizante. Leff afirma também que o conhecimento ambiental não pode ser compreendido sem a integração de campos muito diversos do saber. Para o autor as estratégias políticas orientadas à solução do problema ambiental requer uma 
análise profunda das crises do capital e de suas próprias estratégias de sobrevivência.

Dessa forma, transformar a racionalidade ambiental exige um trabalho teórico e a elaboração de estratégias que apóiem práticas capazes de construir uma racionalidade para alcançar os propósitos do desenvolvimento sustentável igualitário. (LEFF, 2010).

Cabe ainda advertir que essas estratégias conceituais não podem advir do modelo econômico dominante.

A problemática ambiental, segundo Leff, não é neutra nem alheia aos interesses econômicos e sociais, tendo sua gênese no modo de produção capitalista, na racionalidade econômica, o que resulta em efeitos econômicos, sociais e ecológico desiguais. Afirma ainda que as soluções conservacionistas do norte são insuficientes para dar conta da problemática ambiental dos países do sul, o que podemos apreender como uma necessidade de complexificar as análises das relações sociedade-natureza.

Sobre a complexidade da análise da questão ambiental, o que o autor propõe é que se saia das verdades científicas inscritas em formações ideológicas. Estabelece desse modo uma estratégia conceitual que combata os principais efeitos ideológicos do reducionismo ecologista. Sobre os efeitos ideológicos do reducionismo ecologista e do funcionalismo sistêmico o autor infere que as teorias socioambientais desconhecem a especificidade das relações de produção. Além disso, o autor nos informa que metodologizar a ecologia de forma a transformá-la numa ciência das ciências impede a reconstrução do real histórico a partir da especificidade e articulação de processos de ordem natural e social. É necessário romper com a uniformização da natureza do real. Critica a orientação da produção de conhecimentos por meio do critério científico na eficiência da articulação entre ciência, técnica e sistema social. Essa postura deixa de lado o potencial criativo e propositivo do conhecimento.

Afirma também que os processos ecológicos não podem ser entendidos como o estudo das determinações estruturais e dos sistemas de organização de diferentes ordens do real. Essa redução do entendimento dos processos ecológicos, não se constitui como princípio último do conhecimento dos processos ecológicos. Nesse sentido, o autor busca a produção de um saber holístico e sistêmico e um todo social sem divisões. Leff (2010) diz também que 
para poder implementar políticas ambientais eficazes é necessário reconhecer os efeitos dos processos econômicos atuais sobre a dinâmica dos ecossistemas.

\subsection{2.}

\section{Ambiente e objeto científico transdiciplinar}

De acordo com o autor o propósito de integrar diferentes áreas do conhecimento é anterior à problemática ambiental. A mesma origina-se no processo de aprofundamento das relações capitalistas que em nome da produtividade do capital. Entretanto, nos adverte o autor, estes campos de integração de conhecimentos não constituem objetos científicos interdisciplinares. Sobre o conhecimento ambiental, é necessária uma articulação de diferentes áreas do conhecimento de modo a apreender a realidade de maneira holística. De acordo com Leff (2010 p.84), a transdiciplinaridade pode ser definida como:

(...) um processo de intercâmbio entre diversos campos e ramos do conhecimento científico, nos quais uns transferem métodos, conceitos, termos e inclusive corpos teóricos inteiros para outros, que são incorporados e assimilados pela disciplina importadora, induzindo um processo contraditório de avanço/ retrocesso do conhecimento, característico do desenvolvimento das ciências.

$\mathrm{O}$ autor nos alerta sobre possíveis efeitos negativos do processo transdiciplinar como o desconhecimento dos objetos específicos das ciências e de seus campos de conhecimento. Entretanto, podemos inferir a partir de um olhar positivo que o processo transdiciplinar contribui para o avanço do conhecimento, uma vez que os conceitos e categorias são retrabalhados e ressignificados até adquirir um sentido próprio no corpo teórico. O autor cita como exemplo o enriquecimento do pensamento marxista sobre as causas da crise ecológica.

\subsection{3.}

Racionalidade ambiental

Para Leff (2010) a problemática ambiental propõe a necessidade de articulação de um conjunto de disciplinas, tanto das ciências naturais, quanto sociais para que se possa apreender a multicausalidade dos processos de ordem natural e social que determinam a questão ambiental. Nesse sentido o autor propõe pensar a questão ambiental a partir de uma perspectiva complexa inserida numa interdisciplinaridade. Dessa forma, sugere um diálogo - resultado de uma necessidade- de articular a relação entre o saber sociológico e a problemática 
ambiental. Para Leff, há três teorias que aparecem como campos férteis para compreender a racionalidade ambiental, sendo eles: o conceito de formação socioeconômica em Marx, o conceito de racionalidade em Weber e o conceito de saber em Foucault. É a partir desses três conceitos que o autor desenvolve as categorias de formação socioambiental, de racionalidade ambiental e de saber ambiental.

Como já foi dito anteriormente, diante da questão ambiental, estamos diante da necessidade de um pensamento holístico e sistêmico. Leff (2010) vai dizer que enquanto os problemas atuais buscam um pensamento complexo, o pensamento científico e filosófico tem estado marcado por uma tendência pela busca e síntese mais do que pela análise e articulação destes processos. Afirma ainda que dentro da perspectiva do pensamento positivista, o materialismo histórico e dialético ao contrário, abriu um campo para o estudo dos processos econômicos e sociais de forma mais abrangente, além de abrir espaço para perceber as conexões entre

sociedade e Natureza. É por meio do materialismo histórico e dialético que se observa o conhecimento da estrutura produtiva que determina a racionalidade econômica.

\subsection{4. O conceito de racionalidade ambiental}

Para Leff (2008), o processo civilizatório da modernidade fundou-se na racionalidade econômica e instrumental. Nesse sentido, a problemática ambiental questiona os custos socioambientais derivada de uma racionalidade produtiva. Sendo assim, a questão ambiental impõe a necessidade de introduzir reformas para contornar os problemas ambientais.

Para Leff (2008) a racionalidade ambiental resulta de um conjunto de práticas sociais que requer a formação de uma consciência ecológica; o planejamento transetorial da administração pública e a participação da sociedade na gestão dos recursos ambientais, além da interdisciplinarização do saber.

Leff (2008) acredita que toda racionalidade social deve articular um sistema de teorias, conceitos, normas jurídicas e instrumentos técnicos. Em suas palavras:

A categoria de racionalidade ambiental integra os princípios éticos, as bases materiais, os instrumentos técnicos e jurídicos e as ações orientadas para a gestão democrática e sustentável do desenvolvimento; por sua vez, converte-se num conceito normativo para analisar a consistência dos princípios do ambientalismo 
em suas formações teóricas e ideológicas, das transformações institucionais e programas governamentais, assim como dos movimentos sociais, para alcançar estes fins. (LEFF, 2008 p.135)

A racionalidade ambiental se constitui então numa constante inter-relação entre teoria e práxis. Leff (2008) destaca ainda que a construção de uma racionalidade ambiental depende da constituição de novos atores sociais e se constrói mediante a articulação de quatro esferas de racionalidade, que são: uma racionalidade substantiva, uma racionalidade teórica, uma racionalidade instrumental e uma racionalidade cultural.

Para Leff (2008) a racionalidade substantiva se constitui como um sistema axiológico, ou seja, os valores predominantes numa sociedade para a orientação de valores que sejam capazes de construir uma racionalidade ambiental. A racionalidade teórica é aquela que vai orientar os valores da racionalidade substantiva para a construção de uma nova racionalidade social e produtiva. $\mathrm{Ou}$ seja, a partir dos processos ecológicos, culturais, tecnológicos, políticos e econômicos é que a racionalidade ambiental será construída, a partir da articulação entre racionalidade substantiva e teórica. A racionalidade instrumental se apresenta enquanto criadora dos vínculos técnicos, funcionais e operacionais. É essa racionalidade a responsável pela prática de uma racionalidade ambiental. Já a racionalidade cultural seria uma espécie de cultura não homogênea onde os sujeitos produziriam suas identidades de forma coerente com suas práticas sociais e produtivas tendo em vista as potencialidades de seu entorno geográfico e de seus recursos naturais.

\subsection{5.}

\section{Saber ambiental}

Leff (2010) vai dizer que a globalização da degradação ambiental impôs a uma série de disciplinas pensar a problemática ambiental de forma complexa. Afirma ainda que surgiram novos enfoques metodológicos para apreender o que o mesmo chama de multicausalidade. Para o autor o ambiente não é uma categoria biológica, mas sim sociológica que diz respeito a uma racionalidade configurada por comportamentos, valores e saberes, bem como por novos potenciais produtivos. Entretanto, o saber ambiental é um saber que ainda se encontra marginalizado do logos científico. Sendo assim, a proposta do autor é de provocar 
um confronto de racionalidades e tradições com um diálogo aberto à outridade, à diferença e à alteridade.

Para o autor, a problemática ambiental demanda a produção de um corpo complexo e integrado de conhecimentos sobre os processos sociais e ambientais, sendo necessário para isso a transformação dos paradigmas científicos tradicionais. Mas, nos adverte que:

A inter e transdiciplinaridade que demanda o saber ambiental não é a busca de um paradigma globalizante do conhecimento, a organização sistêmica do saber, e a uniformização conceitual por meio de uma metalinguagem interdisciplinar. (LEFF, 2010 p. 163)

Sendo assim, o que o autor quer chamar atenção é de que não basta a internalização do conhecimento ambiental no corpo das diferentes disciplinas e áreas do conhecimento. Sendo necessária a inserção do conhecimento ambiental dentro dos paradigmas das ciências, o que obviamente perpassa por uma relação de poder.

Nesse sentido a interdisciplinaridade implica na integração de processos naturais e sociais o que implica na formulação de novas estratégias conceituais para a construção de um novo paradigma produtivo e novas relações de poder, de forma a superar a racionalidade econômica e instrumental que legitimaram a visão hegemônica existente. Leff (2010) destaca que a emergência do saber ambiental rompe com o círculo "perfeito" das ciências, a crença numa idéia única e absoluta, abrindo-se para a dispersão do saber.

\section{4 .}

\section{O conceito de natureza}

Para Gonçalves (2013) toda sociedade, toda cultura cria, inventa, institui uma determinada idéia do que seja Natureza. Nesse sentido, o conceito de Natureza não é natural. Dessa forma, o conceito de Natureza é criado e instituído pelos homens. Sendo assim, o autor faz uma reflexão de como foi e é concebida a Natureza na nossa sociedade.

Gonçalves (2013) nos mostra que sem que percebamos, usamos em nosso dia a dia uma série de expressões que trazem em seu bojo a concepção de Natureza. Ele cita como exemplo o fato de chamarmos de burro o aluno ou pessoa que não entende o que se fala ou ensina; de cachorro o mau caráter, de cavalo o mal educado; de vaca piranha e veado aquele que não fez a opção sexual 
considerada correta, dentre outros exemplos. Nesse sentido, o que o autor quer nos mostrar é que em todos os casos, são utilizados nomes de animais (Natureza) de forma negativa que se opõe a comportamentos considerados cultos, civilizados e bons. Citando Lévi-Strauss, Gonçalves nos mostra que os romanos chamavam de bárbaros os povos tidos como não civilizados, sendo que a palavra bárbaro significava o canto desarticulado das aves, sendo assim, bárbaros eram aqueles considerados selvagens que quer dizer selva, sendo o oposto da cultura.

Dessa forma, para Gonçalves, a Natureza em nossa sociedade se define por aquilo que se opõe à cultura. A cultura é tomada como algo superior e que conseguiu controlar e dominar a natureza.

De acordo com o autor, podemos dizer que a separação homem-Natureza é uma característica marcante do pensamento que tem dominado o mundo ocidental, onde a matriz filosófica se encontra na Grécia e Roma clássicas. O autor esclarece ainda que esse pensamento se consolida não por ser superior a outros, mas sim por uma imposição. No Ocidente, já houve época em que o modo de pensar a Natureza foi radicalmente diferente do que tem dominado nas épocas moderna e contemporânea, muito embora, de acordo com Gonçalves (2013) possamos encontrar na Idade Média e entre filósofos do período clássico grego essa mesma visão dicotomizada de homem e Natureza. Entretanto, é com a influência judaico-cristã que a oposição homem-natureza e espírito matéria adquiriu maior dimensão. Sobre isso, Gonçalves (2013) nos diz que:

Os cristãos vão afirmar decididamente que "Deus criou o homem à sua imagem e semelhança". Note bem: o homem foi criado à imagem e semelhança de Deus (Deus aparece com letra maiúscula e não como para os pré-socráticos). O homem é assim dotado de um privilégio. (GONÇALVES, 2013 p. 32)

Para o mesmo autor dois aspectos da filosofia cartesiana vão marcar a modernidade: 1) o caráter pragmático que o conhecimento adquire. Sendo assim, afirma Gonçalves, o conhecimento cartesiano vê a Natureza como um recurso. 2) o antropocentrismo, ou seja, o homem passa a ser visto como o centro do mundo. Nesse sentido o homem passa a ser possuidor e senhor da Natureza, a partir da instrumentalização do método científico.

O antropocentrismo consagrará a capacidade humana de dominar a Natureza. Para o autor, a Natureza dessacralizada não mais povoada por deuses, torna-se objeto. Gonçalves vai nos mostrar ainda que com o capitalismo essa tendência será levada às últimas conseqüências. Nos mostra ainda que o século 
XIX será o triunfo desse mundo pragmático, com a ciência e a técnica adquirindo como nunca antes, um significado central na vida dos homens. Nesse sentido o autor destaca que:

A natureza, cada vez mais um objeto a ser possuído e dominado, é agora dividida em física, química, biologia. O homem em economia, sociologia, antropologia, história, psicologia, etc. Qualquer tentativa de pensar o homem e a natureza de uma forma orgânica e integrada torna-se agora mais difícil, até porque a divisão não se dá somente enquanto pensamento. (GONÇALVES, 2013 p. 34)

Para o autor, a ideia de uma Natureza objetiva e exterior ao homem, cristaliza-se com a civilização industrial inaugurada pelo capitalismo. Sendo assim, as ciências da Natureza se separam das ciências do homem, o que cria um abismo entre uma e outra. "A ecologia enquanto saber, e, sobretudo, o movimento ecológico tentam denunciar as conseqüências dessas concepções, embora o façam, muitas vezes, permeados pelos princípios e valores dos seus detratores". (GONÇALVES, 2013 p. 35)

\subsection{1. \\ A ciência diante da Natureza}

Neste sub-capítulo, pretende-se discutir a concepção de Natureza diante da ciência. Gonçalves (2013) insiste que toda sociedade, toda cultura, cria um determinado conceito de Natureza, ao mesmo tempo em que cria e institui suas relações sociais. Nesse sentido, o autor acredita que no interior destas relações sociais está imbutida uma determinada concepção de Natureza. Da mesma forma, a ciência moderna também é instituída por uma sociedade, por uma cultura. No que diz respeito à ciência moderna, Gonçalves (2013) vai caracterizá-la em torno de três eixos:

1) A oposição homem e natureza.

2) A oposição sujeito e objeto.

3) O paradigma atomístico-individualista.

\subsection{2.}

\section{A oposição homem versus Natureza}

Aqui o autor vai nos mostrar como as ciências estão divididas. De um lado, temos as ciências da Natureza e, de outro, as ciências humanas. As ciências da Natureza, segundo o autor, vivem radicalmente separadas das ciências humanas. 
Como exemplo, o autor cita a Geografia, ciência onde teoricamente não caberia tanta divisão, ainda assim mantém a dicotomia Geografia Física versus Geografia Humana. Gonçalves destaca ainda que a ecologia tem promovido uma conversa entre esse espaço teórico e político que os geógrafos não têm conseguido dar conta.

Para esse autor, a busca de algo que comprove que o homem não é Natureza se constitui numa verdadeira obsessão do pensamento herdado no Ocidente. $\mathrm{O}$ homem é um ser social, é o que nos dizem. Para demonstrar tal afirmação, Gonçalves nos mostra que são usados exemplos de crianças que foram encontradas completamente isoladas de uma sociedade e cultura. As dificuldades encontradas com a linguagem, por exemplo, são citados como exemplo para corroborar a idéia de que o homem só é homem se vivendo socialmente. Entretanto, o desenvolvimento da etologia, ciência que estuda o comportamento dos animais na sua vida em grupo indica que viver em sociedade é uma característica do reino dos seres vivos, sobretudo dos animais. Mais adiante, será mostrado a partir das proposições de Gonçalves (2013) que tal problema em suma só se coloca em virtude do pressuposto atomístico-individualista que tem dominado o pensamento ocidental e, por conseqüência, a ciência moderna.

Dessa forma, o que o autor quer nos mostrar é que dizer que o homem é um ser social como se isso os distinguisse dos demais seres da Natureza, pouco faz avançar em qualquer tentativa ou esforço de diferenciação entre homem e Natureza, na medida em que os seres vivos, sobretudo os animais, já vivem socialmente. $\mathrm{O}$ autor chama atenção dizendo que isso não significa que o homem não seja um animal social, mas sim que o homem é social porque é animal e os animais vivem socialmente. Ao mesmo tempo, devemos tomar cuidado e não reduzir o homem ao reino animal sem maiores reflexões. Sendo assim, da mesma forma que entre os animais há diferenças, o homem também possui suas especificidades.

Gonçalves (2013) afirma que autores como Lévy-Strauss vão tentar distinguir o homem da Natureza pelo fato de os homens estabelecerem interdições ou proibições para o acasalamento. Sendo assim, o relacionamento sexual entre humanos se estabelece a partir de regras arbitrárias, artificiais, culturais onde algumas possibilidades não são possíveis. Por exemplo, irmãos consaguíneos, pai e filha, mãe e filho não podem casar entre si. Dessa forma cada cultura teria suas 
próprias interdições, seus próprios tabus, e nisso os homens se distinguiriam dos animais, da Natureza, onde não há regras e impera a promiscuidade, ou ausência de leis e normas regulando os acasalamentos.

\subsection{3.}

\section{A oposição sujeito versus objeto}

De acordo com Gonçalves (2013) no mundo moderno, o método ganha destaque com Descartes. O homem, dispondo do domínio do método poderá ter acesso aos mistérios da Natureza e assim ser senhor possuidor da mesma. $\mathrm{O}$ autor afirma que para os gregos, a palavra método significava caminho a ser seguido. Nesse sentido, a ciência tenta conhecer o que é desconhecido. Citando Bachelard, o autor afirma que nenhum método pode ser construído a não ser na relação com o objeto. Gonçalves (2013) vai dizer ainda que sujeito e objeto pressupõem uma relação, um diálogo permanente, pois é nessa tensão que se produz o conhecimento. Para o autor, a separação entre espírito e matéria, assume feições modernas na separação entre sujeito e objeto. Nesse sentido, o homem debruça-se sobre a Natureza (objeto), coisificando-a. De acordo com Gonçalves (2013 p.43):

A Revolução industrial, muito mais que uma profunda revolução técnica, foi o coroamento de um processo civilizatório que almejava dominar a natureza e para tanto submeteu e sufocou os que a ele se opunham. O absurdo é que tal projeto teve- de antemão- de colocar o homem como não natureza, pois se o homem não fosse assim pensado a questão da dominação da natureza sequer se colocaria. Ironicamente, a falácia dessas teses que opõem peremptoriamente o homem à natureza fica evidenciada na constatação de que historicamente a dominação da natureza tem sido, via de regra, a história da dominação do homem pelo homem e isso, evidentemente, não tem nenhuma justificativa na natureza.

Dessa forma, pensar a Natureza, de acordo com o autor, significa trazer à tona profundas implicações filosóficas e aqueles que assumem plenamente a Ecologia devem ir o mais fundo possível nessas discussões a fim de evitar análises simplificadas.

É em nome da ciência, do seu rigor teórico e metodológico, que tem se justificado toda a prática de dominação dos homens e da Natureza.

Mais uma vez o autor enfatiza que a visão de mundo que tem sido hegemônica em nossa sociedade, com seus conceitos de Natureza e de homem, não se formou porque era melhor ou superior. Aceitar essa tese, segundo Gonçalves (2013 p.44), "só teria sentido se ignorássemos que muitas das questões 
que hoje levantamos já o haviam sido no passado por outros que foram sufocados, silenciados e oprimidos".

Gonçalves (2013) destaca ainda que a ciência, ela própria, também é instituída e, dessa forma como expressão de uma relação social não pode ser encarada como estando acima ou abaixo dos homens que a instituíram.

\subsection{4.}

\section{O paradigma atomístico-individualista da ciência moderna}

Gonçalves (2013) vai nos dizer que outra característica que tem marcado a ciência moderna, e com ela a abordagem do que seja Natureza e homem, é a concepção atomístico-individualista nela predominante. Na física, o átomo; na biologia, o organismo, depois a célula e, finalmente, a unidade elementar, a molécula; nas ciências do homem, o indivíduo - enfim, por toda parte a unidade elementar, indivisível, nuclear, o indivíduo, reinava. (GONÇALVES, 2013)

De acordo com o autor, na Economia, onde se utilizou os recursos teóricos e metodológicos das ciências da Natureza, o paradigma continua sendo o indivíduo. Essa concepção atomístico-individualista se apresenta como um verdadeiro retrocesso à Economia. De acordo com Gonçalves (2013), verificou-se na Economia autores como Quensnay, Adam Smith, David Ricardo, Karl Marx e Stuart Mill que embora tenham suas diferenças, sempre pensaram o processo econômico como constituído por- e constituindo - relações e classes sociais.

Para corroborar a idéia anterior, o autor mostra que se não houver, por exemplo, uma parte da sociedade totalmente desprovida de meios próprios para produzir a sua vida, o trabalho assalariado deixa de existir, e sem ele o capital não tem sentido. Dessa forma, o capital é uma relação social que se instaura num contexto de luta e não porque é melhor ou mais racional ou natural. Para Gonçalves (2013), estamos muito longe de uma concepção atomísticoindividualista. Dessa forma, o que o autor quer nos mostrar é que a reprodução, ou seja, a continuidade de uma sociedade em bases capitalistas pressupõem não só a garantia dos meios materiais de produção, mas também a reprodução das classes sociais, fazendo com que haja sempre pessoas sem condições de produzirem e se manterem para que se submetam aos donos do capital. Por último, o autor vai dizer que a sociedade humana não é a soma de indivíduos. Dessa forma, cai por 
terra o paradigma atomístico-individualista, e com ele, toda a visão que opõem Natureza e cultura.

\subsection{5.}

\section{A harmonia natural}

Anteriormente mostramos a partir das proposições de Gonçalves que muitas vezes utilizamos conceitos da Natureza para nos referirmos àquilo que é oposto à cultura e/ou civilização. Entretanto o autor vai nos mostrar que muitas vezes, utilizamos nomes de animais para nos referirmos àquilo que gostamos ou apreciamos. Quando chamamos alguém de gatinho, por exemplo, estamos querendo dizer que a pessoa é amável ou bela. Nesse sentido, a concepção de Natureza que está sendo utilizada se apresenta de forma romântica. Gonçalves (2013) vai dizer que no chamado mundo Ocidental, vivemos de fato essas duas vertentes: ou vemos a natureza como algo hostil, lugar da luta de todos contra todos, da chamada lei da selva, ou vemos a natureza como harmonia e bondade. Se a Natureza é o lugar de todos contra todos, nada mais necessário do que o Estado para impor a lei e a ordem.

Já os que percebem a Natureza como bondade e harmonia, encontram-se infelizmente, muitos que contraditoriamente partilham da idéia de que a Natureza é bondosa e que os homens é que a destroem. De acordo com o autor, a primeira vertente afirma o antropocentrismo e a segunda o naturalismo. Em ambas as concepções o conceito de Natureza se apresenta de forma descolada do homem, como sendo algo que é exterior ao homem. Para o autor, a dificuldade está em romper com um dos pressupostos da filosofia positivista que busca encontrar na Natureza o paradigma ou modelo para a sociedade humana e acrescenta que:

Não existem palavras naturais para falar de natureza. As palavras são criadas e instituídas em contextos sociais específicos e também por este modo o conceito de natureza não é natural. É por isso que tem sentido - e poder-se-ia dizer de maneira mais contundente que é necessário compreender bem o conceito de natureza que nossa sociedade instituiu. (GONÇALVES, 2013 p.63)

\subsection{6.}

\section{O conceito de Ecossistema}

Gonçalves (2013) vai nos mostrar que as descobertas científicas deste século, principalmente as da Biologia, conseguiram apontar para um conceito mais sólido que é o de Ecossistema. Esse conceito se apresenta de forma menos 
ambígua e menos vago do que os conceitos de Natureza e Meio Ambiente. Sendo assim, o conceito de Ecossistema tem servido para superar a concepção atomístico-individualista ao considerar o todo.

Para o autor, o Ecossistema compreende, antes de mais nada, o biótipomeio geofísico - e a biocenose - conjunto das interações entre os seres vivos de todas as espécies que povoam este biótipo. Constitui, assim, uma unidade complexa de caráter organizador ou sistema.

Gonçalves (2013) destaca que na verdade, cada ecossistema é um todo que se organiza a partir das interações dos seres que o constituem. Assim, o todo, e o Ecossistema, só existe pelas interações entre as partes e são essas complexas interações que o constituem.

\subsection{7. \\ O homem na Natureza e a natureza do homem}

Para Gonçalves (2013) um dos problemas da Ecologia e do pensamento ecológico tem sido a questão do tratamento dado ao homem. Essa dificuldade tem profundas raízes no nosso processo civilizatório. $O$ autor destaca que frequentemente ouvimos frases do tipo: "o homem está destruindo a Natureza". Entretanto os índios também são homens, porém manifestam outras formas de relação com a Natureza. Nesse caso, o que o autor nos coloca é que determinados tipos de organizações sociais estão destruindo a Natureza. Dessa forma, ao invocarmos o indígena como modelo estamos remetendo para uma idéia de um passado idealizado, de um paraíso perdido. O que Gonçalves vai mostrar, é que toda cultura é uma criação dos homens e se a nossa sociedade instituiu a forma presente de relação com a Natureza, é necessário que percebamos que esse conceito de Natureza não é natural e devemos por isso superá-lo.

Gonçalves afirma que a Biologia ao se afirmar enquanto ciência tem encontrado dificuldade para tratar do homem na sua especificidade e na sua complexidade. Para o autor, as dificuldades da Biologia são bem parecidas com as dificuldades da Geografia. Isso porque a Geografia ao se colocar enquanto ciência não ficou nem nas ciências humanas nem entre as ciências da Natureza. Tal fato pode ser constatado ao observarmos a produção geográfica mundial. Nesse sentido, o autor destaca que: 
Tanto a Biologia, a Ecologia como a Geografia têm tratado o homem exclusivamente como espécie biológica, não levando em consideração a especificidade e a complexidade desse animal-homem e, inclusive, passando por cima do fato, importantíssimo, de que o homem por natureza produz cultura. (GONÇALVES, 2013 p. 76)

No próximo capítulo será desenvolvida a análise dos artigos. Cabe destacar que os conceitos desenvolvidos no presente capítulo foram fundamentais para a construção das categorias de análise que irão iluminar o entendimento das vozes e conceitos que serão investigados. 


\section{3. \\ Metodologia}

Neste capítulo serão descritos os caminhos seguidos para que fosse possível desenvolver a análise dos artigos selecionados. Cabe ressaltar inicialmente que a maior dificuldade nesse tipo de análise consiste no grande esforço em separar o objeto de estudo das experiências do investigador. Nesse sentido, o referencial teórico metodológico utilizado na presente análise, foi construído a partir das proposições de Bardin (2011), tratando-se portando de uma análise qualitativa construída por meio da análise de conteúdo.

Bardin (2011) destaca a importância da atitude de vigilância crítica na qual o especialista das ciências humanas deve ter principalmente em decorrência da impressão de familiaridade face ao seu objeto de análise. De maneira geral, o autor vai dizer que a sutileza dos métodos de análise de conteúdo corresponde aos seguintes objetivos:

*Superação da incerteza: o que eu julgo ver na mensagem estará lá efetivamente contido, podendo esta "visão" muito pessoal ser partilhada por outros? Por outras palavras, será a minha leitura válida e generalizável?

*E o enriquecimento da leitura: se um olhar imediato, espontâneo, é já fecundo, não poderá uma leitura atenta aumentar a produtividade e a pertinência? Pela descoberta de conteúdos e de estruturas que confirmam (ou infirmam) o que se procura demonstrar a propósito das mensagens, ou pelo esclarecimento de elementos de significações suscetíveis de "conduzir a uma descrição de mecanismos de que a priori não possuímos a compreensão". (BARDIN, 2011 p. 35)

A análise de conteúdo segundo Bardin (2011) é um método muito empírico, dependente do tipo de "fala" a que se dedica e do tipo de interpretação que se pretende como objetivo. Nessa perspectiva o autor vai dizer que:

Não existe coisa pronta em análise de conteúdo, mas somente algumas regras de base, por vezes dificilmente transponíveis. A técnica de análise de conteúdo adequada ao domínio e ao objetivo pretendidos tem de ser reinventada a cada momento, exceto para uso simples e generalizados, como é o caso do escrutínio próximo da decodificação e de respostas a perguntas abertas de questionários cujo conteúdo é avaliado rapidamente por temas. (BARDIN, 2011 p. 36) 
Segundo o autor citado anteriormente, a análise de conteúdo é um conjunto de técnicas de análise das comunicações. Sendo assim, não se trata de um instrumento, mas de um leque de apretechos; ou, com maior rigor, será um único instrumento, mas marcado por uma grande disparidade de formas e adaptável a um campo muito vasto, o das comunicações.

Dessa forma podemos dizer que o objetivo da análise de conteúdo consiste em:

Apresentar a representação condensada da informação, para consulta e armazenamento; o da análise de conteúdo é a manipulação de mensagens (conteúdo e expressão desse conteúdo) para evidenciar os indicadores que permitam inferir sobre uma outra realidade que não a da mensagem. (BARDIN, 2011 p. 52).

Organização da análise

A análise de conteúdo organiza-se e em torno de três etapas, a saber:

1)A pré-análise;

2)A exploração do material;

3)O tratamento dos resultados, a inferência e a interpretação.

A pré-análise

Segundo Bardin (2011) essa é a fase de organização propriamente dita. De acordo com o autor, geralmente essa fase possui três missões: a escolha dos documentos a serem submetidos à análise, à formulação das hipóteses e dos objetivos e a elaboração de indicadores que fundamentem a interpretação final.

A exploração do material

Essa fase consiste na aplicação sistemática das decisões tomadas, tratamento dos resultados obtidos e interpretação. Para a exploração do material a ser analisado, inicialmente os artigos escolhidos foram agrupados segundo o critério tema e então foram escolhidos os que seriam analisados.

Para Bardin (2011) os resultados brutos são tratados de maneira a serem significativos ("falantes”) e válidos. No caso do presente trabalho, a exploração do material será realizada a partir da análise dos documentos por meio de categorias de análise. Cabe ressaltar que as categorias de análise escolhidas na presente análise, foram desenvolvidas a partir do referencial teórico aqui desenvolvido.

A categorização

Segundo Bardin (2011) a categorização é uma operação de classificação de elementos constitutivos de um conjunto por diferenciação e, em seguida, por 
reagrupamento segundo o gênero (analogia), com os critérios previamente definidos.

A categorização é um processo de tipo estruturalista e comporta duas etapas: O inventário: isolar os elementos;

A classificação: repartir os elementos e, portanto, procurar ou impor certa organização às mensagens.

A figura abaixo representa o desenvolvimento da análise (BARDIN, 2011)

Figura 1 - Análise desenvolvida por Bardin

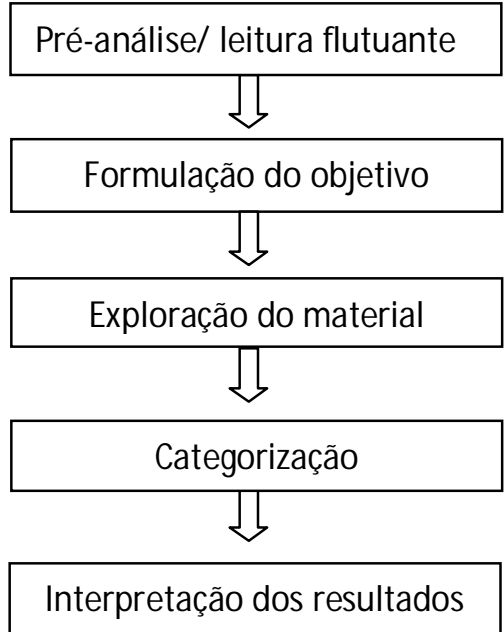

A figura abaixo representa os procedimentos utilizados para análise dos artigos selecionados (caminhos que eu construi) a partir das proposições de Bardin. 
Figura 2 - Caminhos desenvolvidos para a elaboração do trabalho

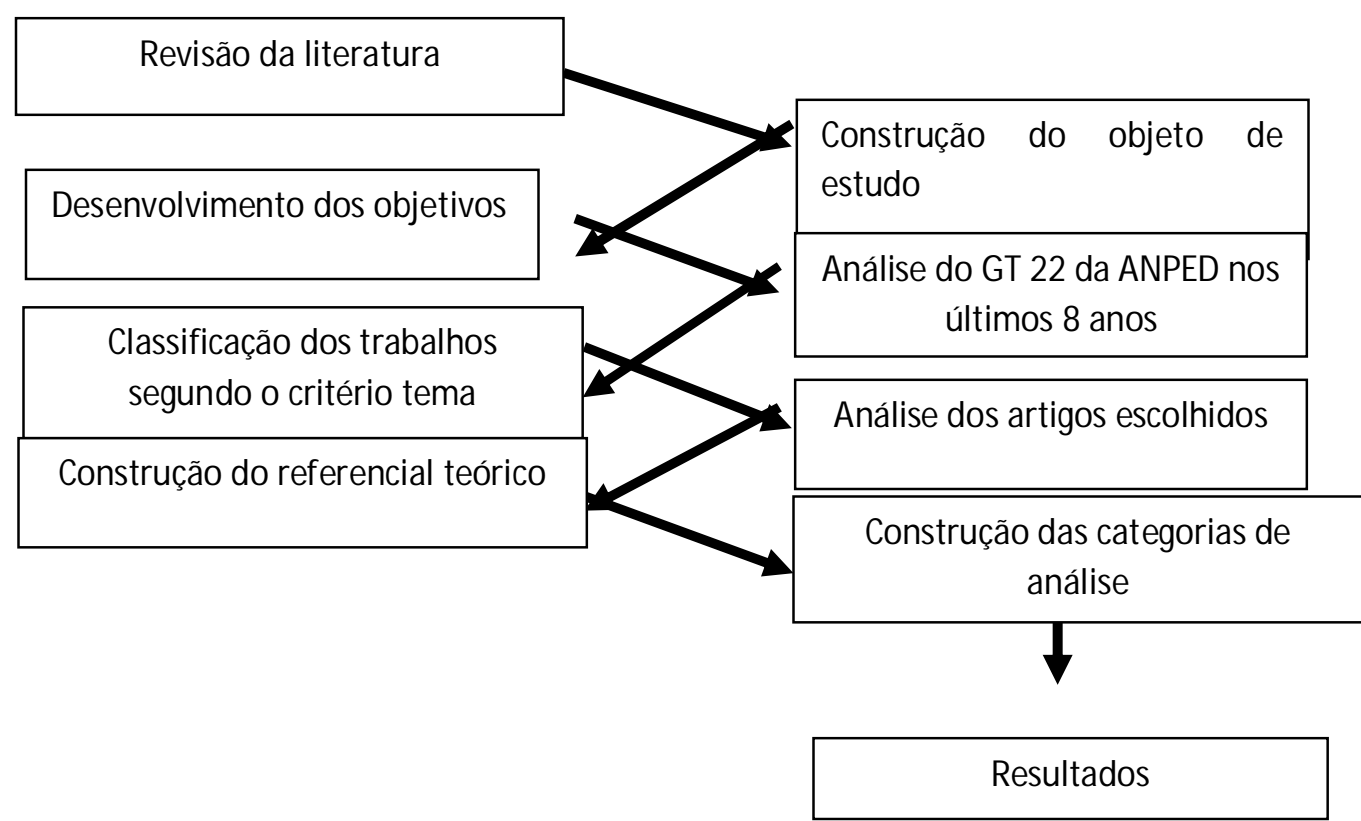

Nesta parte pretende-se apresentar de maneira detalhada de que forma o GT 22 - Educação Ambiental está estruturado. Será a partir do detalhamento da constituição do GT nos seus últimos 8 anos que serão tomadas as decisões para a escolha dos artigos que serão analisados.

Inicialmente foram agrupados todos os trabalhos publicados no GT 22 da Anped nos últimos 8 anos conforme a tabela abaixo.

GT 22 - educação ambiental

Tabela 1 - Número de trabalhos publicados na ANPED nos anos de 2008 até 2013

\begin{tabular}{|l|l|}
\hline Reunião & Número de trabalhos \\
\hline 36 & 7 \\
\hline 35 & 13 \\
\hline 34 & 14 \\
\hline 33 & 16 \\
\hline 32 & 5 \\
\hline 31 & 10 \\
\hline 30 & 10 \\
\hline 29 & $10-$ total de 85 trabalhos \\
\hline
\end{tabular}


Posteriormente cada resumo foi lido de maneira cuidadosa de forma a agrupá-los seguindo o critério tema. Para agrupá-los segundo o critério tema foram levados em consideração a leitura do resumo, o objetivo central do trabalho, além das palavras-chaves. A tabela abaixo apresenta o número de trabalhos em cada eixo temático. 
Tabela 2 - Número de trabalhos publicados por eixo temático

\begin{tabular}{|c|c|}
\hline Eixo temático & $\begin{array}{l}\text { Número de } \\
\text { trabalhos }\end{array}$ \\
\hline Análise do discurso & 2 \\
\hline Educação ambiental e desastres naturais & 1 \\
\hline Perspectiva crítica da educação ambiental & 23 \\
\hline Educação ambiental e mídia & 5 \\
\hline $\begin{array}{l}\text { Educação ambiental e práticas culturais/ estudos } \\
\text { culturais/histórias de vida }\end{array}$ & 8 \\
\hline Educação ambiental na escola pública & 2 \\
\hline Educação ambiental autopoiética & 2 \\
\hline Educação ambiental e mudanças climáticas & 1 \\
\hline $\begin{array}{l}\text { Formação do educador ambiental- formação de } \\
\text { professores }\end{array}$ & 12 \\
\hline Metodologia na pesquisa em educação ambiental & 3 \\
\hline Educação ambiental e empresariado & 3 \\
\hline Educação ambiental e reciclagem (catadores) & 1 \\
\hline $\begin{array}{l}\text { Educação ambiental e políticas públicas - políticas de } \\
\text { educação ambiental }\end{array}$ & 7 \\
\hline Dualismo homem-natureza & 3 \\
\hline Impactos socioambientais & 1 \\
\hline Projetos de educação ambiental nas escolas & 3 \\
\hline Ecosofia & 2 \\
\hline Sustentabilidade & 1 \\
\hline Práticas pedagógicas-docentes & 2 \\
\hline Educação ambiental e ética (valores) & 1 \\
\hline Institucionalização da educação ambiental & 1 \\
\hline Aprendizagem & 4 \\
\hline Produção científica em EA & 1 \\
\hline EA e currículo - livro didático & 5 \\
\hline EA e transdiciplinaridade & 2 \\
\hline Educação ambiental na perspectiva pós-moderna & 2 \\
\hline Educação ambiental e cidadania & 1 \\
\hline
\end{tabular}


Conforme pode ser observado na tabela anterior, a pluralidade de temas dentro do GT é bastante ampla, totalizando 27 eixos temáticos. Entretanto podemos notar um grande número de trabalhos que se enquadram no eixo intitulado perspectiva crítica da educação ambiental. Dessa forma, considerando o número de trabalhos (23) significativo para uma análise, o trabalho será estruturado de forma a analisar o mesmo. Embora o eixo temático apresente 23 trabalhos, apenas 18 foram disponibilizados na internet na íntegra e 5 trabalhos só apresentavam o resumo. Sendo assim, serão analisados os 18 disponíveis na íntegra.

\section{1.}

\section{Eixos temáticos}

\section{Análise do discurso}

Contempla trabalhos que problematizam o discurso da crise ambiental na atualidade. Envolve trabalhos de natureza empírica com base em discussões acerca do medo em Zigmunt Bauman; biopoder/ biopolítica em Michel Foucault. Engloba também trabalhos que analisam como o discurso consciente tem governado sujeitos.

\section{Educação ambiental e desastres naturais}

Aborda os problemas decorrentes de inundações e escorregamentos bem como o enfoque comportamentalista e tecnocrático nos processos de prevenção de desastres naturais.

\section{Perspectiva crítica da educação ambiental}

Trabalhos que articulam a produção em educação ambiental numa perspectiva crítica voltada para uma participação cidadã, para a construção de sociedades socialmente justas num sentido de educação transformadora e emancipatória. Apresentam como aporte teórico trabalhos embasados em Karl Marx. Apresenta ainda trabalhos que buscam um sentido libertário de educação e que discutem a autonomia dos sujeitos.

\section{Educação ambiental e mídia}

Discute como as questões ambientais são tratadas na televisão. Trabalham temas como desenvolvimento sustentável. Inclui trabalhos de natureza empírica que operam em alguns casos com o conceito de biopoder a partir de Michel Foucault. Discute os desafios da educação e analisam como o tema da crise 
ambiental tem entrado em pauta na sociedade atual, sobretudo nas mídias. Discute também o papel da educação frente as mudanças climáticas globais.

Educação ambiental e práticas culturais/ estudos culturais/ histórias de vida

Trabalhos que discutem a centralidade da cultura nos processos de significação da natureza. Defendem a multiplicidade de modos de entender, narrar e estabelecer relações com a natureza. Trabalhos de natureza empírica que se debruçam sobre narrativas. Buscam identificar espaços de aprendizagem comunitária. Além disso, discutem propostas de ações educativas e propostas metodológicas.

\section{Educação ambiental na escola pública}

Trabalhos que abordam a penetração da educação ambiental na escola pública.

\section{Educação ambiental autopoiética}

Trabalhos de natureza empírica, cartografam e problematizam saberesfazeres socioambientais. Buscam pensar a constituição da educação ambiental autopoiética inspirada nos estudos de Humberto Maturana, como invenção de si e do mundo, com experiências e práticas culturais cotidianas que emergem entre tensões, conflitos e negociações com as redes de conversações, criando relações de coletividade e solidariedade.

\section{Formação do educador ambiental/ formação de professores}

Trabalhos que reconhecem a educação ambiental como um tema para a alfabetização contextualizada. Pesquisas que relacionam a educação ambiental na formação de professores para produzir um conhecimento emancipatório. Apresentam ainda trabalhos que pensam a formação do educador a partir de uma perspectiva dialógica e relacional, ancorada no pensamento freiriano.

\section{Metodologia na pesquisa em educação ambiental}

Pesquisas relacionadas à consolidação de procedimentos teóricometodológicos que sustentem a construção de indicadores socioambientais para avaliação de programas e projetos em educação ambiental. Incluem-se também trabalhos que buscam fazer uma aproximação entre Gadamer e Paulo Freire a fim de contribuir para a compreensão da fenomenologia hermenêutica enquanto possibilidade metodológica de pesquisa na educação ambiental.

\section{Educação ambiental e o empresariado}


Pesquisas que buscam conhecer a exploração de minerais e as repercussões na sociedade. Investigam ações educativas das empresas, confrontando-os com seus discursos e práticas. Há trabalho ainda que analisa a parceria entre empresas e escolas através de projetos de educação ambiental.

\section{Educação ambiental e reciclagem}

Busca compreender os processos sociais de aprendizagem social vivenciados por catadores. Pesquisa de cunho etnográfico.

Educação ambiental e políticas públicas/ políticas de educação ambiental

Busca analisar programas de educação socioambiental junto a docentes. Trabalhos que visam analisar a proposta e a gestão de programas municipais de educação ambiental. Analisam políticas públicas de educação ambiental.

\section{Dualismo homem versus natureza}

Busca desligitizar a idéia de homem excluído da natureza. Discute os paradigmas de natureza na atualidade.

\section{Impactos socioambientais}

Trabalho que discute o impacto da construção do Arco Metropolitano do Rio de Janeiro sobre a população local, sendo o arco um objeto social de desterritorialização forçada.

\section{Projetos de educação ambiental nas escolas}

Problematiza o crescimento dos trabalhos com projetos nas escolas, uma vez que os projetos segundo alguns autores se limitam apenas à questão metodológica de maneira bem simplificada. Há autores que concebem os projetos como uma forma de oportunizar a formação de professores investigadores, inovadores e críticos, além de fornecer aos alunos condições para observar, conhecer, refletir e construir.

\section{Ecosofia}

Trabalhos baseados na ecosofia de Guattari, pensamento complexo em Morin, a psicogenética de Wallon e as reflexões de Maturana sobre educação e no conceito de educação interpretativa de Corsaro. Trabalham como a natureza é apresentada às crianças pela escola, e também traz reflexões sobre as práticas pedagógicas e sua pertinência na construção de uma educação condizente com as atuais necessidades planetárias.

\section{Sustentabilidade}


Analisa os limites e potencialidade da educação para a sustentabilidade

\section{Práticas pedagógicas docentes}

Pesquisam a (dês) hierarquização dos saberes. Buscam a formulação de procedimentos pedagógicos democráticos.

\section{Educação ambiental e ética}

Pesquisa de caráter qualitativo com objetivo de verificar as valorações atribuídas aos animais por professores das séries iniciais do Ensino Fundamental.

\section{Institucionalização da educação ambiental}

Trabalho que discute a institucionalização da educação ambiental, a partir da sua implementação no Brasil.

\section{Aprendizagem}

Tem como foco trabalhos que analisam como a educação ambiental pode contribuir na aprendizagem. Há trabalhos que tomam a idéia de Maturana do amor como uma atitude epistemológica para a construção de uma aprendizagem que privilegie a cooperação e não a competição. Trabalhos que buscam ainda compreender e como qualificar a contextualização e ambientalização dos processos de ensinoaprendizagem.

\section{Produção científica em educação ambiental}

Analisa a produção cintífica em educação ambiental no período de 2001 a 2009 através dos trabalhos apresentados nas reuniões anuais da ANPEd e nos encontros da ANPPAS e nos EPEAs. A metodologia integra levantamento e análise dos trabalhos publicados quanto às ênfases temáticas e as características dos autores

\section{Fabulação em Deleuze}

Trabalho que deseja uma escritapesquisa em experimentação, ressoando com o conceito de fabulação em Deleuze e(m) imagens que se propõem em exploração de sentidos para pensar uma outra educação, outro ambiente.

\section{Educação ambiental e transdiciplinaridade}

Discutem a possibilidade de que a educação ambiental seja entendida a partir da abordagem da ética complexa e possa ser praticada de forma transdiciplinar.

\section{Educação ambiental na perspectiva pós-moderna}


Trabalho que busca construir diálogos entre campos da ecologia política e da educação ambiental, com ressonâncias do pensamento de Nietzche na obra de Deleuze e de seus interlocutores.

\section{Educação ambiental e cidadania}

Discute a qualidade do ar no Brasil e a importância da educação ambiental enfocando a cidadania, partindo do princípio de que todos temos direito a um ar saudável.

\section{2.}

\section{Categorias de análise}

A seguir serão apresentadas as categorias de análise. As categorias foram elaboradas a partir do modelo de Bardin (2011), explicado anteriormente. Dessa forma, foram construídas categorias de análise formuladas a partir dos conceitos discutidos no capítulo teórico e que serão brevemente retomados a seguir. Dessa forma, buscou-se construir categorias que fossem capazes de analisar os artigos à luz do que entendemoscomo Teoria Crítica da Educação Ambiental neste trabalho.No que se refere à escolha dos autores utilizados, os mesmo foram escolhidos a partir da revisão da literatura. Dessa forma, ainda na elaboração do projeto da presente dissertação, pude mapear na literatura as principais obras e autores utilizados no Campo de investigação que adotam uma perspectiva crítica de educação ambiental.

No que diz respeito à construção das categorias, as mesmas foram elaboradas a partir da identificação de conceitos e/ ou categorias que fossem capazes (de forma ampla) de explicar o que estamos chamando de educação ambiental crítica. Nesta pesquisa, como pôde ser visto no capítulo teórico, o principal autor que orienta as discussões aqui travadas é Leff. Sendo assim, o autor foi escolhido por ser um dos grandes teóricos contemporâneos a problematizar o que é o ambiente, bem como o saber ambiental. Pelo que se pôde notar, sua investigação tem início, sobretudo a partir dos anos sessenta em resultado da crise de civilização. Leff busca construir uma articulação das ciências de forma a construir um conhecimento científico que questiona o atual modelo de racionalidade.

Dessa maneira, a proposta do trabalho é tentar identificar nos artigos a serem analisados, as concepções de educação ambiental crítica. Sendo assim, o 
esforço do trabalho consiste em classificar as categorias dos autores, a partir das categorias aqui desenvolvidas para no final chegar a uma conclusão, que deverá responder a seguinte pergunta: Os artigos publicados na Anped, nos últimos 8 anos do GT 22 (educação ambiental) que se julgam críticos, são realmente críticos? Para obtermos essa resposta, serão analisados e classificados os textos em categorias e posteriormente serão interpretados.Inicialmente, será construída uma tabela de forma a classificar os artigos, e posteriormente as categorias serão agrupadas para que possamos compreender a totalidade das concepções de educação crítica apresentadas na Anped. A seguir, apresento as categorias que foram selecionadas para a presente análise.

\section{Educação ambiental}

Entendida de forma diferente das outras pedagogias, a educação ambiental segundo Carvalho (2008) se apresenta como sendo uma resposta da educação à preocupações da sociedade com a questão ambiental, o que torna fundamental entender a educação ambiental dentro do contexto dos movimentos ecológicos. Para a autora os movimentos ecológicos contribuíram para levar à crítica ao capitalismo industrial e promover um ideário emancipatório. Dessa forma, buscase compreender qual a concepção de educação ambiental que os artigos utilizam.

\section{Educação ambiental crítica}

Parte de uma visão que rompe com as dicotomias homem versus natureza (construída através da alienação capitalista). Além disso, a educação ambiental crítica deve ser capaz de fomentar posturas que não estimulem o consumismo desenfreado sem refletir suas conseqüências para o meio ambiente. Para Loureiro (2002) a educação ambiental é uma práxis que tem por finalidade a construção de valores, conceitos, habilidades e atitudes que possibilitem o entendimento da realidade de vida.

Na concepção de Loureiro (2003) é preciso buscar compreender e adotar um corpo teórico que seja compatível com uma educação ambiental transformadora. Para esse autor o marxismo é capaz de fornecer subsídios consistentes para alcançar uma educação ambiental transformadora, ou seja, um pensamento pautado na criticidade e na ruptura com o conhecimento historicamenteconstruído e pautado nas leis orgânicas e atomísticas da ciência moderna. É necessário abrir novos conhecimentos que se pautem nas atividades humanas. Neste sentido, essa 
categoria de análise será capaz de revelar o que os autores dos artigos selecionados entendem como educação ambiental crítica.

\section{Recliclagem}

Para Loureiro (2010) a reciclagem tem que ser pensada como qualquer outra categoria ou relação. Ou seja, para ser efetiva segundo os interesses ambientalistas democráticos, é preciso ser problematizada, articulada com aquilo que define (estilos de vida, padrão de consumo e produção, quem se apropria dos benefícios da reciclagem, etc.) e realiza para "a transformação das relações e, portanto da realidade". (LOUREIRO, 2010 p. 75). Sendo assim, a reciclagem deve ser pensada de maneira a questionar o padrão de consumo e de apropriação da natureza, indo além do simples processo de reutilização de materiais. É necessário ir à raiz do problema e não construir formas de contorná-lo.

\section{Epistemologia ambiental}

Leff parte de uma crítica ao modelo de ciência cartesiana, do pensamento único e da falta de diálogo entre os diferentes campos do conhecimento para a construção de um saber ambiental.

Nesse sentido, a interdisciplinaridade deve incluir a construção de um novo paradigma científico que trate da questão ambiental, destacando a necessidade de um pensamento complexo.

Essa categoria é fundamental para que possamos compreender a natureza do saber ambiental. Sendo assim, numa visão crítica de educação ambiental, torna-se crucial romper com a lógica clássica da ciência que não articula as diferentes áreas do conhecimento e não reconhece o conhecimento historicamente construído.

\section{Racionalidade ambiental}

Rompe com a lógica que concebe e compreende a Natureza a partir de uma perspectiva que coloca o homem no centro do conhecimento do mundo, dando início a uma racionalidade que irá comprometer o meio ambiente. Nesse sentido, uma educação que se quer crítica deve conceber a problemática ambiental de forma não neutra e nem alheia aos interesses econômicos e sociais, tendo sua gênese no modo de produção capitalista, na racionalidade econômica. Nesse sentido, entendemos que uma educação ambiental que se intitule enquanto crítica está implicada com uma concepção que não separa o homem da Natureza.

\section{$O$ conceito de natureza}


Para Gonçalves, a Natureza em nossa sociedade se define por aquilo que se opõe à cultura. A cultura é tomada como algo superior e que conseguiu controlar e dominar a Natureza. Nesse sentido, concebemos o conceito de Natureza numa perspectiva crítica onde não haja a separação homem/ Natureza, uma vez que essa é uma característica marcante do pensamento ocidental.

\section{3.}

\section{Análise dos artigos}

No artigo intitulado "Discutindo a práxis participativa: concepções e contribuições à educação ambiental crítica da Baixada Fluminense", a autora destaca a importância da EA como estratégia para a formação de indivíduos particípes na construção de uma sociedade sustentável, socialmente justa e ecologicamente equilibrada. No entanto, a autora faz uma crítica à fragmentação e descontextualização que caracteriza práticas conservadoras na EA.

A autora busca respostas para os desafios enfrentados na implementação da EA e assume uma perspectiva crítica de transformação da realidade. A mesma também demonstra preocupações acerca da sociedade pouco participativa e estratificada. Neste sentido, Oliveira (2012) busca práticas pedagógicas contrahegemônicas de forma a intervir na realidade contribuindo para o enfrentamento da grave crise socioambiental.

Outra crítica que pôde ser observada, diz respeito à uma concepção que enfatiza a dimensão ecológica da crise deslocada da dimensão social. Sendo assim, seu intuito consiste em expressar a EA numa perspectiva de educação que incorpora os sujeitos sociais e permite estabelecer uma prática pedagógica emancipatória e transformadora. Busca também superar a dicotomia homem/ Natureza. Em alguns momentos do seu texto a autora afirma a necessidade da construção de uma EA ambiental complexa que supere o olhar ingênuo acerca do tema. Entretanto, em seu texto, não fica claro qual a concepção de EA ambiental complexa a mesma está adotando.

No texto intitulado "Ações socioambientais em uma comunidade cooperada: trabalho e conflito como categorias centrais na práxis" a autora desenvolve uma pesquisa de caráter longitudinal (doutorado). A pesquisa foi realizada inicialmente junto a uma cooperativa de recicladores de resíduos sólidos no município de Mesquita, Baixada Fluminense - RJ, a Coopcarmo. Seu trabalho tem por objetivo 
analisar o processo de constituição de práticas participativas populares estabelecidas entre a cooperativa de trabalho e o município de Mesquita, no que concerne às questões socioambientais entre 2000-2010. Este processo carrega o surgimento de vários outros movimentos participativos e a geração de políticas públicas em torno das questões da educação ambiental.

Em seu texto, ao falar da educação formal na escola, a Santos (2010) faz uma crítica à educação ambiental desenvolvida na escola e afirma que:

A educação consolida-se como sendo não ambiental, desconsiderando as relações homem-natureza, e contraditoriamente, passa a contribuir consideravelmente com o desequilíbrio dessas relações. (SANTOS, 2010 p. 6)

A partir da leitura do artigo fica clara a postura crítica adotada pela autora. Embora não aborde algumas das categorias que estão sendo analisadas nesse trabalho, a sua pesquisa oferece uma relevante contribuição ao campo da educação ambiental, uma vez que problematiza a categoria "trabalho" e sua articulação com os sujeitos envolvidos no processo da reciclagem.

Em "Caminhos para a inserção da dimensão socioambiental na formação inicial de educadores: possibilidades e obstáculos encontrados”, Queiroz (2012) desenvolve uma pesquisa que objetiva investigar como se dá no processo formativo a dimensão socioambiental em curso de formação de educadores para a consolidação da Educação Ambiental crítica na formação docente.

Para a mesma, o capitalismo é o responsável pelos problemas ambientais. Nesse sentido, compreende a crise enquanto o resultado do atual modelo capitalista que cria necessidades e estimula o consumismo. Além disso, a autora comunga com idéias expostas no referencial teórico da presente pesquisa, na medida em que rejeita o pensamento único, bem como as verdades universais, afirmando a necessidade de acolhermos as múltiplas dimensões e perspectivas. Além do atual modelo capitalista de produção, o texto responsabiliza a visão antropocêntrica e utilitarista da Natureza pela crise ambiental, destacando a necessidade de problematizar a cultura dominante da modernidade.

Problematiza também as relações entre os países pobres do Sul e os ricos do Norte, que muitas vezes sugerem o controle demográfico como solução para os problemas ambientais. Faz uma crítica dura às posturas neomalthusianas e aponta a distribuição injusta das riquezas como a verdadeira responsável pela crise socioambiental. 
Acredita que a EA é reconhecida como uma das principais formas de superação da realidade em crise. Aponta os entraves que impedem a construção da EA nas escolas ao afirmar que a escola se apresenta de forma tradicional, demarcada por uma visão cartesiana, disciplinarizada e bancária. Apoiada no materialismo histórico e dialético a autora critica também a disciplinarização pautada no pensamento linear.

Queiroz (2012) descobre que o enfoque interdisciplinar não é contemplado na formação de professores. Em suas palavras afirma que "a fragmentação/ especialização curricular na universidade representa um dos limites para a inserção da dimensão socioambiental de forma interdisciplinar". (QUEIROZ, 2012 p. 14)

Por último a mesma faz um clamor à atual necessidade de que as universidades estejam preparadas para formar educadores ambientais e não apenas profissionais que reproduzirão conteúdos universalmente construídos. Em suas palavras:

Consideramos que, para a consolidação de uma sociedade mais justa e ambientalmente sustentável, é urgente que a universidade forme não apenas professores, mas o educador ambiental que, como líder, sinta-se capaz de proporcionar um processo educativo que busque a transformação da realidade no sentido de superar as práticas educacionais comportamentalistas e individualistas, presas ao reducionismo e à exclusão da lógica capitalista. (QUEIROZ, 2012 p.15)

Em "Formação de redes: uma dimensão pedagógica para a sustentabilidade", as autoras apresentam elementos da Teoria da Complexidade, da Educomunicação e da Educação Ambiental referenciada pela Teoria Crítica, com vistas a uma aproximação que contribua para a discussão teórica que ultrapasse a abordagem disciplinar, tendo como viés principal a dimensão pedagógica da formação de redes para a sustentabilidade. Nesse sentido, o trabalho pretende apontar para a superação de uma limitada abrangência do fenômeno complexo, com algumas indicações teóricas iniciais que objetivam balizar a atuação dos atores sociais e consolidar uma nova prática social em rede, capaz de contribuir para a construção de uma realidade socioambiental sustentável. (OLABARRIAGA; NEFFA, 2010 p. 2).

Dessa forma, as autoras compreendem as redes como um fenômeno social inovador e de grande potencial educativo. Para as mesmas, as redes ainda são pouco utilizadas nas práticas pedagógicas, e seu esforço consiste justamente em 
tornar visível o uso das redes no ato educativo. Sendo assim, seu principal objetivo consiste viabilizar ações coletivas que fomentem alternativas sustentáveis à crise vivenciada na contemporaneidade.

Em resumo, as autoras buscam oferecer subsídios para promover novas práticas sociais. Do ponto de vista metodológico o trabalho oferece caminhos para que sejam superados os problemas ambientais. Cabe ressaltar que se trata de um trabalho teórico crítico, mas que não deixa claro de que forma é possível utilizar as redes para a superação dos problemas ambientais, muito embora o trabalho defina claramente o conceito de rede.

O texto se apresenta de maneira crítica uma vez que o trabalho busca construir conhecimentos que sejam capazes de promover a emancipação dos sujeitos. Além disso, no trabalho é desenvolvida uma crítica a forma da ciência moderna que se pauta numa concepção de homem e Natureza separados, além da crítica à concepção antropocêntrica de Natureza.

Embora o artigo não aborde de maneira direta o tema da reciclagem, podemos notar um olhar crítico das autoras sobre o assunto. Elas afirmam que uma ação pedagógica crítica é aquela que promovem ações conscientes. Em suas palavras temos:

Têm-se como intenção pedagógica crítica a constituição de um espaço que propicie a passagem de ações inconscientes e reprodutoras de práticas hegemônicas para uma prática consciente diferenciada, capaz de problematizar a realidade, questionando-a e transformando os sujeitos sociais/ coletivos em atores proponentes e construtores de novos caminhos. (OLABARRIAGA; NEFFA p.13)

“A imprescindível adoção da Teoria Crítica na formação do educador ambiental: um caminho para o enfrentamento da crise socioambiental e para a transformação da relação desigual homem-sociedade-natureza".

O texto apresenta uma discussão teórica acerca da formação de educadores em sentido lato, com contribuições de Tardif (2002), Nóvoa (2001), Schon (1992), Giroux (1997, 1999), dentre outros, acerca da formação de educadores ambientais em sentido estrito, com contribuições de Guimarães (2004, 2005, 2006), Loureiro (2005, 2006, 2009), Layrargues (2005) e Tozoni-Reis (2002), dentre outros, "buscando delinear as imbricações entre esses dois vieses da educação”. (RODRIGUES, 2012 p.1)

A autora busca na Teoria das Representações Sociais (TRS), do campo da psicologia social e no estudo das ideologias do campo do marxista, apontar suas 
interlocuções para chegar ao objetivo do seu estudo, que consiste em chegar à formação do educador ambiental crítico. Seu estudo foi realizado com educadores participantes da construção da política municipal de educação ambiental de Mesquita- RJ e o grupo de mestrandos em educação de uma universidade federal. O artigo apóia-se no materialismo histórico dialético com o objetivo de aprofundamento teórico reflexivo para a educação ambiental.

Compreendemos o trabalho de forma crítica uma vez que o mesmo apresenta argumentos que responsabilizam o modo de produção capitalista pelos problemas ambientais. Além disso, fica claro que sua concepção de EA crítica refere-se ao confronto com o padrão societário vigente e de tentativa de implementação de uma sociedade alternativa a esta.

"O trabalho cooperativo no enfrentamento dos limites que o tempo hegemônico impõe à prática de uma educação ambiental emancipatória”. O trabalho apresenta uma reflexão sobre a metodologia de trabalho cooperativo entre museus e escolas como estratégia que fortalece processos de construção de uma cultura da cooperação em ações educativas. O trabalho de educação ambiental crítica, busca refletir sobre as causas, consequiências e possíveis soluções de problemas socioambientais de territórios vulnerabilizados. Seu referencial teórico apóia-se no materialismo histórico dialético. Os autores utilizaram uma técnica de tabulação dos dados qualitativos de natureza verbal conhecido como discursos do sujeito coletivo (DSC). Essa técnica, segundo os autores, permite apreender o pensamento de uma coletividade, compondo textos a partir dos discursos desses indivíduos.

O trabalho busca estratégias que sejam emancipatórias e desenvolve uma crítica à lógica individualista, consumista, mercantilizada e excludente.

"Da evolução da concepção de natureza e de homem na ambivalência de uma educação ambiental crítica", trata-se de um trabalho teórico onde é apresentada a evolução da concepção de homem em combinação com a evolução de Natureza. O artigo desenvolve uma crítica à visão dicotômica de mundo baseada na separação homem/ Natureza, além da ocidentalização do mundo. No que diz respeito à concepção mecanicista da Natureza, o texto afirma que a fábrica, um universo de movimentos mecânicos, representa uma miniatura da engrenagem da Natureza. 
O texto concebe os problemas ambientais enquanto resultado das práticas que separam homem da Natureza, conforme fica claro no trecho abaixo:

(...) entende que as compreensões de homem e natureza que informam as práticas concretas dos homens são responsáveis pelos resultados danosos a esses mesmos homens e à natureza, com especificidade a partir de Decartes quando as dicotomias homem-natureza, matéria-espírito, objeto-sujeito passam a se constituir em bases do pensamento moderno, inaugurando uma nova visão de natureza. (VASCONCELLOS; LOUREIRO, 2012 p.1)

Os autores afirmam que sua abordagem é crítica, pois entende que as compreensões de homem e Natureza que informam as práticas concretas dos homens são responsáveis pelos resultados danosos a esses mesmos homens e à Natureza.

Antes a Natureza era mitificada, hoje torna-se dessacralizada e passa a ser entendida enquanto mero recurso a ser transformada e resultar em riquezas. No pensamento dos autores isso ocorre a partir do desenvolvimento das técnicas, inscrito na revolução técnico-científica. Seu objetivo é "fazer com que a educação ambiental transcenda uma leitura conservadora sobre a problemática ambiental sob o modo de produção capitalista". (VASCONCELLOS; LOUREIRO; QUEIROZ, 2012 p.3)

O artigo apresenta uma síntese da evolução do conceito de Natureza. Sobre esse tema, destacam que a visão gravitacional significa a dessacralização da Natureza. A Natureza deixa de ser morada de Deus e passa a ser concebida como tudo que se expressa por um conteúdo físico matemático.

No artigo intitulado "Uma aproximação entre Gadamer e Paulo Freire como contribuição para refletir sobre a pesquisa em educação" os autores iniciam sua problemática afirmando que atualmente o cenário que se configura na pesquisa em Educação Ambiental no Brasil e no mundo é de ampliação do campo teórico. Acreditam que no momento atual há uma busca de uma identidade teóricoepistemológica do campo. Consideram a Educação Ambiental crítica como aquela que visa proporcionar uma leitura de mundo mais complexa, que contribua no processo de transformação de uma realidade.

Os autores acreditam que a fenomenologia hermenêutica seja "compatível" com a Educação Ambiental crítica, emancipatória e transformadora. Entretanto, os mesmos sinalizam que a fenomenologia hermenêutica sofre uma crítica por não 
ter como finalidade a transformação da realidade social, uma vez que se debruça sobre os fenômenos e sentidos.

O objetivo do artigo analisado consiste em realizar uma aproximação entre Gadamer e Paulo Freire com vistas a aproximá-los da Educação Ambiental crítica. Os autores informam que a fenomenologia hermenêutica se desenvolve a partir de autores que visam à superação da dicotomia sujeito-objeto e ser humano-mundo.

Para Gadamer a hermenêutica é um campo filosófico que procura explorar o processo de compreensão humana em suas manifestações mais extremas. A originalidade de sua obra segundo os autores está na concepção de que o conhecimento não é fruto da pura subjetividade transcendental, mas se dá na historicidade e na linguagem. (IARED; TULLIO; OLIVEIRA, 2012).

Em Freyre, o diálogo aparece como categoria central na superação das racionalidades dominantes. $\mathrm{O}$ autor desenvolve sua teoria a partir da dialética de Hegel e da dialética de Marx. Após apresentar a centralidade das teorias dos autores mencionados, o artigo apresenta a uma concepção de qual seria o papel de uma Educação Ambiental e destacam que:

Na nossa compreensão, uma das tarefas da Educação Ambiental seria pensar um novo modo de ser, um novo modo de nos relacionarmos como seres históricos, dentro de uma tradição para compreendermos o passado, o presente e fundarmos uma nova perspectiva de futuro. O conceito de horizontes, proposto por Gadamer é uma contribuição para esse processo. (IARED; TULLIO; OLIVEIRA, 2012 p.8)

Afirmam também que a ambientalização diz respeito ao processo de internalização da questão ambiental pelos sujeitos e a hermenêutica ajudaria a apreender a internalização da questão ambiental. Acreditam que a superação do desafio ambiental exige a busca de novos paradigmas. Consideram o diálogo como essencial nesse processo. Um dos objetivos da Educação Ambiental é a formação crítica. Apoiam-se na idéia de pré-compreensão (Gadamer) e de consciência crítica (Freire), afirmando que "a hermenêutica traz a perspectiva de interpretar, de produzir sentido e da possibilidade de separar o sujeito do mundo". (IARED; TULLIO; OLIVEIRA, 2012 p.12)

Concebem essa abordagem importante, uma vez que trata da relação do ser humano com o mundo. Ou seja, aborda as vivências e sentimentos humanos com o meio ambiente. Por fim, os autores destacam que a abordagem hermenêutica e a racionalidade dialógica se apresenta como uma perspectiva metodológica capaz de contribuir no campo da Educação Ambiental. 
Em suma, crêem que a relação sujeito-mundo se constrói a partir da linguagem e nesse sentido a fenomenologia hermenêutica é capaz de interpretar a experiência vivida.

Em "Fundamentos teóricos para uma pesquisa crítica da Educação Ambiental: algumas contribuições”, a autora inicia o debate destacando a dimensão política da Educação Ambiental. Utiliza o termo política uma vez que a mesma não é neutra e possui intencionalidade. Adverte ainda que o seu caráter político não implica necessariamente em uma Educação Ambiental crítica. Isso porque ela pode não ter o caráter transformador além de serem simplesmente reprodutoras.

A autora nos informa ainda que ao se tratar de uma ação política, a mesma apresenta diferenças conceituais. Nas palavras de Tozoni- Reiz (2007), essas diferenças podem ser sintetizadas em alguns grandes grupos como pode ser visto no fragmento baixo:

A Educação Ambiental promotora de mudanças de comportamentos ambientalmente inadequados - de fundo disciplinatório e moralista-; a Educação Ambiental para a sensibilização ambiental de fundo ingênuo e moralista-; e a Educação Ambiental centrada na ação para a diminuição dos efeitos predatórios das relações dos sujeitos com a natureza- de caráter ativista e imediatista; a Educação Ambiental centrada na transformação de conhecimentos técnicocientíficos sobre os processos ambientais - de caráter racionalista e instrumental; e a Educação Ambiental como processo político, crítico, para a construção de sociedades sustentáveis do ponto de vista ambiental e social - a Educação Ambiental transformadora e emancipatória. (TOZONI - REIS, 2007 p. 2)

A categoria eleita no artigo foi a Educação Ambiental crítica, transformadora e emancipatória. Defende a coletividade no processo de compreensão do mundo em direção à sustentabilidade. Adota o marxismo como referencial teórico prático. Dessa forma o texto apresenta uma breve reflexão sobre o referencial marxista.

Sobre a pedagogia crítica Tozoni-Reis (2007 p.13) informa que:

(...) a pedagogia crítica diz respeito à teoria e AA prática do processo de aproximação de conhecimentos, idéias, conceitos, valores, símbolos, habilidades, hábitos, procedimentos e atitudes para a emancipação dos sujeitos e a transformação das relações de dominação nas sociedades desiguais.

As categorias essenciais para a compreensão e para a ação educativa são a totalidade, concreticidade, historicidade e contraditoriedade, uma vez que entende que essas categorias são responsáveis na apreensão da realidade. Respaldados em Marx, partem da crença de que o homem tem no trabalho a atividade vital. $\mathrm{Na}$ 
mesma direção concebe a relação homem-Natureza construída pelo trabalho. A partir da construção desse raciocínio, a autora percebe que a Educação crítica e transformadora diz respeito à superação da condição de alienação dos homens, resultante da divisão do trabalho.

Compartilhando do pensamento marxista, Tozoni-Reis (2007) vai dizer que a alienação emerge da divisão social do trabalho. É por meio dessa alienação inserida nas condições de exploração que a condição de pessoa humana se constrói. Ou seja, a divisão do trabalho produz sujeitos alienados transformando as relações entre pessoas em relações entre coisas. Acrescenta ainda que o conceito de ideologia é crucial na concretização desse processo. Sobre a ideologia, além do seu conceito que foi discutido no artigo, a autora destaca que:

A ideologia, portanto, só se realiza na sociedade de classes, pois sua função é a manutenção da exploração e da dominação de pessoas sobre pessoas, embora sua principal estratégia seja a negação da existência das classes sociais. (TOZONI REIS, 2007 p.7 )

Dessa forma, compreende que ideologia e alienação são conceitos fundamentais do pensamento marxista na construção de uma pedagogia crítica. Destaca ainda que a "consciência da condição alienada" não é suficiente para superar a alienação, conforme o fragmento abaixo aponta:

Nesse sentido, o enfrentamento da ideologia e da alienação, são fundamentais para o processo educativo, se faz pela práxis: ação refletida, pensada concreta e historicamente, praticada eivada de teoria. (TOZONI - REIS, 2007 p.8)

Em suma, reafirma que a educação crítica é essencialmente política, democrática, emancipatória e transformadora. Apresenta também o pensamento pedagógico no Brasil destacando os movimentos da pedagogia tradicional, pedagogia nova e pedagogia crítica.

Dessa forma, o principal objetivo do artigo, consistiu em oferecer contribuições à construção de uma educação ambiental capaz de promover a equidade, democracia, justiça e emancipação dos sujeitos.

"Os desafios e potencialidades da articulação entre educação ambiental e prevenção de desastres naturais no Brasil" o trabalho desenvolve uma reflexão sobre os desafios e potencialidades da articulação entre educação ambiental e prevenção de desastres naturais. Os autores relacionam os desastres naturais às questões socioambientais destacando a influencia da ocupação humana (resultado da segregação socioespacial), o modo de vida na contemporaneidade, dentre 
outros fatores. Nesse sentido, o trabalho busca compreender de que forma o enfoque crítico pode atuar na superação dessa tendência.

Os autores destacam a criação da Lei $\mathrm{n}^{\circ} 12.608$ de 10 de abril de 2012, que dispõe sobre a política nacional de proteção e defesa civil. Essa lei foi desenvolvida em resposta aos acidentes de 2011 na região serrana do Rio de Janeiro.

Compreendem o risco como resultado do processo de modernização e desenvolvimento científico. Destacam que a secretaria nacional de defesa civil, locada no Ministério da Integração, junto com as coordenadorias estaduais de defesa civil, realiza oficinas preparatórias para a chuva de verão. O que os autores identificam é que não se propõe ir à raiz do problema, mas sim fazer com que a população conviva com o risco.

De acordo com os autores, a Política Nacional de Educação Ambiental (PNEA), Lei 9.795 de 27 de abril de 1999, tem entre seus objetivos o desenvolvimento de uma consciência sobre a problemática ambiental e social, destacando que essa consciência deve ser crítica e não voltada simplesmente para a adoção de comportamentos ambientalmente adequados.

De acordo com o texto, diversas publicações têm buscado definir e defender um paradigma crítico transformador. Entretanto, os autores notaram a predominância de uma educação adestradora em propostas oficiais voltadas para o meio ambiente.Apoiados em Beck (1992), os autores vão dizer que o risco se manifesta de três formas na sociedade moderna. A primeira diz que a sociedade se edificou por meio da apropriação e destruição da natureza. Além disso, percebe-se o aumento da individualização da segurança reforçada pela ampliação das liberdades dos direitos e deveres que baseiam essa sociedade.

Ainda que o artigo questione as perspectivas que propõe o adestramento das pessoas cerca da problemática ambiental, o artigo não esclarece o que vem a ser de fato uma educação ambiental crítica.

Em "Imagens e interpretações em educação ambiental" a autora inicia o texto afirmando que uma das principais referências para a educação ambiental na perspectiva crítica, o Tratado de educação ambiental para sociedades sustentáveis e responsabilidade global propõe na diretriz $n^{\circ} 15$ do plano de ação garantir que os meios de comunicação se transformem em instrumentos educacionais para a preservação de recursos naturais. 
De acordo com Silva (2008) o artigo $3^{\circ}$ da Política Nacional de Educação Ambiental - Lei n 9795/ 99 dispõe que "como parte de um processo educativo mais amplo, todos tem direito à educação ambiental, incumbindo aos meios de comunicação de massa, colaborar de maneira ativa e permanente na disseminação de informações e práticas educativas sobre o meio ambiente.

Entretanto a autora destaca que há uma fragilidade nas mensagens que tratam da questão ambiental, uma vez que as mesmas priorizam a espetacularização e o catatrofismo com superficialidade das informações. Destaca que os meios de comunicação de massa têm importante papel na produção e disseminação de informações, o que inclui a questão ambiental.

Aponta que depois de fevereiro de 2007, após o relatório do painel intergovernamental de mudanças climáticas IPCC, a questão ambiental ganhou destaque nos meios de comunicação.

Sendo assim, a autora passou a adquirir revistas que abordavam a questão ambiental, principalmente as que traziam destaque na capa da revista. Seu objetivo era compreender como essa questão estava sendo tratada pela mídia. Sendo assim, escolheu as revistas Veja e Época por sua grande circulação.

Sua proposta pedagógica e de pesquisa, está ancorada na perspectiva crítica da Educação Ambiental. A autora também critica a concepção que crê em verdades universais, embora isso ainda não tenha aparecido claramente no texto.Sendo assim a autora busca responder a seguinte pergunta:

(...) que imagens a mídia impressa tem produzido para chamar atenção para o conteúdo de suas páginas voltado à questão ambiental e de que forma a análise dessas imagens poderia ser usada para a formação docente na perspectiva da educação ambiental crítica? (SILVA, 2013 p.3)

Nesse sentido, os principais objetivos do seu trabalho consistiram em identificar as concepções da questão ambiental nas imagens das capas de revista de grande circulação. Consistiu também em verificar de que forma os professores em formação interpretam, ressignificam e se apropriam das mensagens transmitidas pelas imagens. Além disso, o trabalho buscou verificar as possibilidades das imagens cotidianas serem utilizadas como objetos de reflexão dialógica e crítica na formação ambiental de professores em um processo de pesquisa-ação qualitativa.

No que se refere aos procedimentos metodológicos, a autora utiliza a análise de conteúdo proposta por Bardin (1977), a mesma utilizada neste trabalho. 
Em sua análise percebeu que há um predomínio da perspectiva pragmática e conservadora. Identificou também a perspectiva antropocêntrica, que se manifesta de uma forma onde o homem se vê como salvador da natureza. Percebeu que há o incentivo ao consumo, ainda que de produtos verdes. Nesse sentido, os autores se posicionam de maneira claramente crítica, uma vez que são contra ao atual modelo que incentiva o consumismo, ainda que de produtos considerados ecologicamente corretos.

Em apenas uma das revistas, a autora identificou uma concepção crítica da educação ambiental.

"A educação ambiental frente às mudanças climáticas globaiscontribuições da análise crítica da mídia". Neste trabalho a autora inicia seu artigo afirmando que a educação ambiental brasileira vem crescendo como área de ensino e pesquisa. Destaca que o diálogo entre o campo ambiental e o campo educacional, situa-se numa esfera interdisciplinar. Destaca também que o problema das mudanças climáticas globais ganhou espaço na mídia e na sociedade sobretudo a partir da publicação em 2007 do relatório do Painel Intergovernamental de Mudanças Climáticas - IPCC.

A pesquisa busca identificar como a mídia veicula o conhecimento científico e ambiental na sociedade e como os materiais produzidos pela mídia podem ser utilizados no contexto de formação de professores e alunos da educação básica. A autora apresenta uma noção do conceito de mudanças climáticas destacando o Painel Intergovernamental de Mudanças Climáticas o (IPCC) enquanto marco para tal discussão.

Afirma que a análise dos discursos sobre os processos comunicativos em relação às questões ambientais deve ser um dos objetivos da pesquisa em educação ambiental. Sobre a educação ambiental crítica a autora destaca que:

Na proposta de uma educação ambiental crítica, a preocupação com as dimensões éticas e políticas são essenciais. A mudança de comportamentos individuais é substituída pela construção de uma cultura cidadã na formação de atitudes ecológicas, que supõe a formação de um sentido de responsabilidade ética e social. (SILVA, 2013 p.14)

O texto apresenta aspectos de uma educação ambiental crítica, uma vez que não crê na mudança de comportamentos individuais, o que demonstra um olhar problematizador. Entretanto, como limite do artigo, podemos notar que não fica clara a concepção do que é de fato uma educação ambiental crítica. 
Em "Fundamentos da educação ambiental libertária" Barchi (2007) se apropria do conceito de Ecosofia. Destaca que na proposta ecosófica, os indivíduos tendem e devem se tornar ao mesmo tempo solidários e mais diferentes. No artigo o autor busca dar ênfase nas possibilidades de intercambio entre a educação ambiental e a educação libertária, partindo do pressuposto "ecosófico". O autor faz essa escolha por acreditar na seguinte perspectiva destacada no fragmento abaixo:

Ambas são: potencializadoras de singularidades, já que buscam frequentemente a diferenciação como prática de resistência e tomada de decisões: por ser desenvolvidas em redes de saberes, supondo que à construção de conhecimento sempre se dá de forma coletiva, e que envolvem o conceito de risco, por supor subversão e desconstrução de conceitos e representações. (BARCHI, 2007 p. 3)

Nesse sentido, sua proposta consiste na construção de um conhecimento rizomático, onde haja o diálogo entre as diversas áreas do conhecimento. Essa perspectiva adotada pelo autor se insere na categoria de epistemologia ambiental e ambiente científico transdiciplinar desenvolvidas a partir da construção do pensamento de Leff.

Ainda nesse sentido o autor destaca que o que interessa são as conexões entre os diversos saberes, o intercâmbio entre as diferentes áreas do conhecimento, além de identificar as inúmeras representações sociais. Deve-se criar diálogos entre as diferentes áreas e a partir daí, manter a possibilidade delas estarem sempre em construção através da dialogicidade, resistindo à concepções totalizantes a respeito dos diversos temas da educação ambiental. Afirma que os libertários e os ecologistas radicais buscam outras culturas escolares e sugere que os referenciais teóricos hegemônicos devem ser repensados.

Concluindo o pensamento do autor, acho interessante destacar um fragmento do seu artigo onde o mesmo afirma o seguinte: "A proposta dos/ das ecologistas e dos libertários, a partir do que já vimos aqui, em relação à educação, é, no mínimo, assumir resistir e subverter uma ordem autoritária e opressiva”. (BARCHI, 2007 p.13)

Em "Educação socioambiental de jovens e adultos: uma proposta críticoemancipatória - presencial e a distância - de formação de professores" o trabalho teve por objetivo analisar a formação de professores no que tange à abordagem temática ambiental na modalidade de ensino educação de jovens e adultos. Ainda no início do texto, é possível identificar a perspectiva crítica da autora, uma vez 
que a mesma afirma que o pensamento neoliberal é responsável pela atual crise. Seu trabalho destaca a matriz de equidade, que segundo o texto pode ser compreendido a partir da citação abaixo:

A matriz equidade enfatiza as relações entre desigualdade social e degradação ambiental, como sendo intrínsecas, preocupando-se com a erradicação da miséria e com a proteção ambiental. Relacionada ao paradigma marxista que analisa o trabalho como sendo uma mercadoria que enriquece apenas um grupo social e aliena o homem de si mesmo, pode ser considerada como síntese das matrizes de auto-suficiência e da eficiência, ao pregar a volta ao passado, no sentido de retorno aos valores, simultaneamente ao reconhecimento da importância da tecnologia em sua preocupação co a degradação ambiental, miséria e justiça social, objetivando a transformação da realidade. Tem como princípio a justiça social, a partir da superação das desigualdades, cuja construção deve ser democrática, ancorada na atuação dinâmica dos vários atores sociais. (FERREIRA, 2008 p. 5)

Sobre a pesquisa, a autora destaca que o programa foi implementado em uma escola da Baixada Fluminense, situada no município de Caxias. O programa denominado PESoA desenvolveu atividades dirigidas à docentes da EJA.

Segundo Ferreira (2007), o programa se traduz em uma proposta crítica de formação de professores em educação ambiental. Apoiada em Paulo Freire, a mesma destaca que a educação ambiental somente será verdadeira e transformadora se for fruto da própria comunidade e do reconhecimento dos saberes de seus sujeitos. Portanto, todo e qualquer educador, principalmente o ambiental, deve fazer com que sua ação seja uma resposta às diferentes necessidades colocadas pela realidade educacional e social.

$\mathrm{O}$ artigo termina com a autora concluindo que apesar das dificuldades encontradas, o programa foi relevante e tem potencial para se inserir em um programa de formação continuada de professores. No que se refere às dificuldades encontradas na implementação dessas práticas a autora afirma o seguinte:

Uma das razões para que a prática do educador que atua na EJA se distancie do caráter crítico-emancipatório, talvez seja a necessidade, não atendida que qualquer profissional tem de, em seu espaço de trabalho, refletir sobre seu fazer, ter momentos intensos de troca orientados por uma equipe pedagógica afinada com uma proposta de formação continuada, que perceba que a aproximação teoriaprática materializa as dificuldades e que há necessidade de clarificá-las para encontrar coletivamente possibilidades de atuação efetiva, relacionadas com a realidade, assumida a perspectiva de que a teoria, grande parte das vezes, reflete uma prática vivenciada. (FERREIRA, 2008 p.13)

Por último a autora destaca que a formação do sujeito crítico é tarefa da educação transformadora, emancipatória. Todos devem se ver como agentes críticos do processo de conhecer. 
"Entre a dupla determinação de homem e a revolução técnico-científica no campo da educação ambiental crítica" Soares (2009) destaca que o período atual de globalização neoliberal, difere dos outros períodos que o antecederam pela especificidade do desafio ambiental que o acompanha e que também o constitui. Destaca que até o final do século XX, a dominação da natureza não era uma questão e, sim uma solução, o desenvolvimento.

Já não é mais contra a natureza que devemos lutar, mas sim, contra os efeitos da própria intervenção da sociedade através do sistema técnico-científico. Nesse sentido a autora apresenta as transformações na relação do homem com o seu espaço. Como referência utiliza o autor Ruy Moreira que afirma a existência de 9 espaços. Não apresentarei aqui a constituição de cada espaço, uma vez que este não é o objetivo da presente análise.

No que se refere à educação escolar, Soares (2009) destaca que este é um processo no qual o professor e seu aluno se relacionam com o mundo através das relações que travam entre si na escola e nas idéias. Na mesma direção, a autora vai dizer que a educação ambiental tem o mesmo fim, que consiste em compreender e construir o mundo a partir das idéias que forma dele. Nesse caso, tanto a educação escolar quanto a educação ambiental devem estar implicadas na tarefa de fazer com que se desenvolva uma leitura do mundo. Nessa direção Soares (2009) se faz a seguinte pergunta:

Em que medida a escola e a educação ambiental necessitam se unir e se juntar na tarefa de compreender o mundo como nosso mundo se estão apartadas nos seus fazeres, o fato de sermos humanamente naturais do fato de sermos naturalmente humanos? (SOARES, 2009 p. 3)

Para responder a pergunta, a autora busca compreender a história dos espaços, uma vez que cada espaço é impregnado por seus conteúdos técnicos, ou seja, cada espaço materializa uma era técnica, sendo a técnica a encarnação da intencionalidade que preside sua função de organizar a relação ambiental do homem.

Pelo que foi possível notar, o objetivo do texto consiste em apresentar o entendimento de que a relação homem com a natureza está diretamente relaciona ao desenvolvimento das técnicas. E para que se possa compreender como as técnicas são construídas, é imprescindível entender a produção dos diferentes espaços nos seus diversos tempos históricos. Para a autora o momento atual se apresenta de uma forma onde a natureza é concebida enquanto mero recurso a ser 
transformado em riqueza. Esse pensamento fica claro a partir do que diz o fragmento abaixo:

A natureza antes mitificada torna-se dessacralizada e passa a ser percebida como um mero recurso a ser transformado em riqueza, dentro de uma lógica utilitarista desenvolvida com a revolução técnico-científica, e, posteriormente com a revolução industrial, ambas integradas à expansão do capitalismo. Este vai, pouco a pouco, transformando-se de modo de produção em verdadeiro modelo civilizatório, incluindo dimensões que ultrapassam, em muito, o econômico; isto é, como uma extraordinária síntese de pressupostos e dos valores básicos da sociedade liberalmoderna no que diz respeito ao ser humano, à natureza, à riqueza, à história, ao progresso, ao conhecimento. Esse movimento tem se dado com a intenção de integrar espaços e pessoas como produtores e consumidores, levando a todas as partes do mundo não apenas a lógica industrial, produtivista, utilitarista e consumista, mas a concepção dicotômica de relação homem/ natureza desenvolvida na modernidade ocidental. (SOARES, 2009 p. 13)

Podemos notar que embora seja crucial compreender de que o desenvolvimento técnico é responsável pela produção dos espaços o que implica dizer que concretiza a relação do homem com a natureza, está é uma discussão que já foi de certa forma superada dentro da discussão do campo da educação ambiental. Isso quer dizer que a pesar de importante e de um caráter crítico, o artigo pouco contribui na constituição de uma educação ambiental efetivamente crítica.

Em "Cidade, cotidiano, cidadania: um olhar ambiental" inicialmente Soares (2006) afirma que para o homem comum, o mundo, mundo concreto, imediato, é a cidade, sobretudo a metrópole. Para a mesma, a cidade é o espaço do movimento dos homens, movimento de co-presença. Na cidade a natureza se torna oculta, sendo apenas um produto de consumo. Como exemplo a autora mostra que a natureza é vista como uma mercadoria para ser apreciada, como no caso de florestas urbanas. Nessa direção a autora entende que a cidade é um objeto de transformações para a realização das atividades modernas de produção e de circulação, o que implica na problemática ambiental urbana.

Seu propósito consiste em pensar sobre os espaços urbanos que têm sido vistos do ponto de vista ambiental enquanto espaços mortos. Com relação ao GT 22 Educação Ambiental da ANPED, Soares (2006) afirma que no momento da sua investigação existia um total de 37 textos e 05 pôsteres e em todos eles o desafio das metamorfoses urbanas estavam ausentes. Dessa forma seu trabalho objetiva pensar o GT Educação Ambiental da ANPED relacionando e articulando 
as quatro idéias - força, ou seja, a cidade, o cotidiano, a cidadania sob um olhar ambiental, para que a cidade seja um lugar de cidadãos.

Na sua percepção, há dois níveis de territórios no concreto da cidade: as áreas chamadas de luminosas e as áreas denominadas opacas, lugar onde vivem os pobres. Pelo que se pode compreender a autora demonstra como a partir da modernização a cidade foi se transformando. Se no passado o tempo era regulado pelos homens em sua relação com a natureza, hoje o tempo é regulado pelo relógio do cartão de ponto. O dia-a-dia dos homens era marcado pela irracionalidade, pelo culto aos deuses e à natureza, o que conferia a cada povo uma explicação e entendimento do mundo de maneira diferenciada, segundo a autora.

A autora crê que o cotidiano é marcado pelo racionalismo que desfaz o mito da natureza e da magia e cria um novo mito, o da cientificidade. Nessa direção o artigo apresenta as transformações sofridas na cidade a partir da modernização. São apresentadas a evolução do conceito de cotidiano. Destaca ainda que na atualidade a palavra cidadania perdeu seu verdadeiro significado, sendo hoje reconhecidos como cidadãos, aqueles que possuem propriedade. Os homens pobres, lentos, vivem nas áreas opacas sendo obrigados a morar em beira de rios, encostas, etc. Já os homens que vivem nas áreas luminosas são os que possuem propriedade, sendo nesse caso cidadãos.

Por último a autora mostra que um olhar ambiental sobre o cotidiano citadino impõe-se, como desafio de cidadania na elucidação das metamorfoses da sociedade contemporânea e das contradições sociais urbanas, não somente para interpretá-las, mas fundamentalmente para transformá-las.

No artigo intitulado "Entre as duas revoluções industriais mecânicas e a revolução bioengenharial no campo da educação ambiental crítica" Soares (2010) afirma que uma das idéias mais poderosas do iluminismo, era que as condições naturais e sociais poderiam melhorar com a aplicação da razão e da ciência. Nesse sentido, o iluminismo serviu como marco da modernidade.

A modernização tem sua base concreta na modernidade e têm como conceito gêmeo o progresso. Assim como em outros textos, Soares (2010) utiliza a técnica para compreender e explicar a relação do homem com a natureza. Para elucidar melhor essa idéia, apresento o fragmento abaixo: 
Pode-se afirmar, também, que o instrumento mais evidente da modernização e, mais, recentemente, do desenvolvimento tem sido a técnica, um conjunto de elementos naturais e imateriais que marcam a dinâmica da sociedade como elemento fundamental nas relações entre a dinâmica da sociedade e da natureza. (SOARES, 2010 p.1)

Soares (2010) utiliza autores que acreditam que a modernidade transformou a natureza em recurso e a mesma é vista como fonte de riqueza dentro de uma visão utilitarista. Esse mesmo pensamento é o responsável pela relação dicotômica da dinâmica homem/ natureza. Nesse sentido a autora diz que:

O que tem predominado, nos últimos séculos é, de um lado, a visão de ciência como técnica e, de outro, a natureza percebida como realidade na qual o homem pode intervir em seu proveito. Em consequiência, o homem tem sido visto como produtor, criador, transformador; a natureza, como domínio a ser conquistado, explorado, submetido ao ritmo da produção econômica, a cada vez mais, em escala industrial. (SOARES, 2009 p.2)

Defende que essa racionalidade que emerge a partir do projeto iluminista, tem que ser questionada. Para a autora, uma das formas de questionarmos é a conscientização de que vivemos numa tecnosfera (conceito desenvolvido por Milton Santos). Na tecnosfera tomamos como a segunda natureza, pensamento que materializa tudo e nos faz acreditar que tudo o que nos rodeia, deve-se à revolução técnico-científica, ou como a autora chama, de revolução científico tecnológica.

Soares (2010) faz uma crítica à racionalidade técnica, à concepção dicotômica de homem e natureza, à fragmentação cartesiana e se respalda na perspectiva da dialética da natureza. Para a autora, a técnica e o formato espacial existentes hoje, são o resultado de duas revoluções industriais mecânicas, cuja ultrapassagem está a caminho com a terceira revolução industrial - a revolução bioengenharial.

Sobre as revoluções mecânicas, a autora descreve o desenrolar da primeira revolução industrial ocorrida na Inglaterra no século XVIII. Aponta o relógio como o controlador do tempo dos artesãos no seu controle na cadeia produtiva. Destaca que a segunda revolução industrial inaugura a fase do capitalismo avançado. Destaca também as transformações em relação às matérias-primas utilizadas e afirma que esse modelo atrelado à metalurgia, na petroquímica e nas energias fósseis, leva a um esgotamento rápido de alguns recursos renováveis e não renováveis. 
Sobre a revolução bioengenharial, Soares (2010) destaca que a terceira revolução industrial é a fase do capitalismo globalizado. A mesma tem início no século XX com base na microeletrônica, desdobrando-se na informática, na robótica e na engenharia genética (biotecnologia moderna). Nesse sentido a autora nos diz que a engenharia genética é o cerne da nova base material.

No que tange a nova relação técnica com a natureza e a educação ambiental, Soares aponta que estamos inseridos num momento histórico onde a cultura técnico-científica tem que ser novo o suficiente para restabelecer o capitalismo esgotado pelo velho paradigma. Afirma que é a biologia que introduz uma nova forma de compreender a natureza.

Soares (2010) conclui seu texto afirmando que a educação ambiental está desafiada a mudar a lógica de sua construção do conhecimento. Destaca que o atual período da globalização neoliberal difere dos outros períodos que o antecederam pela especificidade do desafio ambiental que o acompanham e que também, o constitui, discurso que a autora apresenta em outro dos seus artigos que já foram aqui analisados. Completa sua idéia destacando que:

Já não é mais contra a natureza que devemos lutar, mas, sim contra os efeitos da própria intervenção da sociedade humana no planeta, particularmente das intervenções do novo sistema técnico-científico, onde a noção de diversidade da natureza, a biodiversidade e a biotecnologia são as pontas de uma nova ordem paradigmática. (SOARES, 2009 p.11)

Afirma ainda que a educação ambiental deve ser concebida como educação crítica, logo "transformadora, envolvendo uma visão ampla do mundo, a clareza do ato educativo, uma posição política e uma competência técnica porque se refere à vida, a história do homem e da natureza, bem como a si mesmo". (SOARES, 2009 p.12).

No que se refere à atividade docente, a autora destaca que a atividade docente, numa visão emancipadora, deve construir comunidades de aprendizagem, desenvolver capacidade para reflexibilidade, inovação, flexibilização e combater problemas criados pela sociedade capitalista, tais como "o consumo excessivo, a perda da noção de comunidade e o distanciamento crescente entre as classes sociais, superando a distância entre teorias e ideias e práticas cotidianas". (SOARES, 2009 p.12)

Em "Educação e Meio Ambiente: As possibilidades de uma utopia vermelha e verde", o artigo desenvolve um debate no campo da Educação Ambiental. O 
autor trabalha com a formação de professores, principalmente com estudantes do curso de Pedagogia, estabelecendo relações entre meio ambiente e educação a fim de investigar os limites e possibilidades de um trabalho pedagógico a partir de escolas. Nesse sentido, o autor busca trabalhar com os alunos uma perspectiva crítica de educação ambiental articulando saberes econômicos, políticos, sociais, culturais e ecológicos.

Barreto (2010) afirma que o campo ambientalista busca superar as dicotomias direita/ esquerda, entretanto, o mesmo afirma que essa polarização ainda corresponde à atualidade o que faz com que a mesma seja discutida. Apoiado nas noções de Emir Saber, o autor vai dizer que pertencem à esquerda aqueles que se opõe ao capital. Aqueles interessados na distribuição da renda. $\mathrm{O}$ autor assinala a distância teórica entre o marxismo e o ambientalismo que ainda não foi superada, ainda que a noção de sustentabilidade não fosse estranha ao pensamento marxista. Barreto (2010) mostra que houve um abandono do caráter utópico e revolucionário do movimento socialista.

Essa crise, abandono do caráter utópico do socialismo, gerou a subestimação das contradições entre capital e trabalho. Isso se aprofunda ainda mais na medida em que o neoliberalismo avança em relação ao campo ambientalista.

$\mathrm{O}$ autor discute a insustentabilidade do projeto civilizatório apoiado no sistema capitalista, sendo importante nesse sentido discutir essas clivagens. O autor destaca que alguns ambientalistas ainda que de esquerda que são parcialmente críticos à lógica capitalista, parecem acreditar na possibilidade de um desenvolvimento sustentável. Nesse sentido, concordamos com o autor, e percebemos o seu caráter crítico, uma vez que o termo "desenvolvimento" na sua essência é totalmente incompatível com uma perspectiva sustentável.

Desse modo, o que o autor chama atenção é para a necessidade de discutir a utopia verde e vermelha, de forma a construir educadores críticos e não resignados à lógica capitalista, sendo essa predatória em sua essência. 
Tabela 3 - Artigos classificados segundo as categorias de análise

\begin{tabular}{|c|c|c|c|c|c|c|}
\hline Artigo & $\begin{array}{l}\text { Educação } \\
\text { ambiental }\end{array}$ & $\begin{array}{c}\text { Educação } \\
\text { ambiental } \\
\text { crítica }\end{array}$ & Reciclagem & $\begin{array}{l}\text { Epistemo- } \\
\text { logia } \\
\text { ambiental }\end{array}$ & $\begin{array}{l}\text { Racionalida } \\
\text { de ambiental }\end{array}$ & $\begin{array}{c}\text { O } \\
\text { conceito } \\
\text { de } \\
\text { natureza }\end{array}$ \\
\hline $\begin{array}{l}\text { Discutindo } \\
\text { a práxis } \\
\text { participativ } \\
\text { a: } \\
\text { concepções } \\
\text { e contribuiçõ } \\
\text { es à } \\
\text { educação } \\
\text { ambiental } \\
\text { crítica da } \\
\text { baixada } \\
\text { fluminense }\end{array}$ & $\begin{array}{l}\text { Concebe a } \\
\text { educação } \\
\text { ambiental } \\
\text { enquanto } \\
\text { processo } \\
\text { emancipatóri } \\
\text { o }\end{array}$ & $\begin{array}{l}\text { Educação que } \\
\text { incorpora os } \\
\text { sujeitos } \\
\text { sociais } \\
\text { permite } \\
\text { estabelecer } \\
\text { uma prática } \\
\text { pedagógica } \\
\text { contextualiza } \\
\text { da e crítica no } \\
\text { seu sentido } \\
\text { amplo } \\
\text { (crítica, } \\
\text { emancipatória } \\
\text { e } \\
\text { transformador } \\
\text { a) }\end{array}$ & Não discute & $\begin{array}{l}\text { Adota um } \\
\text { pensamento } \\
\text { complexo } \\
\text { acerca da } \\
\text { questão } \\
\text { ambiental }\end{array}$ & $\begin{array}{l}\text { Concebe a } \\
\text { enquanto não } \\
\text { neutra, nem } \\
\text { alheia aos } \\
\text { interesses } \\
\text { econômicos e } \\
\text { sociais. Critica o } \\
\text { modelo de } \\
\text { produção } \\
\text { capitalista, além } \\
\text { das dicotomias } \\
\text { sociedade/ } \\
\text { natureza, } \\
\text { capital/ trabalho }\end{array}$ & $\begin{array}{l}\text { Não } \\
\text { discute. } \\
\text { Entretanto } \\
\text { critica o } \\
\text { modelo } \\
\text { que } \\
\text { fortalece a } \\
\text { dicotomia } \\
\text { sociedade/ } \\
\text { natureza }\end{array}$ \\
\hline $\begin{array}{l}\text { Ações } \\
\text { socioambie } \\
\text { ntais em } \\
\text { uma } \\
\text { comunidade } \\
\text { cooperada: } \\
\text { trabalho e } \\
\text { conflito } \\
\text { como } \\
\text { categorias } \\
\text { centrais na } \\
\text { práxis. }\end{array}$ & $\begin{array}{l}\text { Adota uma } \\
\text { postura } \\
\text { crítica de } \\
\text { educação } \\
\text { ambiental, } \\
\text { uma vez que } \\
\text { busca } \\
\text { problematizar } \\
\text { o “óbvio" } \\
\text { apreendendo } \\
\text { diálogos, } \\
\text { experiências } \\
\text { buscando um } \\
\text { ideal } \\
\text { emancipatóri }\end{array}$ & $\begin{array}{l}\text { Crítica. } \\
\text { Utiliza como } \\
\text { referencial } \\
\text { teórico } \\
\text { metodológico } \\
\text { o pensamento } \\
\text { histórico- } \\
\text { dialético. }\end{array}$ & $\begin{array}{l}\text { Se apresenta de } \\
\text { maneira crítica, } \\
\text { uma vez que os } \\
\text { sujeitos } \\
\text { envolvidos } \\
\text { nesse processo } \\
\text { são dotados de } \\
\text { uma } \\
\text { consciência que } \\
\text { os permite } \\
\text { refletir acerca } \\
\text { da reciclagem. }\end{array}$ & Não aborda & $\begin{array}{l}\text { Crítica. } \\
\text { Problematiza a } \\
\text { relação homem } \\
\text { versus natureza. }\end{array}$ & $\begin{array}{l}\text { Crítica. } \\
\text { Critica a } \\
\text { relação que } \\
\text { desconside } \\
\text { ra as } \\
\text { relações } \\
\text { homem } \\
\text { versus } \\
\text { natureza. }\end{array}$ \\
\hline
\end{tabular}




\begin{tabular}{|c|c|c|c|c|c|c|}
\hline & o. & & & & & \\
\hline $\begin{array}{l}\text { Caminhos } \\
\text { para a a } \\
\text { inserção } \\
\text { socioambie } \\
\text { ntal: } \\
\text { possibilidad } \\
\text { es e } \\
\text { obstáculos } \\
\text { encontrados } \\
\text {. }\end{array}$ & 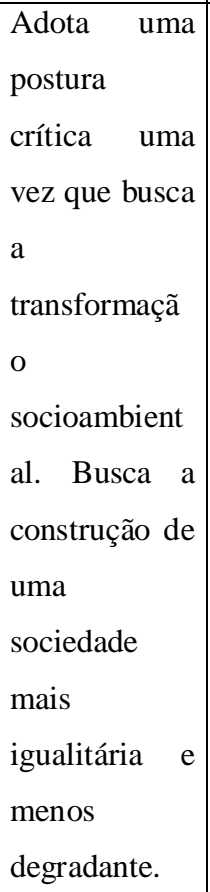 & 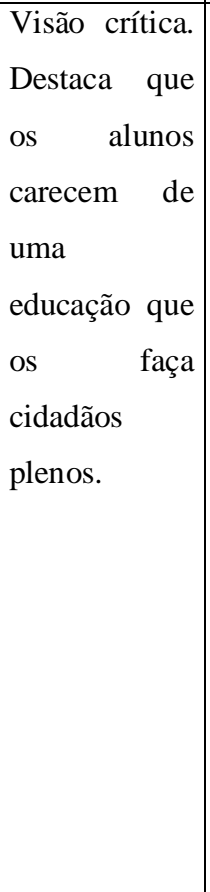 & $\begin{array}{lr}\text { Não aborda. } \\
\text { Entretanto, a } \\
\text { autora } & \text { se } \\
\text { posiciona } & \text { de } \\
\text { forma contrária } \\
\text { ao atual } \\
\text { modelo de } \\
\text { produção que } \\
\text { estimula } \\
\text { consumismo } \\
\text { desenfreado. }\end{array}$ & $\begin{array}{l}\text { Crítica. Rejeita } \\
\text { as verdades } \\
\text { universais. }\end{array}$ & $\begin{array}{l}\text { Considera que a } \\
\text { crise } \\
\text { socioambiental } \\
\text { origina-se de } \\
\text { uma visão } \\
\text { antropocêntrica } \\
\text { e utilitarista de } \\
\text { natureza. }\end{array}$ & $\begin{array}{l}\text { Considera } \\
\text { que a crise } \\
\text { socioambie } \\
\text { ntal } \\
\text { origina-se } \\
\text { de uma } \\
\text { visão } \\
\text { antropocên } \\
\text { trica e } \\
\text { utilitarista } \\
\text { da } \\
\text { natureza. }\end{array}$ \\
\hline $\begin{array}{l}\text { Formação } \\
\text { de redes: } \\
\text { uma } \\
\text { dimensão } \\
\text { pedagógica } \\
\text { para a } \\
\text { sustentabili } \\
\text { dade }\end{array}$ & $\begin{array}{l}\text { Se } \\
\text { de }\end{array}$ & 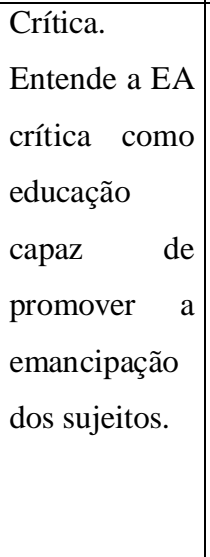 & Não aborda. & $\begin{array}{l}\text { Crítica. Propõe } \\
\text { a ação } \\
\text { dialógica. }\end{array}$ & $\begin{array}{l}\text { Crítica. Nega a } \\
\text { concepção } \\
\text { antropocêntrica } \\
\text { de natureza. }\end{array}$ & $\begin{array}{l}\text { Crítica. } \\
\text { Uma vez } \\
\text { que como } \\
\text { já foi dito, } \\
\text { a autora } \\
\text { nega a } \\
\text { visão } \\
\text { antropocên } \\
\text { trica de } \\
\text { natureza. }\end{array}$ \\
\hline $\begin{array}{l}\text { A } \\
\text { imprescindí } \\
\text { vel adoção } \\
\text { da teoria } \\
\text { crítica na } \\
\text { formação } \\
\text { do educador } \\
\text { ambiental: } \\
\text { um caminho } \\
\text { para o } \\
\text { enfrentame } \\
\text { nto da crise } \\
\text { socioambie } \\
\text { ntal e para a } \\
\text { transformaç } \\
\text { ão da } \\
\text { relação }\end{array}$ & 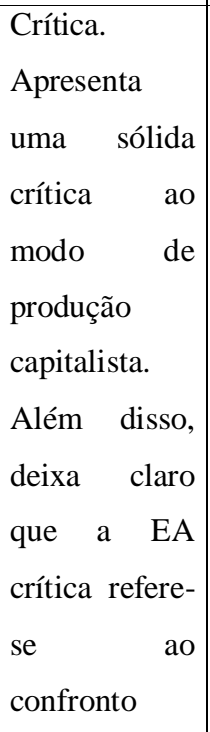 & $\begin{array}{ll}\text { Usa } \quad \text { como } \\
\text { referencial } \\
\text { teórico } & \text { o } \\
\text { marxismo. }\end{array}$ & $\begin{array}{l}\text { Faz uma crítica } \\
\text { da reutilização } \\
\text { de materiais no } \\
\text { sentido } \\
\text { individualizado } \\
\text {. }\end{array}$ & $\begin{array}{|lr|}\text { Crítica, } & \\
\text { embora } & \text { não } \\
\text { desenvolva } & \text { de } \\
\text { maneira } & \text { clara, } \\
\text { tal } & \text { como } \\
\text { concebemos } \\
\text { esta } & \text { categoria } \\
\text { de análise. }\end{array}$ & $\begin{array}{l}\text { Crítica. Embora } \\
\text { não desenvolva } \\
\text { de forma clara } \\
\text { essa categoria. }\end{array}$ & $\begin{array}{l}\text { Não } \\
\text { problemati } \\
\text { za o } \\
\text { conceito de } \\
\text { natureza. } \\
\text { Entretanto } \\
\text { podemos } \\
\text { afirmar } \\
\text { que sua } \\
\text { concepção } \\
\text { é crítica, } \\
\text { uma vez } \\
\text { que seu }\end{array}$ \\
\hline
\end{tabular}




\begin{tabular}{|c|c|c|c|c|c|c|}
\hline $\begin{array}{l}\text { desigual } \\
\text { homem- } \\
\text { sociedade- } \\
\text { natureza. }\end{array}$ & $\begin{array}{l}\text { com o padrão } \\
\text { societário } \\
\text { vigente. }\end{array}$ & & & & & $\begin{array}{l}\text { estudo se } \\
\text { apóia no } \\
\text { materialis } \\
\text { mo } \\
\text { histórico } \\
\text { dialético. }\end{array}$ \\
\hline $\begin{array}{l}\text { O trabalho } \\
\text { cooperativo } \\
\text { no } \\
\text { enfrentame } \\
\text { nto dos } \\
\text { limites que } \\
\text { o tempo } \\
\text { hegemônico } \\
\text { impõe à } \\
\text { prática de } \\
\text { uma educação } \\
\text { educa } \\
\text { ambiental } \\
\text { emancipatór } \\
\text { ia. }\end{array}$ & $\begin{array}{l}\text { Crítica. Faz a } \\
\text { devida crítica } \\
\text { ao } \\
\text { capitalismo } \\
\text { mundializado } \\
\text { Busca } \\
\text { estratégias } \\
\text { que sejam } \\
\text { emancipatória } \\
\text { s. }\end{array}$ & $\begin{array}{l}\text { Crítico. } \\
\text { Apoia-se no } \\
\text { materialismo } \\
\text { histórico } \\
\text { dialético. }\end{array}$ & $\begin{array}{l}\text { Não aborda de } \\
\text { forma direta. } \\
\text { Ainda assim, } \\
\text { nota-se o } \\
\text { caráter crítico } \\
\text { do artigo em } \\
\text { relação a esta } \\
\text { categoria, uma } \\
\text { vez que os } \\
\text { autores } \\
\text { criticam a } \\
\text { lógica } \\
\text { sociedade } \\
\text { individualista, } \\
\text { consumista, } \\
\text { mercantilizada } \\
\text { e excludente. }\end{array}$ & $\begin{array}{l}\text { Não aborda } \\
\text { diretamente. }\end{array}$ & $\begin{array}{l}\text { Crítico. Nega a } \\
\text { concepção } \\
\text { antropocêntrica. }\end{array}$ & Crítico. \\
\hline $\begin{array}{l}\text { Da } \\
\text { evolução da } \\
\text { concepção } \\
\text { de natureza } \\
\text { e de homem } \\
\text { na } \\
\text { ambivalênci } \\
\text { a de uma } \\
\text { educação } \\
\text { ambiental } \\
\text { crítica. }\end{array}$ & $\begin{array}{l}\text { Crítico. } \\
\text { Critica o } \\
\text { capitalismo. }\end{array}$ & Crítico. & Não aborda. & $\begin{array}{l}\text { Crítico }-\mathrm{Se} \\
\text { apresenta de } \\
\text { forma } \\
\text { contrária ao } \\
\text { pensamento } \\
\text { único. }\end{array}$ & Crítico. & $\begin{array}{l}\text { Crítico - } \\
\text { destaca os } \\
\text { prejuízos } \\
\text { da } \\
\text { dicotomia } \\
\text { homem - } \\
\text { natureza. }\end{array}$ \\
\hline $\begin{array}{l}\text { Uma } \\
\text { aproximaçã } \\
\text { o entre } \\
\text { Gadamer e } \\
\text { Paulo Freire } \\
\text { como } \\
\text { contribuiçã } \\
\text { o para } \\
\text { refletir } \\
\text { sobre a } \\
\text { pesquisa em }\end{array}$ & Crítica & $\begin{array}{l}\text { Crítica, uma } \\
\text { vez que se } \\
\text { apóia em } \\
\text { Paulo Freire e } \\
\text { acredita que } \\
\text { deve haver a } \\
\text { superação das } \\
\text { racionalidade } \\
\text { s dominantes }\end{array}$ & Não aborda & $\begin{array}{l}\text { Crítico - Uma } \\
\text { vez que se } \\
\text { apresenta de } \\
\text { maneira } \\
\text { contrária ao } \\
\text { pensamento } \\
\text { único }\end{array}$ & \begin{tabular}{|lr}
\multicolumn{2}{|c}{ Crítico - Mostra } \\
a necessidade de \\
superação \\
homem do \\
centro romo \\
mundo
\end{tabular} & $\begin{array}{l}\text { Crítico. } \\
\text { Não } \\
\text { concorda } \\
\text { com a } \\
\text { dicotomia } \\
\text { homem - } \\
\text { natureza }\end{array}$ \\
\hline
\end{tabular}




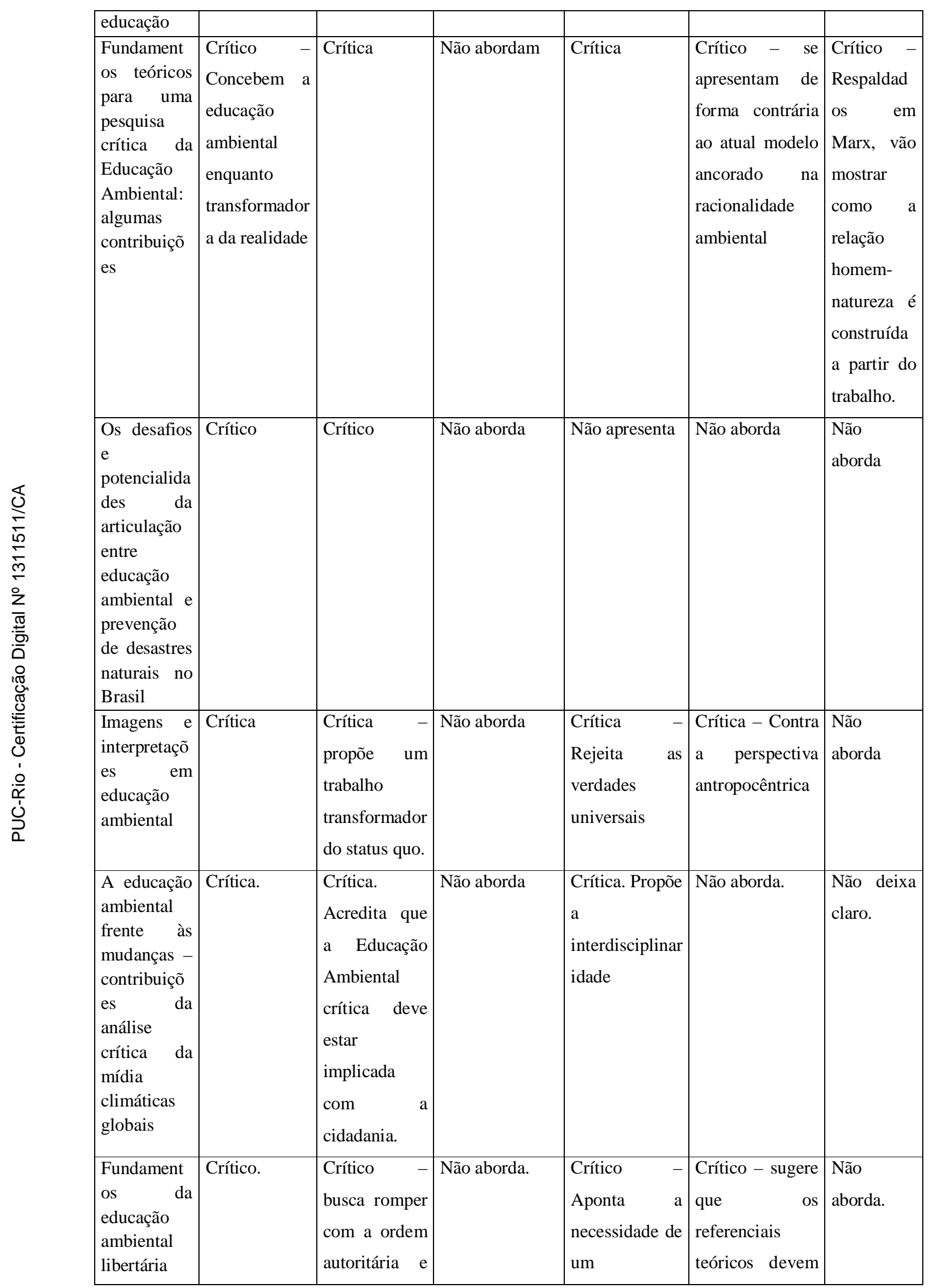




\begin{tabular}{|c|c|c|c|c|c|c|}
\hline & & opressiva. & & \begin{tabular}{|l} 
pensamento \\
rizomático \\
com o diálogo \\
entre os \\
diferentes \\
campos do \\
conhecimento.
\end{tabular} & ser repensados. & \\
\hline $\begin{array}{l}\text { Educação } \\
\text { socioambie } \\
\text { ntal de } \\
\text { jovens e } \\
\text { adultos: } \\
\text { uma } \\
\text { proposta } \\
\text { crítico- } \\
\text { emancipatór } \\
\text { ia - } \\
\text { presencial e } \\
\text { a distância } \\
-\quad r \text { de } \\
\text { formação de } \\
\text { professores }\end{array}$ & $\begin{array}{|lr|}\text { Crítico } & - \\
\text { Trabalha } & \text { a } \\
\text { matriz } & \\
\text { equidade, } & \\
\text { além } & \text { de } \\
\text { criticar } & \mathrm{o} \\
\text { modelo } & \\
\text { capitalista. } & \end{array}$ & $\begin{array}{l}\text { Crítica. } \\
\text { Propõe } \\
\text { transformaçã } \\
0 \quad \text { da } \\
\text { realidade. }\end{array}$ & Não aborda. & $\begin{array}{lr}\text { Crítica } & - \\
\text { Propõe } & \text { a } \\
\text { interdisciplinar } \\
\text { idade. }\end{array}$ & Crítico. & $\begin{array}{l}\text { Não } \\
\text { apresenta. }\end{array}$ \\
\hline $\begin{array}{l}\text { Entre a } \\
\text { dupla } \\
\text { determinaçã } \\
\text { o de homem } \\
\text { e a a } \\
\text { revolução } \\
\text { técnico- } \\
\text { científica no } \\
\text { campo da } \\
\text { educação } \\
\text { ambiental } \\
\text { crítica }\end{array}$ & $\begin{array}{l}\text { Crítica } \\
\text { Apresenta } \\
\text { uma crítica ao } \\
\text { capitalismo } \\
\text { industrial. }\end{array}$ & $\begin{array}{lr}\text { Crítica- } & \hat{E} \\
\text { contra } & \text { a } \\
\text { dicotomia } & \\
\text { homem/ } & \\
\text { natureza. } & \end{array}$ & Não aborda. & $\begin{array}{l}\text { Crítica } \\
\text { responsabiliza } \\
\text { a ciência pelos } \\
\text { problemas } \\
\text { ambientais. }\end{array}$ & Crítica. & $\begin{array}{l}\text { Crítica. } \\
\text { Parte de } \\
\text { uma } \\
\text { perspectiva } \\
\text { dialética de } \\
\text { natureza. }\end{array}$ \\
\hline $\begin{array}{l}\text { Cidade, } \\
\text { cotidiano, } \\
\text { cidadania: } \\
\text { um olhar } \\
\text { ambiental }\end{array}$ & $\begin{array}{|ll|}\text { Crítica } & - \\
\text { acredita que o } & \\
\text { olhar } & \\
\text { ambiental } & \\
\text { deve } & \\
\text { promover } & \text { a } \\
\text { cidadania. } & \\
\end{array}$ & $\begin{array}{ll}\text { Crítico } & - \\
\text { Condena } & \text { a } \\
\text { ógica } & \\
\text { consumista. } & \end{array}$ & Não aborda. & $\begin{array}{l}\text { Critica } \quad- \\
\text { Condena a } \\
\text { racionalidade } \\
\text { que emerge na } \\
\text { modernidade. }\end{array}$ & Crítica. & $\begin{array}{l}\text { Crítica. } \\
\text { Nega a } \\
\text { dicotomia } \\
\text { homem - } \\
\text { natureza. }\end{array}$ \\
\hline $\begin{array}{l}\text { Entre as } \\
\text { duas } \\
\text { revoluções } \\
\text { industriais } \\
\text { mecânicas e } \\
\text { a revolução } \\
\text { bioengenhar }\end{array}$ & Crítico. & $\begin{array}{ll}\text { Crítico } & - \\
\text { Critica } & \text { a } \\
\text { dicotomia } & \\
\text { homem/ } & \\
\text { natureza. } & \end{array}$ & Não aborda. & $\begin{array}{l}\text { Crítica - faz } \\
\text { uma crítica à } \\
\text { fragmentação } \\
\text { cartesiana. }\end{array}$ & $\begin{array}{l}\text { Crítica - critica } \\
\text { a racionalidade } \\
\text { técnica. }\end{array}$ & $\begin{array}{l}\text { Crítica - } \\
\text { Concorda } \\
\text { com a } \\
\text { perspectiva } \\
\text { da dialética }\end{array}$ \\
\hline
\end{tabular}




\begin{tabular}{|c|c|c|c|c|c|c|}
\hline $\begin{array}{ll}\text { ial } & \text { no } \\
\text { campo da } & \text { ducação } \\
\text { educal } \\
\text { ambiental } \\
\text { crítica }\end{array}$ & & & & & & $\begin{array}{l}\text { da } \\
\text { natureza. }\end{array}$ \\
\hline $\begin{array}{l}\text { Educação } \\
\text { e Meio } \\
\text { Ambiente } \\
: \quad \text { As } \\
\text { possibilid } \\
\text { ades de } \\
\text { uma } \\
\text { utopia } \\
\text { vermelha } \\
\text { e verde }\end{array}$ & Crítico. & $\begin{array}{l}\text { Crítico. } \\
\text { Apresenta um } \\
\text { dura crítica } \\
\text { ao modelo } \\
\text { societário } \\
\text { vigente. }\end{array}$ & Não aborda. & Não aborda. & Crítico. & $\begin{array}{l}\text { Não } \\
\text { desenvolve } \\
\text {. }\end{array}$ \\
\hline
\end{tabular}

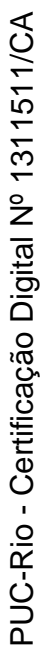




\section{4. Resultados}

Nessa parte do trabalho serão apresentados os resultados da análise desenvolvida. Embora o recorte temporal da análise seja os artigos publicados nos últimos 8 anos, período que compreende entre 2005 e 2013, os trabalhos que se julgam críticos começam a aparecer em 2007. Embora a problemática ambiental tenha ganhado destaque nas últimas décadas do século $\mathrm{XX}$, somente no início deste século os autores que tiveram seus trabalhos publicados na ANPED começaram a perceber a necessidade de um enfoque crítico no que se refere à questão ambiental. Outra coisa que chama atenção na análise dos artigos diz respeito ao referencial teórico. Dos 18 trabalhos analisados na presente dissertação, apenas 3 trabalhos utilizam Enrique Leff ${ }^{4}$ em suas referências bibliográficas. Entretanto, 14 dos artigos têm como referencia teórica a produção intelectual de Carlos Frederico Bernardo Loureiro ${ }^{5}$. Esse fato chama atenção pela grande contribuição teórica de Leff e também porque Loureiro utiliza o autor, fato que nos faz crer que os autores utilizados não estão indo nos clássicos ${ }^{6}$.

Antes de iniciar a explanação acerca dos artigos analisados, cabe ressaltar que todos foram analisados de maneira criteriosa a partir do preenchimento da tabela que contém as categorias de análise exibida mais adiante. Serão a partir dos resultados da tabela e da leitura dos artigos em sua totalidade que apresentaremos os resultados. Adverte-se ainda, que a seguir será feita uma exposição dos artigos na sua totalidade.

De maneira geral podemos dizer que os resultados foram positivos no que se refere à penetração da Educação Ambiental crítica nos artigos da ANPED. Quando utilizamos o termo positivo, estamos nos referindo a compatibilidade do caráter crítico dos artigos com o referencial teórico utilizado na presente

\footnotetext{
${ }^{4}$ Coordenador da Rede de Formação Ambiental para a América Latina e Caribe do Programa das Nações Unidas para O Meio Ambiente. É um dos principais intelectuais latino-americanos no âmbito da problemática ambiental.

5 Biólogo, mestre em Educação, doutor em Serviço Social Pela Escola de Serviço Social da Universidade Federal do Rio de Janeiro. É professor da Faculdade de Educação da mesma universidade.

${ }^{6}$ (...) um clássico é o resultado do primitivo esforço da exploração humana que goza de status privilegiado em face da exploração contemporânea no mesmo campo. (ALEXANDER, 1999. P. 24).
} 
dissertação, e não ao fato de encontrar o resultado esperado a partir da construção de uma hipótese previamente formulada.

Em sua totalidade os artigos se apresentam de forma crítica. No que se refere à categoria educação ambiental, todos os autores parecem comungar de uma perspectiva que concebe a mesma enquanto educação emancipatória, capaz de desenvolver a autonomia dos sujeitos e torná-los críticos frente ao modelo de produção capitalista.

Sobre a categoria Educação Ambiental Crítica, os autores demonstram a necessidade de romper com a lógica que constrói a dicotomia homem/ natureza, além de romper com posturas que incentivam o consumismo. De forma global foi possível perceber que os autores buscam alternativas para a lógica da ciência moderna, destacando essa perspectiva como uma das responsáveis pela degradação ambiental. Além disso, os artigos utilizam autores que trabalham numa perspectiva crítica e que em sua maioria comungam com as idéias produzidas pelo marxismo.

A categoria reciclagem foi pouco presente nos trabalhos analisados. Somente 3 artigos problematizam a questão e os mesmos se apresentam de maneira crítica. Entretanto, pode-se afirmar que muitos dos autores embora não abordem o tema (não é seu objeto de estudo), foi possível notar uma perspectiva que trabalha na lógica crítica, uma vez que responsabilizam a consumismo exacerbado pelos problemas ambientais e não os sujeitos. Também não propõem em seus trabalhos ações comportamentalistas e individualizadas para a superação dos problemas ambientais contemporâneos. Ainda assim foi possível notar que as questões levantadas em torno da reciclagem ainda se apresentam de forma tímida nos trabalhos. Obviamente que reconhecemos a importância da crítica à lógica consumista, assim como à crítica às posturas comportamentalistas e individualizadas. Nesse sentido a discussão carece de um aprofundamento reflexivo no que diz respeito à obsolescência planejada, tema que não é problematizado em nenhum dos artigos. Nesse sentido, Layrargues (2011) afirma que a questão do lixo vem sendo apontada pelos ambientalistas como um dos mais graves problemas ambientais urbanos da atualidade. Ainda assim, o autor reconhece que muitos dos programas voltados para a reciclagem nas escolas trabalham com uma concepção que se restringe à coleta seletiva do lixo em detrimento de uma reflexão mais profunda e crítica. 
No que tange à obsolescência planejada o autor nos mostra que os indivíduos são obrigados a consumir bens que se tornam obsoletos antes do tempo, uma vez que se tornam inúteis logo após saírem das fabricas. $\mathrm{Na}$ concepção de Padilha (2013) para mover esta sociedade de consumo precisamos consumir o tempo todo e desejar novos produtos para substituir os que já temos; seja por falha, por acharmos que surgiu outro exemplar mais desenvolvido tecnologicamente ou simplesmente porque saíram de moda. Podemos considerar a existência de três tipos de obsolescência, a saber: obsolescência de função, obsolescência de qualidade e obsolescência de desabilidade. O primeiro caso ocorre quando um produto perde a sua função, por meio da criação de novos produtos que desenvolvam melhor a mesma função. No segundo caso, ocorre quando um produto já é concebido com vistas a falhar. Como exemplo temos a lâmpada ${ }^{7}$. Podemos ainda falar das impressoras, que já são produzidas com vistas a imprimir um determinado número de páginas, ou mesmo secadores de cabelo, que possuem vida útil em horas de secagem. Muitos são os exemplos nesse caso, e não se trata de um processo natural, mas sim criado, até porque, se lembrarmos bem, antigamente um liquidificador durava anos. O último e terceiro caso de obsolescência consiste em produzir novos produtos, que em nossa mente já estão cansados. O exemplo clássico nesse caso são os aparelhos de telefone celular. A cada mês parecem criar telefones mais modernos, com alto desempenho, com funções de câmera, GPS, rádio, etc., e ainda que o sujeito já possua um telefone que funcione, o mesmo é levado por meio de propagandas a desejar e adquirir outro.

Indo além da obsolescência planejada podemos nos debruçar no caráter fetichista da mercadoria conforme Marx propôs. Marx destaca que o caráter místico da mercadoria não resulta de seu valor de uso. A mercadoria que deveria ser o resultado da quantidade de trabalho na produção do mesmo, passa a ser

\footnotetext{
${ }^{7}$ Trata-se da estratégia de estabelecer uma data de morte de um produto, seja por meio de mau funcionamento ou envelhecimento perante as tecnologias mais recentes. Essa estratégia foi discutida como solução para a crise de 1929. O conceito teve início por volta de 1920, quando fabricantes começaram a reduzir de propósito a vida de seus produtos para aumentar venda e lucro. A primeira vítima foi a lâmpada elétrica, com a criação do primeiro cartel mundial (Phoebus) para controlar a produção. Seus membros perceberam que lâmpadas que duravam muito não eram vantajosas. A primeira lâmpada inventada tinha durabilidade de 1.500 horas. Em 1924, as lâmpadas duravam 2.500 horas. Em 1940, o cartel atingiu seu objetivo: a vida-padrão das lâmpadas era de 1.000 horas. Para que esse objetivo fosse atingido, foi preciso fabricar uma lâmpada mais frágil. Padilha e Bonifácio (2013)
} 
"deusificada" como se a mesma não fosse resultado do trabalho humano. Tentando traçar um paralelo com os dias atuais, o que observamos é um movimento das pessoas sendo constantemente obrigadas a consumir sem se quer questionar o valor das mercadorias. A relação do ter em detrimento do ser no capitalismo transforma os cidadãos em meros consumidores. Aproveitando-se disso, empresas com o apoio midiático desfazem as relações entre trabalho e mercadoria em produções que são totalmente contrárias ao movimento ambiental.

Desrespeito com a natureza, testes em animais desenvolvidos por empresas de cosméticos são alguns dos inúmeros exemplos que poderiam ser citados aqui.

Diante do exposto anteriormente, surge à reflexão: Como subverter a lógica do consumismo? É possível ludibriar os interesses das grandes corporações que passam por cima da ética e da lógica da sustentabilidade? Nesse mesmo sentido, Boff (2012) nos diz que:

O atual modo de produção visando o mais alto nível de acumulação (como posso ganhar mais?) comporta a dominação da natureza e a exploração de todos os seus bens e serviços. Para este propósito se utilizam todas as tecnologias, desde as mais sujas, como àquelas ligadas à mineração e à extração de gás e petróleo, até as mais sutis, que utilizam a genética e a nanotecnologia. (BOFF, 2012 p.21)

Além disso, acrescentamos ainda, e o lixo? Não é novidade nenhuma dizer que o sistema de produção capitalista visa à maximização dos lucros e a minimização dos custos. Sendo assim, "os restos" do petróleo também são utilizados para essa função. O que dizer das garrafas pet? É de conhecimento de ambientalistas que a mesma demora em média 500 anos para se decompor da natureza. Mas por que então são utilizados esse material e não outro, como a garrafa de vidro retornável. Obviamente isso não acontece, pois muito dinheiro circula em função do simples lixo do petróleo. E a alternativa, qual seria? Os três "erres" propostos na Carta da Terra? Reduzir, reciclar e reutilizar? Será de fato justo e uma solução incentivar a criação de sofá desenvolvido por garrafa pet? Vasos de plantas feitos de garrafa pet, etc. Até que ponto podemos reutilizar tudo o que consumimos, ainda que seja algo imposto pela lógica do capital?

Layrargues (2011) nos adverte que a reciclagem como vem sendo feita, ou seja, desprovida de políticas públicas, tem muito pouco de ecológico, tendo se tornado na verdade uma atividade econômica como qualquer outra (o autor se refere à reciclagem de latas de alumínio). $\mathrm{O}$ autor afirma ainda que a reciclagem pode se tornar um fator de alienação, em suas palavras: 
A reciclagem pode ser o traço de união entre produção e consumo, mas é também a alienação do consumismo como fator de degradação ambiental e engrenagem dos mecanismos sociais de acumulação de capital e concentração de renda. $\mathrm{O}$ ato de reciclar, atualmente, ainda significa muito pouco em relação à melhoria ambiental, mas isso não quer dizer que a idéia da reciclagem deve ser abandonada; ao contrário, essa constatação evidencia o tamanho do desafio que há pela frente. Enfim, essas considerações também nos permitem enfatizar que o enfrentamento da questão do lixo requer medidas tanto técnicas como políticas, estas últimas essenciais para acelerar o ritmo do metabolismo industrial e para evitar a continuidade da exploração do trabalho pelo capital. (LAYRARGUES, 2011 p. 215)

No que se refere à categoria Epistemologia ambiental apenas 3 autores não deixam claro sua posição com relação a mesma. Do mais, todos os autores se apresentam de forma crítica. Dentre seus questionamentos, podemos citar a falta de diálogo entre os diferentes campos do conhecimento, uma dura crítica à ciência cartesiana e ao pensamento único. Ainda que os autores tenham apresentado uma crítica à falta de diálogo entre as diferentes áreas do conhecimento, os mesmos não problematizam a necessidade de um saber interdisciplinar (para além do simples intercâmbio entre saberes) conforme nos propõe Leff.

Sobre a racionalidade ambiental apenas 2 autores não enfatizam a questão. Os que apresentam essa categoria em seus trabalhos, fica nítida a necessidade de problematizar essa questão, ainda que a mesma aparente ser uma discussão superada.

Para além das categorias de análise, ou ainda para melhor explicitar como elas aparecem nos artigos, serão apresentadas as idéias centrais presentes nos mesmos. Dentre as críticas identificadas no que tange à construção ambiental crítica, alguns autores criticam a forma como as escolas apresentam a mesma. Afirmam que na maior parte das escolas a educação ambiental, assim como em outras áreas do saber, são trabalhadas de forma fragmentada e descontextualizada. Em um dos artigos a autora afirma que a escola é importante para a transformação social, mas as políticas que a sustentam se mantém na lógica do capital.

Outra questão bastante problematizada se refere ao caráter político acerca da questão ambiental. Muitos vão chamar atenção ao fato de que a educação ambiental muitas vezes é construída de forma despolitizada, uma vez que a política se apresenta de forma descolada da realidade social. Enfatizam também que muitos professores mantém uma percepção a-histórica da realidade onde não aparecem idéias revolucionárias nem anti-ideológicas. Talvez essa realidade esteja 
relacionada à formação de professores. Um dos artigos analisados oferece uma importante contribuição ao campo ao apresentar dados de uma pesquisa em cursos de formação de professores apontando que a educação ambiental crítica, depende obrigatoriamente de uma formação docente de qualidade. Entendendo a universidade enquanto espaço de produção de conhecimentos, torna-se necessário que os currículos das universidades contemplem a educação ambiental crítica a partir da construção de um currículo sólido que dialogue com os diferentes campos do saber.

Um dado triste e revelador apontam para a existência de currículos das faculdades de formação de professores que ainda se pautam em modelos predatórios e com soluções técnicas. Além do mais, os professores não estão sendo preparados para compreenderem e transformarem a própria realidade. Isso nos leva a perceber que os currículos ainda estão em certa medida sendo construídos de forma tradicional, seja nas escolas ou nas universidades. $O$ fragmento abaixo nos apresenta a concepção de um currículo tradicional em contraste com o crítico tal como estamos chamando aqui;

Os modelos tradicionais do currículo restringiam-se à atividade técnica de como fazer o currículo. As teorias críticas sobre o currículo, em contraste começam por colocar em questão precisamente os pressupostos dos presentes arranjos sociais e educacionais. As teorias críticas desconfiam do status quo, responsabilizando-o pelas desigualdades e injustiças sociais. Para as teorias críticas o importante não é o desenvolver técnicas de como fazer o currículo, mas desenvolver conceitos que nos permitam compreender o que o currículo faz. (SILVA, 1999 p. 30)

Ainda sobre a questão curricular um grave problema identificado por Arroyo diz respeito ao aspecto conteúdista do currículo, que muitas vezes não leva em consideração vidas tão precarizadas dos nossos educandos. Há uma disputa entre identidade educadora e identidade docente, e nesse campo de forças os professores estão sendo reduzidos a meros aulistas - nas palavras do autor.

Não é somente o papel do professor (enquanto educador ou aulista) que está em jogo, mas também o que ensinar. Se ensinamos aos sujeitos, e é na prática docente que conformamos nossas identidades, como podemos ensinar conteúdos esvaziados de experiências, ou que não levem em consideração a vida dos educandos? Que conhecimentos devem ser privilegiados na organização curricular? Os conhecimentos científicos, que conforme Santos (2010), se constitui como um modelo global, e totalitário, na medida em que nega o caráter racional a todas as formas de conhecimento que não se pautarem pelos seus 
princípios epistemológicos e pelas suas regras metodológicas ou os conhecimentos produzidos a partir das experiências dos sujeitos? Não é ético considerar apenas o conhecimento científico como o conhecimento socialmente válido para ser compartilhado. É necessário partir do real dos estudantes, valorizando outras formas de conhecimento.

Além do currículo, a sala de aula passou a ser um espaço amplamente disputado, uma vez que é no chão da escola que experiências são trocadas e os conhecimentos são produzidos. Para o autor, entender o novo contexto vivido nas salas de aula e as reações conservadoras é fundamental para tomar posições políticas de conformação de novas identidades profissionais. (Arroyo, 2013). Infelizmente como foi destacado acima o currículo ainda é construído de forma rígida sem respeitar a realidade dos sujeitos. Parece ainda ser mais importante fazer com que o aluno compreenda o clima polar do que as questões ambientais que estão presentes no seu espaço vivido, para citar um exemplo. Além disso, a educação ambiental ainda é vista de forma transversal no currículo e nem sempre acaba sendo contemplada, uma vez que os professores são pressionados a apresentarem todos os conteúdos socialmente aceitos e compartilhados. Esse processo parece ter se intensificado, sobretudo com o desenvolvimento de avaliações para medir a qualidade do ensino. Hoje, o processo avaliativo, antecede os conteúdos, o que quer dizer que o professor apresenta os mesmos de forma a contemplar a avaliação.

Outra crítica encontrada nos artigos trata da precarização do trabalho docente. Com relação à formação de professores, um dos artigos denuncia a falta de comprometimento do poder público com a Educação. Uma das pesquisas investigou a educação ambiental na Universidade do Estado do Rio de Janeiro. Na referida universidade havia um número muito grande de professores contratados com salários bem inferiores aos dos professores concursados e com a mesma titulação. Em outro artigo que investigava a educação ambiental na educação de jovens e adultos a pesquisa revelou que os professores não possuem tempo para a troca de experiências orientada nem para a reflexão. Outro entrave na realização de uma educação ambiental transformadora está relacionado à falta de programas de formação continuada.

Outra questão que se apresenta de forma latente nos trabalhos realizados, diz respeito à confusão da tendência crítica com a conservadora. Um dos trabalhos 
chega a afirmar que muitas vezes o termo crítico se apresenta como a ação pura e simples de criticar, o que acaba muitas vezes reproduzindo uma percepção ingênua, romântica, fragmentada e descontextualizada acerca da educação ambiental. Além disso, muitos professores compartilham de um pensamento que crê na possibilidade de transformação a partir de um caráter salvacionista.

Uma das questões levantadas nos artigos analisados, e que consideramos de extrema importância, diz respeito às possibilidades de realizar trabalhos de educação ambiental crítica. Como já foi discutido anteriormente, todo e qualquer ambientalista que se julgue critico deve reconhecer as origens dos problemas ambientais. Entretanto o conformismo com o atual modelo não será capaz de diminuir e/ ou eliminar o caráter destrutivo do capitalismo mundializado. Nesse sentido foi possível identificar alguns discursos resignados que busca uma educação ambiental crítica dentro das possibilidades, limites e tensionamentos de projetos políticos pedagógicos realizados em um contexto do "capitalismo mundializado". Esse pensamento sugere as seguintes perguntas: Como desenvolver trabalhos de educação ambiental crítica num contexto capitalista?Será que é de fato possível promover algum tipo de mudança? Que mudanças seriam essas e quais estratégias adotar? Transformações comportamentais seriam capazes de aniquilar as mazelas que a natureza sofre nos dias de hoje? Como concorrer com o poder do capital na minimização dos impactos ambientais? Esse trabalho não pretende responder a todas essas indagações, mas certamente se posiciona numa perspectiva que não crê que mudanças serão possíveis dentro do atual modelo capitalista de produção. Embora o artigo que apresenta esse pensamento conformista se julgue crítico, algumas contradições puderam ser identificadas. Numa perspectiva marxista esse pensamento não se sustenta promovendo profundas contradições.

Por outro lado, foi possível notar concepções que dialogam com o anarquismo, dos libertários e ecologistas radicais. Essa concepção propõe a emancipação e a mudança de paradigma (seja ele social, econômico, político, cultural ou ambiental). Propõe também um currículo anárquico/ libertário e caótico.

Um tema interessante que também apareceu durante as análises trata da questão ambiental na mídia. $\mathrm{O}$ artigo problematizava a contribuição da mídia na educação ambiental. Seu esforço consistia em verificar as possibilidades das 
imagens cotidianas serem utilizadas como objetos de reflexão crítica na formação ambiental de professores. Consideramos essa temática de extrema importância no campo da educação ambiental. Isso porque a mídia de massa se apresenta enquanto um importante espaço de produção de identidades e subjetividade principalmente dos jovens, tratando-se, portanto de um espaço de formação que vai muito além da informação.

No caso brasileiro é consensual que a maior parte da população recebe a informação a partir da mídia, sobretudo a televisiva. De acordo com Chauí (2006), o jornalismo investigativo cede lugar ao jornalismo assertativo ou opinativo, onde os fatos cederam lugar a declarações de "personalidades autorizadas", que não transmitem informações, mas preferências. Isso implica numa distorção da realidade, e consequentemente na manutenção dos interesses de alguns grupos em detrimento dos interesses coletivos, bem como na influência de comportamentos e opiniões individuais. Podemos identificar ainda nos discursos da mídia o deslocamento da responsabilidade de problemas ambientais para os indivíduos, silenciando os verdadeiros agentes produtores da destruição do meio ambiente. No lugar da crítica ao modelo capitalista de produção em seu atual estágio de desenvolvimento, enquanto o verdadeiro responsável das mazelas ambientais, a mídia de certa forma responsabiliza os indivíduos por tais problemas. É diante do paradoxo produzido pela mídia de massa, que ao mesmo tempo estimula o consumo e responsabiliza os sujeitos pela degradação ambiental, que os professores devem estar atentos.

Muitos programas que abordam a questão ambiental ainda se apresentam de forma espetacularizada, ou promovem o alarmismo. Tudo isso em busca de ganhar mais e mais audiência e consequentemente lucrar mais. Citando um exemplo, podemos destacar o programa Globo repórter exibido no dia 2/2/2014, onde o tema era o sumiço de Kivalina, uma vila com aproximadamente 400 moradores no Alasca, em virtude do aquecimento global. A reportagem mostrou as causas do desaparecimento da vila, mas em momento nenhum aponta os verdadeiros responsáveis por esse processo. Para a mídia, apontar as conseqüências de forma espetacularizada, é ainda mais importante do que fazer com que os sujeitos compreendam as suas causas.

O que se observa na atualidade é a predominância de um discurso midiático de caráter liberal que propõe alternativas sustentáveis que não esbarrem nos 
interesses do capital na sua produtividade. Além disso, podemos observar um novo mercado se constituindo em torno do argumento da sustentabilidade, ao ponto de haver especialista com livros publicados que tratam da "etiqueta ambiental". O livro eco chic - salvando o planeta com estilo é um exemplo dessa proposta enfadonha. A sinopse do livro destaca que adotar um estilo de vida eco chic significa - ser dona de um guarda-roupa matador; sentir-se maravilhosa; comer e beber do bom e do melhor; e sentir-se mais conectada aos seus amigos, familiares e à natureza. É incrível a contradição existente nessa perspectiva. Ser ecológico não é compatível com ter um guarda roupa matador. 


\section{5. Conclusões}

A questão ambiental se apresenta enquanto um tema complexo e urgente a ser amplamente investigado. Embora esteja sendo amplamente discutida em diferentes espaços de aprendizagem ainda não foi possível romper com o hiato que existe entre o discurso e a prática que orienta os sujeitos a uma sociedade saudável e equilibrada. Nesse sentido a educação ambiental crítica deve ser vista não mais como uma tendência dentro do campo ambiental, mas sim enquanto paradigma a ser adotado pela sociedade na tentativa de minimizar a chamada crise ambiental. A educação ambiental crítica não se refere a mais um modismo produzido por pseudoambientalistas que se arma de um discurso cínico de forma insolente que legitima a ampliação do capital.

Muito pelo contrário. Uma educação ambiental verdadeiramente crítica está implicada com a emancipação dos sujeitos, implicada com um olhar crítico de mundo, que objetiva desconstruir a lógica perversa que transforma cidadãos em meros consumistas, busca promover uma relação harmoniosa com a natureza e que respeita as comunidades tradicionais.

Ainda que a questão ambiental esteja fortemente presente no cotidiano seja por meio da mídia de massa, nos telejornais e documentários, a mesma ainda precisa ocupar um espaço maior no meio acadêmico. Assusta muito o silêncio de algumas áreas do conhecimento acerca do tema. Na geografia (minha formação inicial) os trabalhos que tratam do meio ambiente numa perspectiva crítica é quase que nulo. Infelizmente a geografia ainda não conseguiu superar a dicotomia geografia física - geografia humana. Em geral os trabalhos que se propõem a investigar as questões ambientais os fazem de uma forma descolada das questões sociais, políticas e econômicas, quando não se ocupam de compreender impactos ambientais tratando as relações sociais inerentes a esse processo de maneira superficial. Entretanto, deve-se destacar que essa é uma crítica construtiva e que parte de um olhar que conhece as causas dessa dicotomia. O que chamamos de geografia crítica ainda é algo muito recente e que pouco a pouco começa a dar sinais de um futuro promissor do campo.

Além disso, é possível perceber a necessidade de inserção da educação ambiental na formação inicial dentro das faculdades de formação de professores. 
Não somente nos cursos de pedagogia, mas em todas as áreas do conhecimento. Um tema transversal como é destacado nos documentos curriculares que orientam a educação nacional, deve ser visto de forma transversal. E nesse sentido, concordamos com a proposta de ser um tema transversal uma vez que a questão ambiental pode ser tratada de diferentes formas a partir de perspectivas distintas. Fazer da problemática ambiental objeto de estudo de uma única área do conhecimento é inviabilizar práticas capazes de romper com os prejuízos ambientais.

A partir da análise dos artigos foi possível notar que os mesmos se apresentam de maneira crítica segundo as categorias de análise utilizadas, bem como a compatibilidade com o referencial teórico aqui adotado. Os artigos se mostraram coerentes não havendo grandes contradições em seus discursos proferidos. Entretanto, a natureza do presente trabalho, um tanto desconfortável em alguns momentos, fizeram com que algumas limitações na produção intelectual investigada pudessem ser identificadas. Dentre essas limitações podemos apontar a ausência do esforço em utilizar os clássicos da literatura ambiental. Esse é um problema que vem crescendo em outras áreas do conhecimento principalmente em virtude do tempo cada vez mais reduzido em se desenvolver pesquisas. Ainda assim, acreditamos que esse é um esforço essencial na compreensão da questão aqui problematizada.

O trabalho também nos sugere que alguns conceitos não são profundamente discutidos sendo muitas vezes limitados a uma simples enunciação dos seus significados. Foi possível também perceber a existência de algumas discussões já superadas pelo campo, como por exemplo, a racionalidade técnica. Além disso, alguns trabalhos parecem fugir da proposta de uma educação ambiental crítica desenvolvendo questões que não são capazes de promover transformações reais. Nesse sentido, torna-se fundamental e necessário sair da zona de conforto e ultrapassar os limites da própria formação. Um educador ambiental crítico, deve estar ciente da sua necessidade constante de buscar um embasamento teórico capaz de nos fazer compreender a tão dinâmica questão ambiental.

Foi possível notar também que alguns trabalhos sugerem o diálogo entre os diferentes campos do conhecimento, mas sem aprofundar de fato a questão. A perspectiva Leffiana aponta a necessidade de promover um olhar complexo onde o intercâmbio de saberes deve ser contemplado, ao mesmo tempo em que sugere 
um olhar extremamente cuidadoso acerca da interdisciplinaridade. A interdisciplinaridade na concepção de Leff deve ser compreendida enquanto que uma necessidade de reorientar o conhecimento para apreender a unidade da realidade. Se de um lado já é sabido que a compartimentalização do conhecimento não promoveu o entendimento da totalidade do real, por outro o simples intercâmbio de saberes também não promove a reconstrução social. Essa percepção é fundamental para compreender o que o autor está chamando de epistemologia ambiental.

Espera-se que o presente trabalho seja capaz de contribuir no desenvolvimento de futuros estudos e estimule os demais pesquisadores na busca por uma sociedade mais justa do ponto de vista econômico, social, político e ambiental. $\mathrm{O}$ caráter inédito ${ }^{8}$ do trabalho sugere que a metodologia desenvolvida aqui possa ser aplicada em outras pesquisas, a fim de apontar possíveis equívocos e/ ou refutar as premissas aqui apresentadas e dessa forma contribuir para o desenvolvimento dessa pesquisa inicial.

A partir do desenvolvimento da presente dissertação e suas conclusões, espera-se que este trabalho possa oferecer alguma contribuição ao campo da educação ambiental. Este é apenas o primeiro passo para o aprofundamento na questão ambiental. $\mathrm{O}$ processo de produção do conhecimento deve ser compreendido enquanto uma espiral e é fundamental desenvolver o diálogo com outros autores, sem dispensar as importantes contribuições daqueles que há centenas de anos já apontavam para a atual crise em curso. Marx é o principal deles.

\footnotetext{
${ }^{8}$ Durante o desenvolvimento da presente pesquisa, não foram identificados trabalhos da mesma natureza. Foi possível identificar trabal hos que analisam artigos da ANPED, entretanto numa perspectiva diferenciada.
} 


\section{6. Referências bibliográficas}

AMORIM, M. L. de. Da evolução da concepção de natureza e de homem na ambivalência de uma educação ambiental crítica. Anais da $31^{\circ}$ Reunião anual da ANPEd, 2008.

ARROYO, M. G. Currículo, território em disputa. Petrópolis: Vozes, 2013.

BARCHI, R. Fundamentos da educação ambiental libertária. Anais da 30 ${ }^{\circ}$ Reunião anual da ANPEd, 2007.

BARRETO, M. P. Educação e Meio Ambiente: As possibilidades de uma utopia vermelha e verde. Anais da $33^{\circ}$ Reunião anual da ANPEd, 2010.

BOFF, L. Sustentabilidade: o que é e o que não é. Petrópolis: Vozes, 2012.

CARVALHO, I. C. de M. A pesquisa em educação ambiental: uma análise dos trabalhos apresentados na ANPED, ANPPAS e EPEA de 2001 a 2006. Pesquisa em educação ambiental, v. 3, n. 2, p. 147-174, 2008.

FERREIRA, D. P. As contribuições de temas socioambientais para a aprendizagem de matemática, sob os enfoques CTS, educação matemática crítica e educação ambiental. Rio de Janeiro, 2007, p.127. Mestrado acadêmico. Departamento de Ciência, Tecnologia e Educação Centro Federal de Educação Tecnológica Celso Suckow da Fonseca.

FERREIRA, N. Educação socioambiental de jovens e adultos: uma proposta crítico-emancipatória - presencial e a distância - de formação de professores. Anais da $30^{\circ}$ Reunião anual da ANPEd, 2008.

FLORIANO, M. D. Educação e meio ambiente na baixada fluminense: uma proposta de educação ambiental crítica numa escola municipal em Duque de Caxias - RJ. Rio de Janeiro, 2011, 111p. Mestrado profissional em ensino de Ciências. Instituto Federal de Educação, Ciência e Tecnologia do Rio de Janeiro.

FONSECA, J. R. B. da. Educação ambiental: uma experiência de sensibilização crítica para a ambiência na escola estadual José do Patrocínio. Amapá, 2011, 124p. Mestrado acadêmico em Direito Ambiental e Políticas Públicas. Universidade Federal do Amapá.

GARRIDO, L dos S. A percepção de meio ambiente por alunos do ensino fundamental com referência na educação ambiental crítica. Rio de Janeiro, 2012, 104p. Mestrado acadêmico em Ensino em Biociências e Saúde. Fundação Oswaldo Cruz.

GOMES, R. W. A geopolítica portuária do século XXI no município do Rio Grande: uma proposta de educação ambiental crítica/emancipatória. Rio Grande, 2012, 159p. Mestrado acadêmico em Educação Ambiental. Universidade Federal do Rio Grande.

GONÇALVES, J. C.; PORTO, C. W. Os (des)caminhos do meio ambiente. São Paulo: Contexto, 2013.

IARED , V. G.; TULLIO, A.; OLIVEIRA, H. T. de O. Uma aproximação entre Gadamer e Paulo Freire como contribuição para refletir sobre a pesquisa em educação. Anais da $35^{\circ}$ Reunião anual da ANPEd, 2012.

KAPLAN, L. Análise crítica dos discursos presentes nos documentos que definem a política de educação ambiental no Brasil. Rio de Janeiro, 2011, 369p. Mestrado acadêmico em Educação. Universidade Federal do Rio de Janeiro. 
LAYRARGUES, P. P. O cinismo da reciclagem: o significado ideológico da reciclagem da lata de alumínio e suas implicações para a educação ambiental. In: LAYRARGUES, P. P. (Org.) Educação ambiental: repensando o espaço da cidadania. São Paulo: Cortez, 2011.

LEFF, H. Epistemologia ambiental. São Paulo: Cortez, 2010.

LEFF, H. Ecologia, capital e cultura: A territorialização da racionalidade ambiental. Petrópolis: Vozes, 2009.

LEFF, H. Saber ambiental: sustentabilidade, racionalidade, complexidade e poder. Petrópolis: Vozes, 2008.

LOUREIRO, C. F. B. Premissas teóricas para uma educação ambiental transformadora. Ambiente e educação, Rio Grande, n. 8, p. 37-54, 2003.

LOUREIRO, C. F. B. O movimento ambientalista e o pensamento crítico: uma abordagem política. Rio de Janeiro: Quartet, 2003.

MAIA, J. S. da S. Educação ambiental crítica e formação de professores pesquisação escola pública processo grupal. Bauru, 2011, 250p. Doutorado em Educação para a Ciência. Universidade Estadual Paulista Júlio de Mesquita Filho.

MARIN, A. A.; SILVEIRA, E.; FILVOCK, S. F. Os desafios da educação ambiental diante da racionalidade técnica: diálogos com o pensamento crítico de Habermas. VII Seminário de Pesquisa em Educação da Região Sul. Itajaí, Santa Catarina, 2008.

MARX, K. O capital: crítica da economia política. Livro I: o processo de produção do capital. São Paulo: Boitempo, 2013.

MARX, K.; ENGELS, F. O manifesto comunista. Rio de Janeiro: Paz e Terra, 1998.

NUNES, A. R. da S. Educação ambiental crítica e sustentabilidade em portos na Amazônia: o programa de educação ambiental da Companhia Docas do Pará. ' Pará, 2012, 146p. Mestrado acadêmico em Educação. Universidade Federal do Pará.

OLABARRIAGA , N.; NEFFA, E. UERJ Formação de redes: uma dimensão pedagógica para a sustentabilidade. Anais da $33^{\circ}$ Reunião anual da ANPEd, 2010.

OLIVEIRA, A. L. de. A perspectiva participativa para a inserção da educação ambiental crítica em escolas da Baixada Fluminense. Rio de Janeiro, 2012, 143p. Mestrado acadêmico em Educação, Contextos Contemporâneos e Demandas Populares. Universidade Federal Rural do Rio de Janeiro.

OLIVEIRA, A. L. de. Discutindo a práxis participativa: concepções e contribuições à educação ambiental crítica da Baixada Fluminense. Anais da $35^{\circ}$

Reunião anual da ANPEd, 2012.

QUEIROZ , E. D. de. Caminhos para a inserção da dimensão socioambiental na formação inicial de educadores: possibilidades e obstáculos encontrados. Anais da $35^{\circ}$ Reunião anual da ANPEd, 2012.

RODRIGUES , J. do N. A imprescindível adoção da Teoria Crítica na formação do educador ambiental: um caminho para o enfrentamento da crise socioambiental e para a transformação da relação desigual HOMEM-SOCIEDADE-NATUREZA. Anais da $35^{\circ}$ Reunião anual da ANPEd, 2012.

ROHDE, M. D. S. Percepção dos problemas ambientais urbanos a partir do uso de mapas mentais: uma proposta de educação ambiental crítica/emancipatória em escola urbana de Rosário do Sul- 
RS. Santa Maria, 2012,111p. Mestrado acadêmico em Geografia. Universidade Federal de Santa Maria.

SANTOS, A. M. M. Ações socioambientais em uma comunidade cooperada: trabalho e conflito como categorias centrais na práxis. Anais da $33^{\circ}$ Reunião anual da ANPEd, 2010.

SANTOS, B. de S. Um discurso sobre as ciências. São Paulo: Cortez, 2010.

SANTOS, D. A. dos. Propaganda, consumo e sustentabilidade: uma análise narrativa da publicidade como aporte à educação ambiental crítica. Rio de Janeiro, 2011, 140p. Mestrado profissional em Ensino de Ciências. Instituto Federal de Educação, Ciência e Tecnologia do Rio de Janeiro.

SERRAO, M. A. Remando contra a maré: o desafio da educação ambiental crítica no licenciamento ambiental das atividades marítimas de óleo e gás no Brasil frente à nova sociabilidade da terceira via. Rio de Janeiro, 2012, 284p. Doutorado em Psicossociologia de Comunidade e Ecologia Social. Universidade Federal do Rio de Janeiro.

SILVA, R. L. F. Imagens e interpretações em educação ambiental. Anais da $31^{\circ}$ Reunião anual da ANPEd, 2008.

SILVA, R. L. F. A educação ambiental frente às mudanças climáticas globaiscontribuições da análise crítica da mídia. Anais da $36^{\circ}$ Reunião anual da ANPEd, 2013.

SINGH, R. A. A contribuição da geografia escolar para uma educação ambiental crítica e emancipatória: o caso do bairro Estoril de São Bernardo do Campo/ SP. São Paulo, 2012,117p. Mestrado acadêmico em Geografia. Pontifícia Universidade Católica de São Paulo.

SOARES, M. L. de A. Cidade, cotidiano, cidadania: um olhar ambiental. Anais da $29^{\circ}$ Reunião anual da ANPEd, 2006.

SOARES, M. L. de A. Entre a dupla determinação de homem e a revolução técnico-científica no campo da educação ambiental crítica. Anais da $32^{\circ}$ Reunião anual da ANPEd, 2009.

SOARES, M. L. de A. Entre as duas revoluções industriais mecânicas e a revolução bioengenharial no campo. Anais da $33^{\circ}$ Reunião anual da ANPEd, 2010.

SOUZA, P. C. M de. Educação ambiental crítica no cotidiano escolar: uma experiência na formação inicial de professores. Rio de Janeiro, 2012, 70p. Mestrado profissional em Ensino de Ciências. Instituto Federal de Educação, Ciência e Tecnologia do Rio de Janeiro.

SULAIMAN, S. N.; JACOBI, P. R. Os desafios e potencialidades da articulação entre educação ambiental e prevenção de desastres naturais no Brasil. Anais da $36^{\circ}$ Reunião anual da ANPEd, 2013.

TOZONI-REIS, M. F. de C. Fundamentos teóricos para uma pesquisa crítica da Educação Ambiental: algumas contribuições. Anais da $3^{\circ}$ Reunião anual da ANPEd, 2007.

VASCONCELLOS, M. das M. N.; QUEIROZ, G. R. P.; LOUREIRO, C. F. B. O trabalho cooperativo no enfrentamento dos limites que o tempo hegemônico impõe à prática de uma educação ambiental emancipatória. Anais da $3^{\circ}$ Reunião anual da ANPEd, 2012.

VASCONCELOS, V. S. de. A formação do sujeito ecológico por meio da educação ambiental crítica a partir de concepções pedagógicas Paulo Freireanas. Belo Horizonte, 2011, 105p. Mestrado Profissional. Pontifícia Universidade Católica de Minas Gerais. 